Zabytkoznawstwo i Konserwatorstwo XXXVIII, Toruń 2010

Alicja Saar-Kozłowska

Uniwersytet Mikołaja Kopernika w Toruniu

\title{
Problem autorstwa wyposażenia architektoniczno-rzeźbiarskiego \\ kaplicy Kołudzkich w katedrze w Gnieźnie Próba rozpoznania cech warsztatu*
}

\section{Wstęp}

Radania autorstwa dzieł należą do podstawowych zadań historyków Bztuki, ale też najtrudniejszych, a może najbardziej w gruncie rzeczy zaniedbanych. Wymagają - jak wiadomo - dokładnych studiów nad formą zabytku, wiedzy o historii jego powstania i sposobie wykonania, bardzo dobrej dokumentacji fotograficznej i rysunkowo-pomiarowej, starannych i wnikliwych oględzin oraz informacji o przeprowadzonych zabiegach konserwatorskich i dokonanych rekonstrukcjach. Szczególnych kłopotów nastręczają zabytki rzeźby - trudne do sfotografowania ze względu na warunki ekspozycji, przestrzenność bryły, oświetlenie; trudne do porównywania z uwagi na zmienność widoków oraz niełatwy do spełnienia wymóg dysponowania

* Problem ten zostal jedynie w skromnym zakresie poruszony w referacie „Kwestia autorstwa pomnika grobowego Anny Wazówny" wygłoszonym podczas sesji poświęconej pamięci Profesor Jadwigi Puciata-Pawłowskiej, zorganizowanej przez Toruński Oddział Stowarzyszenia Historyków Sztuki oraz Instytut Zabytkoznawstwa i Konserwatorstwa Uniwersytetu Mikołaja Kopernika w Toruniu w grudniu 2002 r. Kaplicy Kołudzkich dotyczył w całości także niepublikowany referat wygłoszony na sesji naukowej poświęconej pamięci Profesora Gwidona Chmarzyńskiego, zorganizowanej przez Toruński Oddział SHS w grudniu 2003 r. pt. „Kaplica Kołudzkich w Gnieźnie - problem autorstwa”. 
w dokumentacji fotograficznej analogicznymi ujęciami; wymagające szczególnych zabiegów mających na celu stworzenie możliwości bezpośredniego oglądu.

Niestety, trzeba przyznać, że w naszej historii sztuki zbyt często atrybucje zaproponowane w dziedzinie rzeźby są dokonywane, jak się okazuje, szybko i powierzchownie, nieraz na podstawie spostrzeżeń dotyczących zastosowanych motywów i ogólnych cech kompozycji traktowanej płaszczyznowo, a nie szczegółowej analizy kwestii tak dla rzeźby istotnych, jak: kompozycja przestrzenna, opracowanie detali architektonicznych i ornamentalnych oraz detali figur, a także techniczny sposób wykonania. Czasem zdarza się, że sprawę rozwiązują źródła, ale tylko pod warunkiem, że są one poprawnie interpretowane.

Poważnych kłopotów atrybucyjnych nastręczają zabytki rzeźby polskiej XVII wieku, a wśród nich również te z kaplicy Kołudzkich (il. 1-5), które są niemal nieopracowane w literaturze przedmiotu i słabo reprodukowane, a w związku z tym także prawie całkowicie pomijane w rozważaniach porównawczych. Autorstwo wyposażenia kaplicy i wiodącego do niej portalu nie znalazło jak dotąd potwierdzenia źródłowego. W literaturze przedmiotu było ono przypisywane dwóm znaczącym postaciom sztuki rzeźbiarskiej na ziemiach polskich w XVII wieku: Sebastianowi Sali lub Wilhelmowi Richterowi, reprezentującym - jak się zwykło uważać - dwie odmienne orientacje w dziejach rzeźby polskiej.

Sebastianowi Sali lub warsztatom dębnickim przypisała autorstwo wyposażenia kaplicy Kołudzkich Aniela Sławska w roku 1958 i atrybucję tę podtrzymała w roku 1965․․ Opinię tę przejął także Włodzimierz Dworzaczek, który twierdził, że kaplica być może powstała w „jakimś związku z warsztatem Sali”². Karolina Targosz w 1962 roku (publikacja 1991) w nawiązaniu

$1 \quad$ [A. S.] A. Sławska, [w:] E. Kręlewska-Foksowicz, E. Linette, J. Powidzki, A. Sławska, Sztuka baroku w Wielkopolsce, „Biuletyn Historii Sztuki”, R. 20: 1958, s. 61; A. Sławska, Barok, w rozdziale: H. Kozakiewiczowa, A. Sławska, Życie kulturalne Gniezna XVI-XVIII w., [w:] Dzieje Gniezna, pod red. J. Topolskiego, Warszawa 1965, s. 410. Sławska dopatrywała się też związku wyposażenia kaplicy z wawelską kaplicą Batorego.

2 W. Dworzaczek, Kotudzki Szymon h. Pomian, [w:] Polski stownik biograficzny, t. 13, Wrocław-Warszawa-Kraków 1967-1968, s. 366. 
do opinii Sławskiej stwierdziła, że bardziej prawdopodobna wydaje się jej możliwość łączenia autorstwa kaplicy z „fabryką” dębnicką niż z warsztatem Sali, ze względu na niższy poziom jej wykonania w porównaniu z dziełami wspomnianego rzeźbiarza ${ }^{3}$. Kazimierz Kuczman w biogramie Sebastiana Sali zamieszczonym w roku 1993 w Polskim słowniku biograficznym wymienia „architekturę i wystrój rzeźbiarski” kaplicy jako dzieło, które rzeźbiarzowi przypisywano ${ }^{4}$.

Już w 1855 roku Józef Walkowski, a za nim Ignacy Polkowski w 1874, na podstawie bliżej nieznanych nam przesłanek sądzili, że twórcy wyposażenia zabytku należy szukać wśród rzeźbiarzy gdańskich ${ }^{5}$. Zdaniem Lecha Krzyżanowskiego, który jak dotąd najwięcej uwagi poświęcił interesującemu nas zabytkowi w zbiorowym opracowaniu dotyczącym katedry gnieźnieńskiej (1970), opinie wspomnianych badaczy potwierdza „w całej rozciąłłości” analiza stylistyczna ${ }^{6}$. Badacz ten wyraził pogląd, że portal, podobnie jak i pozostała część plastyki kaplicy Kołudzkich, „mógł wyjść z warsztatu Wilhelma Richtera, który wykonał szereg innych portali” w katedrze, co zostało ustalone w toku badań źródłowych prowadzonych w związku z przygotowaniem wspomnianej monografii.

3 K. Targosz, Kaplica biskupa Jakuba Zadzika w katedrze na Wawelu i jej architekt Sebastian Sala, „Studia do Dziejów Wawelu”, 1991, t. 5, s. 279. Jest to publikacja pracy magisterskiej autorki, która została napisana w roku 1962 na Wydziale Filozoficzno-Historycznym Uniwersytetu Jagiellońskiego i wówczas oddana do druku. Tekst ukazał się w roku 1991 bez zmian i - jak pisze autorka - bez uwzględnienia późniejszego stanu badań.

4 K. Kuczman, Sala Sebastian, [w:] Polski słownik biograficzny, t. 34, Wrocław-Warszawa-Kraków 1992-1993, s. 351.

5 J. Walkowski, Wspomnienie o kościele metropolitalnym $w$ Gnieźnie, o jego ołtarzach, kaplicach, pomnikach i osobach temi pomnikami zaszczyconych... napisane w 1865 r., Gniezno 1876, s. 202-203; I. Polkowski, Katedra Gnieźnieńska, Gniezno 1874, s. 61.

6 LK [L. Krzyżanowski], Portal kaplicy Kołudzkich, [w:] Katedra Gnieźnieńska, t. 1, pod red. A. Świechowskiej, Poznań-Warszawa-Lublin 1970, s. 310. W odniesieniu do portali w arkadach prezbiterium autorstwa Richtera badacz wskazał na charakterystyczne cechy gdańskich warsztatów rzeźbiarskich zauważalne już od połowy XVI w., takie jak: „Manierystyczny charakter kompozycji unikającej akcentów architektury klasycznej w dolnej części, wielobarwna kompozycja wątków kamienia i drobne motywy ornamentalne - kaboszony, szyszki, kule" (idem, Portale w arkadach prezbiterium, [w:] ibidem, s. 309). 
Lech Krzyżanowski sądził, że jakość plastyki figuralnej całej kaplicy Kołudzkich (portal i wnętrze) jest lepsza aniżeli w pozostałych portalach tego warsztatu, co nie jest - zdaniem badacza - istotnym argumentem w kwestii atrybucji. Fakt ten tłumaczył tym, że w odziedziczonym po Abrahamie van den Blocku największym w Gdańsku warsztacie Wilhelm Richter był raczej kierownikiem tego przedsiębiorstwa, podobnie jak wcześniej Abraham. Dlatego też - pisał - „charakter plastyki figuralnej [...] zależał od umiejętności czeladnika" wykonującego powierzoną pracę. Krzyżanowski zauważył też, że w ołtarzu występują anachroniczne już w dobie baroku detale dekoracji manierystycznej, takie jak: „forma uszu, motyw przecięcia uszu i pilastrów w tle kolumn wspólną listwą występującą przed lico, kształt występu, na którym osadzony jest kartusz herbowy". W strukturze ołtarza dostrzegał spokój pomimo silnego występowania gzymsów oraz kontrastowych akcentów ${ }^{8}$, tektonikę barokowych form i ograniczenie ozdób. Jako istotną cechę ołtarza potraktował to, że został on skomponowany jednocześnie z organizacją całego wnętrza kaplicy, stając się jej nieodłącznym składnikiem9. Plastykę figuralną ołtarza badacz uznał za jego „silną stronę”. W przypadku rzeźb apostołów wskazywał na samodzielność realizacji rzeźby, ożywienie ich kontrapostem oraz indywidualne potraktowanie pełnych wyrazu głów. Krzyżanowski akcentował też "charakterystyczny” dobry poziom rzeźb aniołków ze zwieńczenia, które uznał za podobne do tych zdobiących portal, i przypominał, że gdańskie warsztaty elementy znajdujące się wyżej i słabiej widoczne opracowywały mniej starannie. Główki puttów predelli autor określił jako zindywidualizowane i stwierdził, że są one świadectwem troski o detal ${ }^{10}$.

Janusz Pałubicki w swojej pracy magisterskiej ${ }^{11}$ poparł atrybucję ołtarza i portalu kaplicy Kołudzkich Richterowi, dokonaną przez Krzyżanowskiego, i w tym celu wskazał „dwa podobne obiekty z Prus Królewskich: nagrobek

7 Idem, Portale w arkadach, s. 310-311.

8 Idem, Ottarz w kaplicy Kołudzkich, [w:] Katedra Gnieźnieńska, s. 291.

9 Idem, Ottarze, [w:] ibidem, s. 287.

10 Idem, Ottarz w kaplicy Kołudzkich, s. 291.

11 J. Pałubicki, Marmurowa rzeźba architektoniczna Prus Królewskich w XVII wieku, Poznań 1973, praca magisterska napisana na Uniwersytecie Adama Mickiewicza w Poznaniu, maszynopis, s. $74-75$. 
Anny Wazówny z 1636 r. [...] i ołtarz Opłakiwania w kościele św. Mikołaja w Gdańsku z 1662 r.” Do dodania tych dwóch obiektów do twórczości Richtera upoważniały autora następujące cechy: „identyczne rozwiązania konstrukcji, podobieństwo górnych partii, te same wieloboczne plakiety, które znamy z portali w prezbiterium gnieźnieńskim, a zarazem słaba rzeźba figuralna".

W biografii Richtera zamieszczonej w Polskim słowniku biograficznym opublikowanym w 1988 roku Pałubicki wymienił ołtarz kaplicy Kołudzkich wśród dzieł przypisywanych rzeźbiarzowi ${ }^{12}$, obok takich realizacji, jak: nagrobek biskupa Adama Nowodworskiego w katedrze poznańskiej (wykonany w 1634 roku), ołtarze Zwiastowania (1635) i św. Józefa (1637) w kościele Cystersów w Oliwie, a także dekoracja rzeźbiarska fasady i portalu kamienicy przy ulicy Piwnej 1 w Gdańsku (ukończona w 1640 roku).

Janusz Pałubicki pisał też, „że rzeźba w warsztacie Richtera była dekoracyjnym, nie zawsze zręcznym uzupełnieniem architektury, trochę schematyczna i umownie tylko związana z otoczeniem”. Zdaniem badacza architektoniczno-rzeźbiarskie dzieła wykonywane w warsztacie były liczne, a te zachowane do dziś ${ }^{13}$ są „ dobrej przeciętnej miary cechowej, bez nowatorskich koncepcji”. Prace te trafiały do ówczesnych gustów dzięki tradycyjności form architektonicznych i rzeźbiarskich oraz starannemu wykonaniu.

Pytanie o autorstwo kaplicy Kołudzkich w katedrze w Gnieźnie nie ogranicza się tylko do interesującego nas zabytku, ale tak jak każda próba hipotezy atrybucyjnej jest także podjęciem na nowo podstawowych, szerszych - a wykraczających poza zakres tej wypowiedzi - problemów dotyczących historii sztuki rzeźbiarskiej i architektonicznej w Polsce w pierwszej i wkrótce po połowie XVII wieku, a wśród nich takich kwestii, jak:

- oeuvre tej klasy artystów co Sebastian Sala i Wilhelm Richter,

12 Idem, Richter Wilhelm, [w:] Polski słownik biograficzny, t. 31, Warszawa-Kraków-Gdańsk-Łódź 1988, s. 285.

13 Ibidem, s. 285. Można się zastanawiać, czy chodzi o dzieła znane w literaturze przedmiotu jako potwierdzone źródłowo (4 portale gnieźnieńskie), czy też o dzieła przypisywane Richterowi. 
- odrębność lub wzajemne przemieszanie motywów zaczerpniętych ze sztuki włoskiej i niderlandzkiej ${ }^{14}$,

- indywidualny styl artysty z jednej strony, a z drugiej powszechność motywów, form rzeźbiarskich, architektonicznych i zdobniczych oraz tematów w kategoriach tzw. stylu epoki.

Wznowienie dyskusji nad autorstwem jednego dzieła jest niemalże automatycznie pobudzeniem pytań o autorstwo innych, jest także zachętą do zmian atrybucyjnych, rewizji, ustawienia nowych ciągów dzieł pokrewnych.

Poruszając problem atrybucji wyposażenia kaplicy Kołudzkich, nie sposób nie wziąć pod uwage, oprócz wnętrza i portalu kaplicy oraz czterech portali katedry przypisywanych Wilhelmowi Richterowi (zob. fragment jednego z nich, il. 42), nagrobka biskupa Wawrzyńca Gembickiego atrybuowanego Sebastianowi Sali, znajdującego się w świątyni, w osobnej kaplicy, a szczególnie monumentu Piotra Opalińskiego w Sierakowie, będącego źródłowo potwierdzonym dziełem Sali ${ }^{15}$, pomnika grobowego Anny Wazówny (fragmenty il. 44, 45) jako tego, który próbowano łączyć nie tylko z warsztatem Abrahama van den Blocka ${ }^{16}$, ale także $\mathrm{z}$ Richterem (Pałubicki) ${ }^{17}$ oraz z osadzonym w nurcie niderlandzkim „Mistrzem nagrobka Nowodworskie-

14 M. Karpowicz (Chronologia i geografia niderlandyzmu w rzeźbie 1. połowy XVII wieku, [w:] Niderlandyzm na Ślasku i w krajach ościennych, pod red. M. Kapustki, A. Kozieła i P. Oszczanowskiego, Wrocław 2003, s. 43-44) zwrócił uwagę na fakt, że istniejące za czasów Zygmunta III wyraźne granice między trzema głównymi nurtami sztuki na ziemiach polskich - włoskim, niderlandzkim i rodzimym - za czasów Władysława IV uległy „powolnemu zatarciu", co spowodowało upodobnienie się całej produkcji artystycznej.

15 Zob. S. Wiliński, Rzeźby Sebastiana Sali dla Krzysztofa Opalińskiego, „Biuletyn Historii Sztuki”, R. 18: 1956, s. 55-83.

16 Jako pierwszy atrybucję te zaproponował B. Makowski, Sztuka na Pomorzu. Jej dzieje izabytki, Toruń 1932, s. 161.

17 J. Pałubicki, Nagrobek Ernesta Bogusława księcia Croy w kościele św. Jacka w Stupsku i jego twórca Hans Caspar Gockheller z Gdańska, [w:] Ars una. Prace z historii sztuki (Uniwersytet im. Adama Mickiewicza w Poznaniu, seria „Historia Sztuki”, nr 4), pod red. E. Iwanoyki, Poznań 1976, s. 131, przyp. 14. W haśle poświęconym Richterowi w Polskim stowniku biograficznym autor nie powtórzył już tej atrybucji. 
go" (Karpowicz, jedynie portal ze znakiem zapytania ${ }^{18}$, nagrobek również ze znakiem zapytania określony jako dzieło Giovanniego Battisty Falconiego ${ }^{19}$ ), a który - według naszych badań - można próbować sytuować w zakreślonym tu kręgu poszukiwań atrybucyjnych, co - jak zaświadcza stan badań - sugerował już wcześniej Janusz Pałubicki ${ }^{20}$.

Prace dokumentacyjne i studia, które można i należy przeprowadzić w kwestii poszukiwań atrybucyjnych w przypadku kaplicy Kołudzkich, są jakby próbą spełnienia tego, co należy zrobić w odniesieniu do bardzo wielu zabytków sztuki polskiej. Okazuje się, że opublikowane uwagi są często tak syntetyczne lub oparte na tak nikłych przesłankach, że trudno wysnuwać na ich podstawie dalsze wnioski dotyczące autorstwa innych zabytków oraz prowadzić analizy porównawcze. Dodatkowo prace komplikuje lub - bez podjęcia wysiłku ponownego dokumentowania - wręcz uniemożliwia tendencja do minimalizowania i ujednolicania liczby ilustracji w publikacjach, często także poświęconych kwestiom warsztatowym.

18 M. Karpowicz, Chronologia i geografia. Badacz stwierdzil, że militarna blokada Gdańska spowodowana wojną ze Szwecją wywołała też jego blokadę artystyczną, która to predystynowała środowisko poznańskie do zajęcia głównego miejsca na mapie niderlandyzmu w Polsce. „Pierwszą uchwytną, ważną postacią tego środowiska jest «Mistrz nagrobka Nowodworskiego»" (s. 49). Wypowiedź Mariusza Karpowicza znacznie wzbogaca i różnicuje obraz sztuki polskiej XVII w. Autor uznał, że bliski twórczości „Mistrza nagrobka Nowodworskiego” jest portal pomnika grobowego Anny Wazówny w kościele Wniebowzięcia Najświętszej Panny Marii w Toruniu (s. 50). Dotychczas nagrobek Nowodworskiego (zm. 1634) był przypisywany Richterowi. Zob. J. Pałubicki, Richter Wilhelm, s. 285.

19 M. Karpowicz, Artisti Ticinesi in Polonia nella prima meta'del'600, Ticino 2002, s. 199.

20 W odniesieniu do pomnika grobowego Wazówny także wysuwano różnorodne hipotezy dotyczące zaangażowania wykonawców z odmiennych środowisk artystycznych. Oprócz artystów o orientacji północnej wskazywano także na udział Constantina Tencali (W. Tomkiewicz, Z dziejów polskiego mecenatu artystycznego w w. XVII. Źródła do dziejów sztuki polskiej, t. 4, red. A. Ryszkiewicz, Wrocław 1952, s. 33, projekt architektoniczny) oraz Giovanniego Gisleniego (Z. Rewski, Sesja Naukowa Stowarzyszenia Historyków Sztuki poświęcona sztuce Warmii i Pomorza Wschodniego, Olsztyn 19 IX, Toruń 22-23 IX 1955, kronika Stowarzyszenia Historyków Sztuki, „Biuletyn Historii Sztuki”, R. 18: 1956, nr 1, s. 189). 


\section{Prezentacja zabytku}

\section{Fundacja i datowanie}

Portal oraz całe wyposażenie kaplicy zostało ufundowane przez księdza kanonika i proboszcza metropolitalnego Szymona Kołudzkiego ${ }^{21}$ (il. 1-5).

Datowanie wyposażenia kaplicy nie jest dokładne. W napisie fundacyjnym, wykutym zapewne w ścianie wyłożonej już czarnym marmurem, wymieniona jest data 1652, lecz wiadomo, że jeszcze w 1659 roku trwały jakieś prace związane z wykańczaniem kaplicy. W źródłach dotyczących innych portali ten prowadzacy do kaplicy Kołudzkich jest wymieniany jako istniejący już w roku 165322. W Katalogu zabytków sztuki zaproponowano datowanie wyposażenia wnętrza i portalu wiodącego do kaplicy na czas około $1647 \mathrm{roku}^{23}$. Wówczas to Szymon Kołudzki, za pieniądze pochodzące ze sprzedaży bratu Stanisławowi swego majątku (za sumę 85000 zł) - jak podaje Włodzimierz Dworzaczek - oraz dochody płynące z kumulacji bogatych beneficjów, przeprowadził gruntowną restaurację kaplicy Dryjów, a na jej utrzymanie przeznaczył dobra skupione przez siebie w latach 1644-1649 o łącznej wartości 93000 złotych²4. Lech Krzyżanowski proponuje przyjąć jako „najbezpieczniejsze datowanie” lata przed 1652 rokiem, zgodnie z data zawartą w napisie fundacyjnym ${ }^{25}$ (il. 5), o ołtarzu zaś pisze, że został wykonany nie później niż w roku $1656^{26}$.

21 LK [L. Krzyżanowski], Portal kaplicy Kołudzkich, s. 309-310.

22 Ibidem, s. 310; K. Targosz (op. cit., s. 279), za A. Sławską (Barok, s. 410), twierdzi, że kaplica Kołudzkich została wyposażona około roku 1647 w epitafium, ołtarz i portal. Odpis legendy epitafijnej za Polkowskim zamieszcza LK [L. Krzyżanowski] w pracy zbiorowej: Katedra Gnieźnieńska, s. 256, na temat lawy i pulpitu zob. s. 356, na temat świeczników s. 400-401, na temat płyty nagrobnej Szymona Kołudzkiego s. 241.

23 Katalog zabytków sztuki, t. 5: Województwo poznańskie, pod red. T. Ruszczyńskiej i A. Sławskiej, z. 3: Powiat gnieźnieński, Warszawa 1963, s. 29, il. 87, 122.

24 W. Dworzaczek, op. cit., s. 366.

25 LK [L. Krzyżanowski], Portal kaplicy Kołudzkich, s. 310.

26 Idem, Ottarz w kaplicy Kołudzkich, s. 290. 
Kaplica była restaurowana w latach $1740-1746^{27}$ oraz 1999-2000 (wyposażenie marmurowo-alabastrowe oraz malowidła sklepienia ${ }^{28}$, widoczne we fragmencie na il. 3).

\section{Architektura kaplicy}

Kaplica Kołudzkich w katedrze w Gnieźnie jest usytuowana przy obejściu katedry. Jest to jedna z czternastu kaplic. Przylega od strony południowej do najbardziej wysuniętej na wschód, umieszczonej na osi świątyni, kaplicy Niepokalanego Poczęcia NP Marii (Gembickiego). Powstała z przebudowy XIV-wiecznej kaplicy zwanej Dryja. Jest zbudowana na planie trapezu, przykryta sklepieniem kolebkowym z lunetami. Na poddaszu zachowały się ślady sklepienia krzyżowo-żebrowego. Ma jedno okno (il. 1), na zewnątrz ujęte dekoracyjnym obramowaniem z piaskowca z herbem Pomian i literami SK [Szymon Kołudzki]. Mierzy ona obecnie około 8 metrów wysokości i jest włączona w ciag kaplic otaczających korpus nawowy i ambit katedry, przykrytych wspólnym spadzistym dachem, zbudowanym nad obejściem i kaplicami. Pierwotna kaplica była niższa (mierzyła około 6 metrów) i prawdopodobnie od strony zewnętrznej wieloboczna (trzy boki sześcioboku) ${ }^{29}$. Jej forma architektoniczna oraz zespolenie z korpusem katedry są interpretowane jako efekt prac budowlanych prowadzonych za czasów biskupa Macieja Łubieńskiego (1641-1652). Przebudowano wówczas w stylu barokowym szereg kaplic, nakryto wspólnym dachem nawy, ambit i wieniec kaplic, zbarokizowano wnętrze, a na skutek tego m.in. cześciowo zamurowano gotyckie arkady wiodące do kaplic, a także z prezbiterium do ambitu oraz osadzono barokowe portale ${ }^{30}$.

27 Katalog zabytków sztuki, s. 29.

28 P. Niemcewicz, M. Norkowski, Dokumentacja konserwatorska, Ołtarz i wykładzina kamienna ścian w kaplicy Kołudzkich, II poł. XVII-II poł. XVIII w., katedra w Gnieźnie, Toruń 1999, maszynopis; iidem, Dokumentacja konserwatorska, Posadzka i ławy marmurowe z kaplicy Kołudzkich, II poł. XVII w., Toruń 2001, maszynopis.

29 J. Zachwatowicz, Architektura katedry gotyckiej, [w:] Katedra Gnieźnieńska, s. 50.

30 Katalog zabytków sztuki, s. 13. 
Do kaplicy prowadzi portal o formie charakterystycznej dla zespołu wczesnobarokowych portali katedry gnieźnieńskiej (il. 1). Zamknięty półkoliście otwór wejściowy flankują dwie wąskie lizeny, dźwigające wydatne belkowanie, na którym został osadzony naczółek z plastyką figuralną oraz z herbem Pomian. Wejście do kaplicy zamyka ozdobna żelazna krata.

\section{Wnętrze kaplicy i jej wyposażenie}

\section{Materiał}

Ściany kaplicy są trójbarwne (il. 2-5). Zostały wyłożone czarnym marmurem $^{31}$ (il. 2-5, 34, 36), z niego też wykonano elementy konstrukcji i tło ołtarza (il. 2, 3, 35) oraz ławy (fragment il. 5), a także narożne pilastry (il. 5). Marmurem w brązowym kolorze o dwu odcieniach podkreślono podsklepienne łuki ścian (il. 3, 25, 26), zarys okna, cokół podłogi (il. 2), płytę mensy (il. 2), w późniejszym czasie dodano też brązowe antependium (il. 2). Marmurem białoszarym plamistym zostało obramowane czoło mensy (il. 2). Z białego alabastru wykonano rzeźby pełnoplastyczne i płaskorzeźby oraz elementy detalu architektonicznego - bazy (il. 2, 3, 8), kapitele (il. 43), konsole pod

31 P. Niemcewicz (Konserwacja wapienia dębnickiego, Toruń 2005, s. 32, i1. 16, s. 37) określił marmur użyty w kaplicy Kołudzkich jako dębnicki, przypomniał jednakże opinię A. Miłobęzkiego (Czarny marmur, [w:] Architektura polska XVII wieku (Dzieje sztuki polskiej, t. 4, cz. 1: Sztuka polska XVII wieku), Warszawa 1980, s. 218), dotyczącą zastosowania w gnieźnieńskiej katedrze także marmurów pochodzenia belgijskiego. Miłobędzki stwierdził, że w katedrze w Gnieźnie, tak jak i na Wawelu, mała architektura wykonana z czarnego marmuru jest „przykładem wejścia” jej do „starszego organizmu budowlanego, ale w Gnieźnie większość czarnomarmurowych portali jest dziełem warsztatów gdańskich i wykonano je w materiale pochodzącym nie z Dębnika, ale z kamieniołomów na obszarze dzisiejszej Belgii”. Podobną opinię dotyczącą wykorzystania w katedrze gnieźnieńskiej marmurów belgijskich wyraził wcześniej L. Krzyżanowski (Portale, s. 304), który stwierdzając, że „gdańszczanie swoje marmury sprowadzali z Belgii”, powołał się na korespondencję związaną z fundacją portalu Matki Boskiej Częstochowskiej, która dowodzi, że jego wykonawca, gdański rzeźbiarz Jan Kacper Alschmann, sprowadzał marmury właśnie z Belgii. Ostatnio M. Wardzyński (Marmury i wapienie południowoniderlandzkie na ziemiach polskich od średniowiecza do 2 poł. XVIII w. Import $i$ zastosowanie $w$ małej architekturze i rzeźbie kamiennej, „Biuletyn Historii Sztuki”, R. 70: 2008, nr 4, s. 352) wymienił okładzinę wnętrza i ołtarz kaplicy Kołudzkich wśród dzieł wykonanych z marmurów południowoniderlandzkich. 
uszakami ołtarza (il. 23) oraz inne elementy dekoracyjne ${ }^{32}$. Akcenty bieli na czarnym tle gnieźnieńskiego ołtarza są dość znaczne i może zbyt silnie rozbijają jego monolit (il. 2-3). Bardziej elegancko wyglądają elementy białych tkanin podwieszonych na tle czarnych ścian (il. 4-5).

\section{Opis}

Na wschodniej ścianie kaplicy znajduje się barokowy przyścienny ołtarz architektoniczny, skomponowany jednocześnie z organizacją całego wnętrza (il. 2-4). Ma on wysoki cokół związany ze stołem ołtarzowym, na którym wspiera się kolumnowa nastawa. Partia cokołowa kolumn i przestrzeń pomiędzy nimi oraz narożne konsolki tworzą predellę, zdobioną w polu środkowym motywem chusty świętej Weroniki (il. 6) oraz uskrzydlonymi głowami puttów (il. 2, 7, 8). Powyżej, między kolumnami, wewnątrz profilowanej ramy z uszakami, znajduje się rzeźba Chrystusa ukrzyżowanego (il. 2, 9-11), a poza nią u góry Arma Christi - pęki rózg i bicze (il. 2, 12). Boki nastawy ujmują okazałe uszaki zwieńczone szyszakami, z półkoliście zamkniętymi niszami, o krawędziach zdobionych wolutami (il. 2, 13, 18), na tle których stoją postacie apostołów Piotra i Pawła, pozbawione innych atrybutów poza ksieggami i fragmentami kwadratowych kamieni pod stopami (il. 13-22) ${ }^{33}$.

Kolumny nastawy dźwigają odcinki belkowania i gzyms oraz półkola rozerwanego naczółka (il. 2, 3, 24, 25, 27, 35), na którym zostały osadzone uskrzydlone aniołki (il. 24-27).

32 Por. LK [L. Krzyżanowski], Ottarz w kaplicy Kołudzkich, s. 290.

33 Zdaniem Lecha Krzyżanowskiego (Ottarz w kaplicy Kołudzkich, s. 290) inne atrybuty zaginęły. Krzyżanowski (ibidem, il. 208, zdjęcie z uszkodzoną dłonią) apostoła po lewej określa jako św. Piotra (w niniejszym artykule il. 13-17). Z uwagi na układ postaci w ołtarzach o analogicznej ikonografii identyfikację tę należy przyjąć. Zob. np. ołtarz główny w kościele św. Katarzyny w Golubiu z roku 1640, ilustracja [w:] R. Sulewska, Dłutem wycięte. Snycerstwo pótnocnych ziem polskich w czasach Zygmunta III Wazy, Warszawa 2004, s. 222, oraz il. 194 na s. 362, il. 196 na s. 363 (św. Piotr). Figury św. Piotra z Golubia oraz z Gniezna znajdują się w niszach, mają podobny układ ciała. Stoją w kontrapoście. W jednej wyprostowanej ręce trzymają księge, w drugiej zgiętej atrybut (w Gnieźnie zaginiony) - klucze. Obie postacie odziane są w długą spodnią tunikę, przewiązaną w talii, i spięty pod szyją, opadający na ramiona płaszcz. 
Pole środkowe wypełnia tablica z wyobrażeniem Chrystusa zmartwychwstałego (il. 28-33). Ponad nią w otoczeniu wolutowych motywów ozdobnych widnieje herb Pomian (il. 3). Po bokach ołtarza, pod gzymsem, znajduja się alabastrowe girlandy owocowo-listne zawieszone na chustach (il. 3, 34), a na ścianach północnej i południowej alabastrowe chusty (il. 4, 5, 36).

$\mathrm{Na}$ podłodze, pokrytej posadzką z czarno-białych flizów ułożonych w ukośną szachownicę (il. 2), w wejściu do kaplicy znajduje się płyta nagrobna z herbem Pomian i literami SK [Szymon Kołudzki].

Po stronie zachodniej została umieszczona tablica fundacyjna, składająca się z wykutego wprost na ścianie napisu powstałego w 1652 roku, późniejszego metalowego obramowania ornamentalnego z portretem Szymona Kołudzkiego dodanego po śmierci fundatora (1656) oraz z kompozycji herbowej malowanej na blasze ${ }^{34}$ (il. 5). Poniżej tablicy fundacyjnej, pod gzymsem wieńczącym ścianę kaplicy, znajduje się inskrypcyjne epitafium Szymona Kołudzkiego, otoczone dekoracyjną ramą wykonaną z blachy miedzianej. Metaloplastyczne elementy obramienia tablicy fundacyjnej i epitafium sa łączone z warsztatem złotnika toruńskiego Bierpfaffa, portret zaś ze środowiskiem gdańskim ${ }^{35}$ (il. 5).

Uzupełnieniem wyposażenia kaplicy jest barokowa ława znajdująca się pod ścianami południową i zachodnią (fragment widoczny na il. 5), wykonana z czarnego i brązowego marmuru, fundowana przez Szymona Kołudzkiego, złożona z siedziska wspartego na trzech wolutowych konsolach i usytuowanego przed nim pulpitu ${ }^{36}$.

34 Tekst napisu jest nastepujący: D. O. M. / MATRI VIRGINI / CHRISTI FILII EIVS PASSIONI / SACELLUM HOC / ORNAVIT ET DOTAVIT / RN ${ }^{S}$ SIMON KOLVDZKI PRAEPS. HVIVS ECCLAE /\&C. \&C. S. R. M. SECRETARI / ANNO SALUTIS / M. D. C. L. I I / VIATOR VIVENTI LONGAEVAM / MORTVO AETERNAM VITAM / PRECARE. Cyt. za: L. Krzyżanowski, Tablica fundacyjna kaplicy Kołudzkich, [w:] Katedra Gnieźnieńska, s. 255.

35 Idem, Epitafium Szymona Koludzkiego, kanonika i proboszcza metropolitalnego, zm. 1656, [w:] Katedra Gnieźnieńska, s. 256-257. Tam pełny tekst legendy epitafijnej cytowany za Polkowskim.

36 Do wyposażenia kaplicy należy także barokowy, drewniany, malowany na czarno pulpit z pierwszej połowy XVIII w. oraz para srebrnych świeczników wykonanych przez Andrzeja Mackensena I, pozostałych z 6 fundowanych przez Szymona Kołudzkiego. Por. L. Krzyżanowski, Katedra Gnieźnieńska, s. 356, 400-401. 
W XVIII wieku Andrzej Kołudzki, kanonik gnieźnieński, ufundował antependium zdobione herbem Pomian z kapeluszem kanonickim i datą 1756 oraz literami A[ndresas] K[ołudzki] C[anonicus] G[nesnensis], a także P R w środku cyfr daty (zob. il. 2).

Nieznanego autorstwa malowidła, o iluzjonistycznie przedstawionym okulusie z balustradą otwierającym się na niebo, znajdujące się na sklepieniu kaplicy Kołudzkich, powstały w XVIII wieku (fragment il. 3). Wyobrażaja one personifikację czterech cześci świata oddających hołd Bogu Ojcu ${ }^{37}$ (fragment il. 3, 24, 27). Nieznana jest pierwotna dekoracja sklepienia.

Zdjęcia dokumentujące przebieg przeprowadzonych prac konserwatorskich ujawniają nie zawsze widoczne partie rekonstruowane. Należą do nich: stopa rzeźby Chrystusa zmartwychwstałego (il. 29, 30, 32), dłonie

37 W narożnikach kompozycji zostały umieszczone personifikacje kontynentów. Ich identyfikację podpowiada Iconologia (zob. np. C. Ripa, Iconologia, przeł. I. Kania, Kraków 1998, s. 387-391). Zgodnie z jej wskazówkami postacie należałoby interpretować nastepująco: w północno-wschodnim narożniku Europa w zamkniętej koronie na głowie z głową byka oraz krzyżem, tiarą papieską i kapeluszem kardynalskim (?), a na wysokości jej ust napis VIRTUS (Cnota); w narożniku południowo-wschodnim Azja z głową dzikiego zwierzęcia oraz ukazaną w popiersiu meską postacią (?) (Ripa zalecał przedstawianie głowy pod stopami oznaczające ludożerstwo), na wysokości jej głowy napis HONOR, pomiędzy personifikacjami putta trzymają banderolę z napisem: PLENI SUNT COELI ET TERRA (pełne są Niebiosa i Ziemia); w narożniku północno-zachodnim Ameryka o ciemnej karnacji, zdobiona perłami, zgodnie z przepisem Ripy z krokodylem (ale bez strzały, kołczanu, łuku i ozdoby z piór), a nad jej głową napis GLORIA (Chwała); w narożniku południowo-zachodnim czarnoskóra personifikacja Afryki z głową słonia, jak zalecał Ripa, oraz z naczyniem (w które Ripa zaopatrzył Azję), przy jej głowie napis LAUS (Sława); pomiędzy dwiema personifikacjami od zacho$\mathrm{du}$ putto unosi banderole z napisem MAIESTAT IS GLORIAE TUAE (Majestat jest ozdobą Twoją). Krzyżanowski (Malowidła sklepienia kaplicy Kotudzkich, [w:] Katedra Gnieźnieńska, s. 341-342) postać z krokodylem identyfikował jako Afrykę, z naczyniem i głową słonia jako Azje, postać z głową zwierzęcia jako Amerykę, co wydaje się także słusznym, choć niezgodnym z zaleceniami Ripy rozwiązaniem. Jest też prawdopodobne, że tekst Iconologii został swobodnie potraktowany. Personifikacje czterech kontynentów (1777-1778) wyobrażone zgodnie z przepisami Ripy znajdują się też na sklepieniu we wschodnim przęśle nawy głównej pobernardyńskiego kościoła w Zamartem. Europa została przedstawiona w koronie i z berłem, obok niej koń i różnorodne przedmioty świadczące o znakomitej działalności jej mieszkańców, takie jak: tiara i krzyż papieski, księga, zapis nutowy czy też paleta z pędzlem; Ameryka z łukiem, z kołczanem ze strzałami i jaszczurem obok; Azja z wielbłądem i dużymi paczkami oraz z naczyniem; Afryka ze słoniem, lwem i dzidą. 
Ukrzyżowanego (il. 9), palec wskazujący apostoła po lewej stronie (il. 15) oraz palce lewej dłoni apostoła po prawej. Ponownie zamontowane zostały: lewa ręka anioła po prawej stronie oraz prawa ręka apostoła po lewej. Wykonane z gipsu są: titulus Chrystusa ukrzyżowanego (zob. il. 9, 10), części Arma Christi - końcówki wiązek rózg, bicz (il. 12, 38) oraz chusty obok części naczółka po obu stronach (il. 35). Partie rekonstruowane zostają wyłączone $\mathrm{z}$ analiz porównawczych.

\section{Sposób wykonania rzeźbiarsko-architektonicznego wyposażenia kaplicy}

Kaplica Kołudzkich - w katedrze niedostępna, bo zamknięta ozdobną krata (i1. 1), niemożliwa zwykle do obejrzenia, nawet jeśli uda się wejść do środka, bo dodatkowo jeszcze niemająca własnego dostatecznie ją oświetlającego źródła światła, bardzo ciemna, bo wyłożona czarnym marmurem (il. 4, 5) i o oknie witrażowym z blękitno-żółtymi szybami (il. 1) - ujawnia swój rzeczywisty wygląd dopiero w świetle reflektorów. Tak zapewne nigdy nie miała być oglądana, ponieważ takim światłem nie dysponowano w czasach jej projektowania. Widoczne w silnym świetle lamp wspaniałe odbicia białych alabastrowych rzeźb w lśniącej wypolerowanej powierzchni czarnego kamienia onegdaj zapewne były delikatniejsze, ale nie nieobecne (il. 2-5, 13, 18). W słabym świetle przesączającym sie przez okno i w blasku świec musiał istnieć nastrój powagi i szlachetnej elegancji, wywołanej zestawieniem czerni, brązu i bieli, dyskrecją ozdób, jednorodnością wyposażenia. Kaplica nie była powszechnie dostępna, a ci, którzy mieli prawo do niej wejść, nie byli w stanie dostrzec wszystkich jej doskonałości, ale i niedostatków wykonania. Wnętrze oddziaływało całościowo. W dzisiejszych czasach w trakcie badań wprowadza się do wnętrza oświetlenie pierwotnie niezamierzone i uwidacznia bezlitośnie to, co raczej nie miało być widoczne, „kawałkuje” to, co widziano w mroku całościowo, na poszczególne partie, a te jeszcze na detale.

Historyk sztuki studiujący kaplice współcześnie dokonuje wszelkich starań mających na celu dążenie do maksymalnie precyzyjnego poznania wszystkich jej elementów. Służą temu: dobre oświetlenie oraz fotografia analogowa i cyfrowa, często wykonywana z pozycji na wprost, z rusztowań, 
pozwalająca na wykonanie bogatego zestawu zdjęć oraz wyselekcjonowanie z nich pojedynczych detali, oglądanie ich na ekranie komputera w różnej skali, ujawniającej wszelkie tajniki warsztatu, precyzję wykonania, ślady narzędzi, stan zachowania. Dzięki temu w odniesieniu do kaplicy Kołudzkich można dostrzec i ocenić sposób wykonania rzeźb i płaskorzeźb oraz ich jakość artystyczna, klasę elementów i detali architektonicznych, a także sposób połączenia elementów składowych (np. il. 11, 15, 17, 22, 33, 37-39).

Można stwierdzić, że cechą warsztatu wykonującego montaż nie była zbyt wysoka precyzja (np. il. 38, 39). Elementy okładziny z czarnego marmuru przytwierdzano do podłoża w miarę starannie, w sposób ukrywający istnienie kotew (il. 4, 5) albo przy ich znacznym ograniczeniu dzięki użyciu kitów. Szczeliny, czasem dość szerokie, kitowano (il. 6, 34, 38). Miejsca przeznaczone pod płaskorzeźbione elementy alabastrowe podkuwano stosunkowo głęboko w celu lepszego ich osadzenia i umocowania (il. 7, 12, 34, a zwłaszcza 37 i 38). Wokól plakiet widoczne są podkucia i ich nierówna faktura, czasem efekt nakłucia powierzchni podobny do groszkowania. Zdarzały się wypadki niedokładnego spasowania poszczególnych elementów, np. pionowych profilowań (il. 38). W trudnych sytuacjach związanych z montażem odstępowano od zamierzonego kształtu i dostosowywano go w zależności od potrzeb, aby uzyskać spójność konstrukcji, przykładem jest tu podpiłowana woluta (il. 39).

Elementy architektoniczne, takie jak np. kapitele, bazy, detal płaskorzeźbiarski, reprezentują dość wysoki warsztatowy sposób wykonania. Kamień jest cięty precyzyjnie, według ustalonego wzoru, formy odznaczają się ostrymi krawędziami, są wybrane do końca, ich powierzchnia jest dość starannie opracowana, o jednolitej gładkiej fakturze.

Obserwacja powierzchni rzeźb pozwala zauważyć, że wykazują one różny sposób wykonania. Postacie apostołów oraz skrzydlate aniołki w partiach odkrytego ciała - twarzy i rak, maja powierzchnie rozedrgana, jakby niedopolerowana. Padające na nie światło tworzy refleksy rozproszone, złożone z odcinków i punktów, dające właśnie wspomniany efekt (np. il. 19). Niektóre zarysy i kontury są przez to mniej czytelne (np. il. 14). Można jednak zadać pytanie, czy nie jest to konsekwencją korozji kamienia, czy też jakichś niefachowo przeprowadzonych napraw. Rzeźba Chrystusa zmartwychwstałego wykazuje wyższy stopień gładkości (il. 29, 30). Błyski światła powstające na 
elementach najbardziej wypukłych tworzą zarysy ciagłe, jednolite, podkreślające kształty.

Można więc zapytać, czy spostrzeżenia te świadczą o udziale różnych wykonawców. W tym wypadku we wnioskach należy zachować dużą dozę ostrożności. Zauważone różnice mogą być rzeczywiście efektem odmiennej jakości pracy albo też stanu zachowania, a ściślej mówiąc, nierównomiernego stanu zniszczenia powierzchni alabastru. Na destrukcję inaczej mogą być podatne bloki wydobyte z odległych od siebie miejsc złoża albo znajdujące się w innym miejscu w konstrukcji ołtarza, o niejednakowym stopniu narażenia na działanie wilgoci.

Wydaje się jednak, że nawet wobec powyższych uwag i z uwzględnieniem ingerencji konserwatorskich można mówić o różnym sposobie opracowania powierzchni. Na rzeźbach apostołów pozostała więc raczej niedopolerowana powierzchnia z nikłymi śladami narzędzi - obróbki dłutami (?), sprawiająca wrażenie, jakby wyczuwało się jeszcze efekt pracy gradziny lub groszkownika (?). Na płycie, na której stoi postać po lewej stronie ołtarza, są widoczne ślady piły do cięcia kamienia. Zauważalne są też głębsze nacięcia materiału, silniejsze, niż wymagała tego ostateczna forma. Pozostały one niewygładzone, np. u podstawy kciuka prawej ręki figury po lewej stronie ołtarza (il. 15) oraz na kciuku lewej ręki postaci po prawej (il. 17). Nie można też mówić, że pozostałości śladów narzędzia miałyby, w zamyśle twórcy, służyć kształtowaniu efektów artystycznych.

Istotnych informacji dotyczących osób zaangażowanych w powstanie plastycznego wyposażenia kaplicy dostarczają spostrzeżenia na temat sposobu wykonania rzeźb.

W zestawie rzeźb i płaskorzeźb figuralnych są zauważalne zdecydowane różnice dotyczące nie tylko opracowania powierzchni, ale także metody i precyzji cięcia kamienia oraz zręczności dłuta, dopracowania kształtów i form, repertuaru motywów, poprawności anatomicznej, stosunku do otaczającej przestrzeni.

Postacie apostołów (il. 13-22) zostały odkute do form miękkich, obłych, dają wrażenie, jakby opracowywała je ręka nawykła do modelowania w miękkim materiale, czyli do dodawania, a nie odejmowania, tak jak to jest przy 
pracy w kamieniu, albo jakby autor chciał uzyskać efekt wykonania w miękkim materiale lub też nie posiadał zdolności lub odwagi do pracy śmielszej, kreującej formy bardziej swobodne, a fałdy szat sztywniejsze, cięte ostro. Poszczególne człony rzeźby przechodzą miękko i płynnie jedna w drugą, w efekcie brak jest precyzyjnych linii podziału, a nawet zdarzają się wyraźne połączenia poszczególnych elementów. Jest to jakby rzeźbienie z nadmiarem, jakby z obawą przed ostatecznym rozdzieleniem form. Możemy zaobserwować np., że szata zrasta się z księgą, księga z palcem, a na granicy ich zetknięcia się powstaje półkolisty łącznik - wgłębienie w zespolonych formach, a nie precyzyjne ich podcięcie i oddzielenie (il. 16, 17). Jest to rodzaj rzeźbienia „z lękiem” przed usunięciem pozostałości bloku materiału, z którego rzeźba została wykonana, wybraniem i usunięciem do końca zbędnych - z punktu widzenia estetyki i wartości artystycznych - pozostałości wyjściowej formy materiału, z lękiem o to, że forma mogłaby rozpaść się na poszczególne elementy w sensie bardziej technicznym niż artystycznym. Zauważalna jest niechęć do wejścia rzeźby w interakcje z przestrzenią, do otwarcia się na nią, wpuszczenia powietrza w obręb jej formy. Szaty sprawiają czasem wrażenie, jakby pozostały porzucone w fazie wstępnego opracowania. Fałdy układaja się miękko (il. 13, 16, 18, 20). Śmielsze formy zostały wprowadzone w przypadku figury świętego po lewej stronie (św. Piotra?, il. 18) ${ }^{38}$. Rzeźby apostołów wyraźnie potrzebują oparcia w znajdujących się za nimi płytkich niszach, stoją wobec nich niemal równolegle, frontalnie do widza, lekko tylko zwrócone w stronę Chrystusa ukrzyżowanego umieszczonego w polu środkowym (il. 2, 13, 18), zostały zakomponowane antytetycznie wzgledem osi ołtarza, dostosowując się do pionu architektury ołtarza od wewnątrz, rozwijają się po łuku od strony zewnętrznej (il. 13, 18).

38 Można zastanawiać się, czy np. wyłożone fałdy, jakby wywinięcia tkaniny, układające się w partii rękawa (il. 13, 18, 25, 27) w formy o kanciastych kształtach, są cechą pracy wykonawcy, efektem niedorzeźbienia, czy też próby naśladowania stylu osoby tworzącej z tego typu fałd śmiałe, sztywne konstrukcje, jak np. w przypadku postaci aniołków na portalu wiodącym do kaplicy Kołudzkich (il. 1, 41), gdzie kamień jest cięty zdecydowanie i odważnie, tworząc układy wprawdzie dalekie od natury, ale ciekawe (różnice dwu sposobów modelowania zob. il. 40, 41). 
Na skutek opisanego powyżej sposobu działania powstałe formy cechuje słabe opracowanie anatomiczne powierzchni, choć zdarzają się próby indywidualizacji, np. zmarszczenie czoła i ściagnnięcie brwi apostoła, oraz nadania postaciom znamion późnego wieku (il. 14, 19). Twarz apostoła po prawej stronie sprawia wrażenie malarsko potraktowanego szkicu, a ta szkicowość działa tu na rzecz ekspresji formy (il. 19). Układ pukli włosów stanowi rytmiczne powtarzanie podobnych kształtów o łagodnych łukach i miękkim cięciu (il. 15, 19). Dłonie tworzą formy o mało zróżnicowanej powierzchni, palce są długie, jednostajnie wąskie, wręcz rurkowate, raczej pozbawione modelowania, o ledwo zaznaczonych kostkach (il. 15-17, 20, 21). Palce i inne formy „są sklejone” resztką kamienia, będącą częścią bloku, z którego rzeźba powstała (il. 17), a której nie usunięto z przyczyn technicznych, zręcznościowych (braku umiejętności), transportowych i bezpieczeństwa, niedopatrzenia lub pośpiechu (?) albo zgodnie z przyjętą w warsztacie zasada, wynikającą z któregoś z wymienionych względów. Ugięte palce, serdeczny i środkowy prawej ręki figury po lewej stronie ołtarza, zostały wydobyte z kamienia jedynie od strony zewnętrznej, wewnątrz nadal pozostają złączone z materiałem, z którego została opracowana cała dłoń (il. 15).

Przykładem nieorganicznego, jakby addycyjnego kształtowania całej postaci jest lewa ręka figury apostoła po lewej, która wyrasta z całej rzeźby, jakby była „doklejona” (nie tylko do ciała, ale i do bloku, z którego jest ukształtowana cała postać, wyczuwa się, że wychodzi poza jego zarys) i usytuowana zbyt blisko korpusu, choć znajduje kontynuację w części skrytej szatami (il. 13). Stopy figur apostołów, ukazane w skrócie, zatracają swój kształt, zrastają się z kamiennymi blokami znajdującymi się obok nich - jest to raczej efekt uproszczenia lub nieudolności niż tylko symbolicznego potraktowania formy wyrażającej myśl o tym, że św. św. Piotr i Paweł (il. 22) stanowią podstawę Kościoła (?). Takie postępowanie - celowe albo nieudolne - budzi zdziwienie, gdyż rzeźby stóp w tym specyficznym układzie znajdują się dość nisko i są raczej dobrze widoczne. Można stwierdzić, że stopa, kamień, fałdy, postument i pozostałości bloku materiału rzeźbiarskiego stanowia jedną całość. Rzeźby próbowano ożywić poprzez kontrapost (il. 13, 18), układ dłoni oraz mimikę twarzy (il. 14, 19). Przekazywanie budowy ciała przez szaty jest uwidocznione w partii nóg obu postaci apostołów (il. 13, 18, 20). 
Podobnie miękkie opracowanie, ze skłonnością do niedocinania kamienia, jest zauważalne $\mathrm{w}$ przypadku postaci Chrystusa ukrzyżowanego (il. 9-11). Nierozdzielone zostały nogi rzeźby w górnej partii ud (il. 11), na niemal całej długości podudzi i stóp (il. 9). W partii stóp rzeźba jest zrośnięta w jeden blok, w którym kształt tej umieszczonej na wierzchu ulega zatraceniu (il. 9). Formy podudzi są niedorzeźbione i niedocięte, niewydobyte do końca z bloku materiału. Jedna zatapia się w drugą jak w miękką materię. Wówczas ta spodnia traci swój kształt na rzecz tej wierzchniej, jakby była miękka, jakby ciało mogło ugiąć się w tak dużym stopniu. Układające się obok ciała perizonium (il. 9, 11) tworzy wprawdzie formy sztywne, ale zbudowane z miękko układających się i miękko opracowanych fałd. Niezbyt precyzyjnie cięty kamień, o nieostrych krawędziach, półkoliście i dość wypukło wyrzeźbiony na linii styku z ciałem Chrystusa (il. 11), tworzy wrażenie tkaniny mięsistej i grubej. Proporcje postaci są raczej krępe, odchylona do tyłu głowa dość duża, twarz o ekspresyjnym, dramatycznym wyrazie, o oczach uniesionych do góry i otwartych, o opuszczonych kącikach ustach ukazujących zęby (il. 10). Całe ciało rzeźbiarsko zostało potraktowane dość sumarycznie. Klatka piersiowa w widoku bocznym bardziej rozrzeźbiona, o dość plastycznie modelowanych łukach żeber, gdzie kamień wybierany głębiej tworzy efekty światłocieniowe (il. 10). Rekonstruowany z gipsu titulus wyraźnie cechuje inny sposób cięcia materiału przypominający opracowanie rzeźbiarskie drewna (il. 9).

Aniołki ze zwieńczenia (il. 25-27, 40) zakomponowane w antytetycznym układzie względem osi ołtarza, tworzące swą bryłą zarys trójkątny, zostały usytuowane na półkolach naczółka z nogą znajdującą się na zewnątrz, uniesioną, jakby zastygłą w ruchu, a drugą opuszczoną, o rękach ugiętych i uniesionych do góry, z dłońmi o zgiętych palcach, tak jakby miały w nich coś trzymać (banderola z inskrypcją?, il. 3, 25, 27). Zdają się powtarzać raz wypracowany w warsztacie model w wersji zależnej od umiejętności aktualnie pracującego rzeźbiarza. Cechuje je miękkie cięcie oraz wyraźne niedopracowanie formy, wykazują najniższy poziom artystyczny w całym zestawie rzeźb i płaskorzeźb wyposażenia kaplicy Kołudzkich. Umieszczone są też najwyżej, były więc najsłabiej widoczne i dlatego w pewnej mierze zostały pozostawione w fazie szkicowej. Wydobyto zasadnicze kształty określające postać i jej pozę, gdzieniegdzie figura została lepiej opracowana rzeźbiarsko, jak np. w partii fałd rękawa szaty po lewej stronie w przypadku aniołka umieszczonego na 
fragmencie naczółka po lewej stronie ołtarza (il. 25). Fałdy te, choć w najniższej partii czę́ciowo także są w fazie wstępnego cięcia doprowadzającego do form prostych i płaskich, powyżej są staranniej ukształtowane. Podobna próba została podjęta w przypadku lewej ręki aniołka po przeciwnej stronie ołtarza (il. 27-40). Twarze pozostawione we wstępnej fazie opracowania rzeźbiarskiego, słabo rzeźbione, potraktowane zaledwie szkicowo, z cieniem nikłego uśmiechu (il. 25, 27). Dominują w nich kształty wypukłe, stwarzające efekt „zapuchnięcia” (obserwowany też w innych partiach ciała). Powtarzają się małe, zakończone kuleczką perkate noski, pucołowate policzki, uwypuklone bródki (il. 33, 36). Na nadgarstkach i szyi zostały płytko zaznaczone fałdki skóry. Włosy utworzone z mięsistych, słabo rozrzeźbionych, miękko opracowanych loków (podobnie jak w przypadku uskrzydlonych główek aniołków), z charakterystycznym dla lat 30 . XVII wieku wypiętrzonym czubkiem. Fałdy szat skąpe w partii tułowia, obfitsze w partii rękawów, niewybierane precyzyjnie w zagłębieniach, gdzieniegdzie są widoczne nieusunięte pozostałości materiału (il. 26). Niektóre formy nie zostały wykształtowane w pełni. Przykładem jest prawa stopa postaci po lewej stronie (il. 26), gdzie zostały uformowane jedynie palce, dalszy jej kształt „wtapia się” w zaledwie w cylindrycznej formie pozostawioną partię nogi (ta część rzeźby nie mogła być widziana od dołu).

W przypadku rzeźby Chrystusa zmartwychwstałego (il. 28-33) kwestia jakości pracy rzeźbiarza przedstawia się całkowicie odmiennie. Figure tę cechuje dość dobre opracowanie anatomiczne, lepszy poler, brak śladów narzędzia, staranniejsze wybieranie pozostałości kamiennego bloku, ciekawa, swobodna kompozycja, zapewne oparta na wzorze malarskim lub graficznym ${ }^{39}$. Rzeźba ma zmienny i rozbudowany kontur, zróżnicowane stopnie

39 Zostal tu przedstawiony temat popularny w sztuce gdańskiej. Zob. np. rep. K. Cieślak, Epitafia obrazowe w Gdańsku (XV-XVII w.), Wrocław-Warszawa-Kraków 1993, il. 9b Zmartwychwstanie Chrystusa, miedzioryt Filipa Galle'a lub braci Duetecum wg Fransa Florisa, 1557 (wzór dla odwróconego tyłem żołnierza po lewej stronie oraz układ nóg tego po prawej); il. 12d - Zmartwychwstanie Chrystusa, anonimowy obraz z Muzeum Narodowego w Gdańsku, ok. 1560-1570 (Chrystus zmartwychwstający w obłokach ponad perspektywicznie przedstawionym sarkofagiem, uzbrojenie żołnierzy, muskulatura); il. 14b - Zmartwychwstanie Chrystusa, miedzioryt Cornelisa Corta wg Michiela Coxie, przed 1565 (poza Chrystusa wznoszącego się wśród obłoków ponad sarkofagiem przedstawionym perspektywicznie, otulonego 
wypukłości szaty i ciała. Formy są opracowane dość miękko, jakby malarsko. Sprawiaja wrażenie płynnych (il. 29, 30). Wspomniany efekt płynności dotyczy mniejszych elementów oraz linii całego ciała, w którego kompozycji jest wyraźnie wyczuwalny zarys litery „s”. Wyznaczają ją elementy twarzy, zagłębienia klatki piersiowej oraz kontur prawej nogi. Brak jest precyzyjnie wyprowadzonych krawędzi zarówno szat, jak i części ciała. Twarz, dość znacznie rozrzeźbiona, sprawia wrażenie „wykonanej jakby z miękkiego nadtopionego wosku" (il. 29, 30). Cała twarz i włosy są zbudowane z wzajemnie przenikających się miękko wklęsłości i wypukłości, co wprowadza efekt gry świateł i cienia. Partie ciała różnią się jakością wykonania. Znacznie lepsze wydają się partie klatki piersiowej. Słabsze pod względem opracowania anatomicznego wydają się natomiast ręce postaci, a szczególnie dłoń trzymająca chorągiew (il. 29, 30). Szaty rozwiane wokól ciała, w znacznej mierze stanowiące dlań tło, modelowane są z dość dużych połaci gładko wybieranego materiału rozdzielonego wąskimi, niezbyt wysokimi fałdami. Bardziej rozbudowane układy fałd zostały wykonane wokół nóg oraz lewej ręki. Artyście udało się osiągnąć efekt wznoszenia się postaci.

Cała grupa sceny Zmartwychwstania także wykazuje brak jednorodności w sposobie kształtowania formy rzeźbiarskiej (il. 28-33). Szczególnymi cechami odznaczają się płaskorzeźbione postacie żołnierzy skupionych wokół grobu Chrystusa. Dominuje w nich upodobanie do skrótów perspektywicznych ciała, wynikające z samej kompozycji, ale też stanowczo ze skłonności wykonawcy pracy do ich stosowania. Efektem tego są raz skróty udane, choć może nieco zbyt silne, jak w przypadku twarzy żołnierza po prawej (il. 33), i całkiem chybione w formie, jak w przypadku nogi żołnierza po lewej (il. 31). Ciała postaci reprezentują typy mocne, silne, krępe i umięśnione. Zostały one wykonane z wyraźnym nastawieniem na poszukiwanie i oddanie w rzeźbie wszystkich zmiennych kształtów. Uwypuklona została muskulatura. Ręce i włosy są przedstawione precyzyjnie. Tkaniny szat tworzą układy sztywne

rozwianym płaszczem z krzyżem, z choragwią, z uniesioną ręką w geście błogosławieństwa, leżący na pierwszym planie żołnierz, o układzie odwróconym względem grafiki), oraz 28b Zmartwychwstanie Chrystusa, miedzioryt Mateusza Meriana, 1627 (głównie postać Chrystusa wznoszącego się ponad perspektywicznie przedstawionym sarkofagiem, układ odwrócony, ale pozycja ciała oraz gest błogosławiącej ręki, a także rozwiane tkaniny są podobne). 
i sprawiają wrażenie, że są z grubego, mięsistego materiału. Płaskorzeźba jest silnie związana z podłożem, niemal w całej scenie. Do wyjątków należą prawa ręka odwróconego tyłem żołnierza po lewej stronie oraz częściowo jego szata (il. 31), a także lewa ręka żołnierza po przeciwnej stronie (il. 32). Partie głęboko drążone i podcięte pod ukształtowaną zewnętrzną powierzchnią są ocienione od spodu, ponieważ zostały odcięte od podłoża, we fragmentach ukształtowane trójwymiarowo i dzięki temu nie tylko ciekawsze i bardziej mistrzowskie jako forma rzeźbiarska, ale także lepiej czytelne, co nie jest bez znaczenia wobec umieszczenia grupy Zmartwychwstania w najwyższych partiach ołtarza (il. 3). W scenie tej przestrzeń i zależności kompozycyjne poszczególnych elementów określono poprzez wzajemne przekrywanie się oraz stopnie wypukłości. Płaskorzeźba zdradza zapożyczenia, najprawdopodobniej z wzorów graficznych rodem ze sztuki niderlandzkiej i niemieckiej ${ }^{40}$.

\section{Elementy dekoracyjne}

Fałdy podwieszonej w trzech punktach tkaniny - chusty św. Weroniki (il. 2, 6) - układają się miękko i miękko są też opracowane. Po bokach tworzą łagodne, regularne kaskady, u góry miękkie, dość wypukłe formy o przebiegu zakłóconym nieregularnymi, silniejszymi zagłębieniami. Podwieszone fałdy oraz opadające po bokach spływy dość zdecydowanie są odcięte od podłoża, a nawet lekko podcięte, tworząc wyraźny zarys oraz - stosownie do oświetlenia - pasmo cienia. Z uwagi na brak ostrych, precyzyjnie dopracowanych krawędzi tkanina sprawia wrażenie ciężkiej i grubej. Poler całej chusty św. Weroniki jest raczej staranny (zob. jednorodny błysk światła w wybrzuszeniu nosa, il. 6).

Płaskorzeźba głowy Chrystusa jest opracowana dość wypukło. W górnej partii zdecydowanie wydobyta z tła, w dolnej zaś, o mniejszej wypukłości, okolonej lokami włosów, weń zatopiona. Twarz, potraktowana sumarycznie, rzeźbiona miękko, dość szkicowo, wykazuje cechy lekkiej asymetrii (il. 6). Oczy są słabo opracowane rzeźbiarsko. Lewe jest większe, bardziej wypukłe, zaledwie wydobyte z materiału rzeźbiarskiego, o lekko zarysowanej powiece,

40 Por. przypis 39 niniejszej pracy. 
w przeciwieństwie do oka prawego - mniejszego, głębiej osadzonego, o silniej zaznaczonej powiece i nieznacznym wgłębieniu w miejscu źrenicy. Podobnie szkicowo rzeźbiona jest korona cierniowa i włosy, których faliste loki układają się w dość schematyczne, rytmicznie powtarzane układy. W partii brody pojawiły się elementy graficzne. Znacznie uwypuklona partia wąsów optycznie dzieli twarz na dwie części.

Uskrzydlone główki puttów (il. 3, 7, 37) zostały opracowane niemal w pełni trójwymiarowo. Cechuje je miękkie, szkicowe, lub wręcz malarskie potraktowanie formy. Twarz odznacza się słabą asymetrią, widoczną w opracowaniu nosa, a szczególnie oczu (w przypadku putta po lewej spowodowaną zapewne wadami materiału; w przypadku tego po prawej jest to efekt innego opracowania lewego oka - brak wypracowania zarysu górnej, lekko opuszczonej, jak po przeciwnej stronie twarzy, powieki - lub także ingerencji konserwatorskich). Pukle krótkich, bujnych, kręconych włosów tworzą układ izolowanych wzgórków, schematycznych, gładkich, jedynie gdzieniegdzie wgłębionych, zakręconych na końcach, co zostało uzyskane przez wydrążenie w nich okragłego wgłębienia (il. 7). Wielowarstwowe skrzydła są płaskie i ledwo opracowane, miejscami pozostawione we wstępnej fazie obróbki. Ich forma jest efektem narzucenia (cena za prace, pośpiech) lub przyjęcia (cecha warsztatu) niskiego poziomu wykonania rzeźby, nieukończenia pracy lub chęci tworzenia wrażenia szkicowości, lub też świadomości w pewnym stopniu ograniczonej możliwości oglądu w ciemnej kaplicy.

Girlanda owocowo-listna tworzy formę ciężką, masywną, rzeźbioną jakby na powierzchni (il. 34).

\section{Elementy konstrukcji architektonicznej oraz detal}

Wykonane z czarnego marmuru elementy konstrukcyjne, a także detal architektoniczny ołtarza oraz okładzina i pilastry ścian kaplicy są cięte precyzyjnie i zostały dobrze wypolerowane (il. 2-5, 8, 12, 24, 35). Profile są starannie wyprowadzone, o stosunkowo ostrych krawędziach (il. 2, 3, 8, 35). Jednakże ich montaż, jak już zostało to stwierdzone, jest niedokładny (il. 8, 38, 39). Wykonane z czarnego marmuru i białego alabastru elementy dekoracyjnych wolut i mięsistych ceowników są lekko wypukłe, tak jak drobniejsze profilowania (np. w zwieńczeniu obok herbu oraz pola z uszakami, il. 3), gdzieniegdzie są 
potraktowane dwuwarstwowo (il. 23). Wykonane z białego alabastru kapitele (il. 43) dowodzą biegłości warsztatowej w zakresie detalu architektonicznego. Są one starannie opracowane. Ich formę rzeźbiarską cechuje dość precyzyjne cięcie, konsekwentne wyprowadzenie, kontynuowanie i wykończenie przestrzennych kształtów, a w efekcie dokładniejsze krawędzie, ażurowość i wielowarstwowość konstruujących je elementów dekoracyjnych.

\section{Wnioski}

Dokonując podsumowania powyższych spostrzeżeń, można stwierdzić, że w pracach nad architektoniczno-rzeźbiarskim wyposażeniem kaplicy Kołudzkich brały udział różne osoby, odznaczające się niejednakową biegłością techniczną i nierównym poziomem artystycznym. Ogólnie można skonstatować, że w zaangażowanym warsztacie znacznie lepiej były wykonywane elementy konstrukcji architektonicznej oraz detalu, zapewne według ustalonych, przyjętych i powtarzanych wzorców, choć ich wymierzenie musiało być niestaranne, czego omawiane dzieło dowodzi (np. il. 38, 39). Znacznie słabsze było opracowanie rzeźby figuralnej, co także mogło zależeć od poziomu umiejętności zaangażowanych w jej wykonanie osób. Tu również w miarę możliwości zapewne wykorzystywano i powtarzano ustalone wzory, które jednak zależnie od pracującego aktualnie rzeźbiarza nabierały określonego charakteru i jakości. Na podkreślenie zasługuje fakt, że w tej samej realizacji spotykamy partie o znacznie wyższym poziomie artystycznym i technicznym. W ramach możliwości interesującego nas warsztatu było więc wykonanie płaskorzeźby grupy Zmartwychwstania, znacznie staranniej ukształtowanej i wykończonej pod względem rzeźbiarskim, a sposób opracowania powierzchni i np. cięcie fałd szat wskazywałyby na autorstwo tej samej grupy rzeźbiarzy.

$\mathrm{Na}$ podstawie analizy cech formalnych rzeźb i płaskorzeźb można zaproponować wyróżnienie udziału trzech wykonawców (?) w kształtowaniu rzeźbiarskiego wyposażenia wnętrza kaplicy. Jeden z nich reprezentuje formy miękkie, sztampowe, związane z blokiem użytego kamienia (gł. figury apostołów, il. 13-22, a także siedzące anioły, il. 25-27). Drugi odznacza się wyższym artyzmem, śmiałością cięcia i poprawnością anatomiczną (rzeźba 
Chrystusa zmartwychwstałego, il. 28-30). Trzeci stosował z upodobaniem skróty perspektywiczne i chętnie rzeźbił detale przedmiotów i umięśnienie ciała (grupa żołnierzy ze sceny Zmartwychwstania, il. 31-33; niewątpliwie oddziałał tu też wpływ wzorów graficznych). Rzeźba portalowa prezentuje inne cechy. Zdradza ona prace rzeźbiarza nawykłego do kształtowania form sztywnych, śmiałych, precyzyjnie określonych (il. 41).

Można wobec tego zapytać, czy w przypadku rzeźbiarsko-architektonicznego wyposażenia kaplicy Kołudzkich mamy do czynienia z wieloetapową realizacją, angażującą różnych mistrzów lub warsztaty. Odpowiedź jest następująca: mamy do czynienia raczej z jednym warsztatem i działalnością w jego ramach różnie uzdolnionych czeladników. O tym warsztacie można też powiedzieć, że albo nie stosowano w nim należytego odbioru prac, albo był on nadmiernie obciążony zamówieniami i czasem termin wykonania był ważniejszy od jakości ukończenia zadania. W sytuacji pośpiechu (?), albo z zasady ${ }^{41}$, zręcznie pozostawiano w formie szkicowej to, co miało być umieszczone wysoko i w słabym świetle niewidoczne. Na poziom artystyczny dzieła, obok możliwości warsztatu, czasu przeznaczonego na realizację i warunków ekspozycji wykonanej pracy, wpływ mogły mieć także kwestie płatności oraz zapewne rangi zamówienia.

Powyższe uwagi są próbą rozpoznania możliwości i sposobu realizacji zlecenia przez wieloosobowy warsztat skupiający różne indywidualności. Punktem wyjścia naszych dalszych rozważań formalnych jest więc respektowanie i uwzględnianie $\mathrm{w}$ nich systemu pracy warsztatowej o kolektywnym charakterze, w którym wykorzystuje się wzorniki i doświadczenia innych, realizuje projekty własne, ale i zlecone, zmienia się skład zespołu w zależności od potrzeb ${ }^{42}$.

Nawiązując do ustaleń dotyczących atrybucji wyposażenia kaplicy Kołudzkich, należy zapytać, czyj warsztat rozpoznajemy poprzez analizę jej form rzeźbiarskich - Sebastiana Sali czy Wilhelma Richtera.

41 Na taką cechę pracy warsztatów gdańskich wskazał Lech Krzyżanowski (Katedra Gnieźnieńska, s. 291).

42 Zob. K. Kalinowski, Warsztat barokowego rzeźbiarza, „Artium Quaestiones” VII, Poznań 1995. 
O życiu i działalności Sebastiana Sali zebrano już nieco informacji, ale wciąż według opublikowanego stanu badań do jego dzieł potwierdzonych źródłowo należą nagrobki Piotra Opalińnkiego w Sierakowie oraz Oppersdorfów w Głogówku. Potwierdzonymi dziełami Wilhelma Richtera są cztery portale gnieźnieńskiej katedry oraz epitafium Guldensternów w kościele Mariackim w Gdańsku ${ }^{43}$.

Dalszym krokiem badawczym, niemieszczącym się już w ramach tej wypowiedzi, byłoby więc szczegółowe porównanie wspomnianych „pewnych” dzieł obu autorów z elementami wyposażenia kaplicy Kołudzkich, a następnie innych wyselekcjonowanych dzieł: np. portalu pomnika grobowego Anny Wazówny, ołtarza Opłakiwania z kościoła św. Michała w Gdańsku, zespołu ołtarzy w kościele pocysterskim w Oliwie.

Po omówieniu wyników analizy formy dzieł rzeźbiarskich kaplicy przypomnijmy niektóre tylko elementy stanu badań.

Jak to zostało powiedziane na wstepie, autorstwo kaplicy i portalu przypisywano najpierw Sebastianowi Sali, a potem Wilhelmowi Richterowi. Atrybucje te są zadziwiające i - wydawałoby się - jednocześnie nieprawdopodobne - ze względu na reprezentowanie przez autorów zgoła różnych orientacji artystycznych, jak i prawdopodobne - ze względu na znane przecież przejmowanie wzorów oraz wymieszanie form o proweniencji północnej i południowej. (W przypadku twórczości Sebastiana Sali na taką jej cechę wskazywała Karolina Targosz). Zadziałał tu także zapewne dość chyba często stosowany przed laty w naszej historii sztuki mechanizm „obdzielania” dziełami poznanych nazwisk rzeźbiarzy, niepokojący niejednokrotnie swą zbytnią śmiałością i brakiem zawahania choćby na tyle, aby dodać, że dzieło jest jedynie „w stylu określonego artysty”, a nie na pewno jego autorstwa. To zaś prawdopodobnie wynika, po pierwsze - z kłopotów ze źródłowym rozpoznaniem środowiska rzeźbiarskiego w Polsce w XVII wieku, ze względu na stopień zniszczenia polskich archiwaliów, a po drugie - z popularnych metod badawczych w latach 50. i 60. XX wieku, kiedy kładziono silny nacisk

43 Informację tę podał dr Jacek Kriegseisen na sesji naukowej poświęconej „Rzeźbie w Prusach Królewskich”, która odbyła się w Gdańsku w dniach 18-19 września 2009 r., w referacie pt. „Epitafium Guldensternów w kościele Mariackim w Gdańsku i jego twórca Wilhelm Richter. Addenda et corrigenda". 
na badania stylu i atrybucyjne, których ambicją było zakończenie ich zwykle podaniem konkretnego nazwiska.

Sebastianowi Sali lub warsztatom dębnickim przypisała autorstwo kaplicy Kołudzkich Aniela Sławska. Walkowski i Polkowski sądzili, że twórcy wyposażenia zabytku należy szukać wśród rzeźbiarzy gdańskich. Karolina Targosz wskazała na „fabrykę” dębnicką ze względu na niższy poziom kaplicy Kołudzkich w porównaniu z dziełami Sali, z czym należy się zgodzić w świetle powyższych spostrzeżeń.

Prowadzone ostatnio przez Michała Wardzyńskiego badania nad rodzajem kamiennych materiałów rzeźbiarskich doprowadziły do włączenia architektoniczno-rzeźbiarskiego wyposażenia kaplicy Kołudzkich wykonanego z czarnego marmuru do zespołu zabytków powstałych z marmurów południowoniderlandzkich ${ }^{44}$ i tym samym kwestie udziału dębnickiej „fabryki” stały się nieaktualne.

Zdaniem Lecha Krzyżanowskiego, opinie Walkowskiego i Polkowskiego o powstaniu wyposażenia kaplicy w warsztatach gdańskich potwierdza „W całej rozciąłłości” analiza stylistyczna. Badacz ten przypisał zarówno portal, jak i pozostałą część plastyki kaplicy Kołudzkich warsztatowi Wilhelma Richtera. To stwierdzenie dotyczace udziału jednego warsztatu w pracach związanych z kaplicą musi zostać poddane rewizji. Aby się do niego odnieść, trzeba szczegółowo porównać formy rzeźbiarskie portalu i wyposażenia kaplicy. Samo zaś przypisanie wykonawstwa warsztatowi Richtera może nastapić także dopiero po przeprowadzeniu gruntownej analizy formy oraz analizy stylistyczno-porównawczej, a odniesieniem powinny być tu cztery portale gnieźnieńskie o potwierdzonej źródłowo atrybucji Richterowi oraz dodane ostatnio do dzieł „pewnych” tego rzeźbiarza gdańskie epitafium Guldensternów ${ }^{45}$. To zadanie zaś wymaga też sporządzenia szczegółowej dokumentacji fotograficznej i wnikliwej pracy na jej podstawie. Jednakże już we wstępnej fazie badań możemy stwierdzić, że rzeźby z portalu wiodącego do kaplicy Kołudzkich w porównaniu z tymi znajdującymi się w jej wnętrzu cechuje lepsza jakość artystyczna i techniczna, staranniejsze opracowanie

44 M. Wardzyński, op. cit.

45 Zob. przypis 43. 
partii anatomicznych postaci naczółków. Szaty są cięte dokładniej, krawędzie ostrzejsze (il. 41), rzeźby zostały „uwolnione” z pozostałości wyjściowego bloku kamienia, wykazują swobodne potraktowanie wzorów natury, w twarzach jest zauważalny większy dynamizm.

Krzyżanowski sądził, że jakość plastyki figuralnej w całej kaplicy Kołudzkich jest lepsza aniżeli w pozostałych portalach tego warsztatu, z czym w świetle analizy formalnej - trudno się zgodzić. Opinię swą tłumaczył tym, że w odziedziczonym po Abrahamie van den Blocku największym w Gdańsku warsztacie Wilhelm Richter był raczej kierownikiem tego przedsiębiorstwa, podobnie jak wcześniej Abraham. Dlatego też - pisał - poziom plastyki figuralnej zależał od umiejętności czeladnika wykonującego powierzoną pracee $^{46}$. Tę opinię analiza formy potwierdza.

Kończąc rozważania dotyczące warsztatu działającego przy realizacji wyposażenia architektoniczno-rzeźbiarskiego kaplicy Kołudzkich, warto zauważyć, że podobne w charakterze były atrybucje wysuwane w literaturze przedmiotu w stosunku do nagrobka arcybiskupa Wawrzyńca Gembickiego ${ }^{47}$ oraz portali prowadzących do kaplic katedry gnieźnieńskiej ${ }^{48}$. W tej kwestii

46 LK [L. Krzyżanowski], Portal kaplicy Kotudzkich, s. 310-311.

47 Stanisław Wiliński w 1956 r. przypisał nagrobek arcybiskupa Gembickiego znajdujący się w kaplicy Niepokalanego Poczęcia NM Panny w katedrze w Gnieźnie warsztatowi Sebastiana Sali, opierając się na analogiach z nagrobkiem Piotra Opalińskiego w Sierakowie, którego wykonanie przez Sebastiana Salę zostało potwierdzone źródłowo. Wcześniej jednak nagrobek Gembickiego przypisywano Richterowi. Zob. S. Wiliński, op. cit., s. 77; J. Eckhardt, Geneza nagrobków barokowych $w$ stylu Florisa na Pomorzu $i$ Wielkopolsce, „Biuletyn Historii Sztuki i Kultury", R. 2: 1933, nr 1, s. 67; U. Thieme, F. Becker, Allgemeines Lexicon der Bildenden Künstler, t. 28, 1954, s. 302.

48 Podobnie zarysował się stan badań dotyczący portali prowadzących do okalającego korpus katedry i ambit wieńca kaplic. Do czasu publikacji zbiorowego opracowania poświęconego katedrze gnieźnieńskiej w roku 1970 (Katedra Gnieźnieńska) sprawa autorstwa portali nie była przesądzona. W roku 1965 w monografii Gniezna Aniela Sławska (Barok, s. 410-411) wysunęła przypuszczenie, że łączą się one z warsztatami dębnickimi. Podobne przekonanie wyraził także Władysław Tatarkiewicz (W. Tatarkiewicz, Czarny marmur w Krakowie, [w:] O sztuce polskiej XVII i XVIII wieku, Warszawa 1966, s. 391), który stwierdził, że gnieźnieńskie czarne marmury wiążą się z działalnością kamieniołomów dębnickich. Dopiero badania archiwalne przeprowadzone w związku z przygotowaniem monografii wydanej w 1970 r. ostatecznie jak stwierdził Lech Krzyżanowski - przesądziły sprawę atrybucji portali. Odnaleziony został kontrakt z Wilhelmem Richterem pochodzący z roku 1653 (Katedra Gnieźnieńska, s. 304, 
także padały nazwiska Richtera i Sali. Problem zależności Sala-Richter czeka na rozwiązanie ${ }^{49}$.

Wszelkie dyskusje dotyczące warsztatu pracującego w kaplicy Kołudzkich istotne są też dla problemu autorstwa pomnika grobowego Anny Wazówny. Zauważalne podobieństwa we wspomnianych zabytkach zachęcają do rozważenia kwestii udziału $\mathrm{w}$ ich powstaniu tego samego warsztatu oraz próby określenia prawdopodobnego stopnia jego zaangażowania w realizacji toruńskiej. Zarówno zabytek gnieźnieński, jak i toruński należą do tych dzieł, w których czarny marmur wystepował nie tylko jako aplikacja, ale stał się także podstawą stworzenia jednolitego, kompleksowego wyposażenia.

Przykładami całościowych wnętrz wykonanych z czarnego marmuru są krakowskie mauzolea Zbaraskich przy kościele Dominikanów (1629-1633), Wazów (1664-1676) w katedrze na Wawelu oraz w znacznym stopniu kaplica Mariacka w katedrze na Wawelu (przebudowa 1647-1650). Pomnik grobowy Wazówny oraz kaplica Kołudzkich stanowią reprezentację tego typu tendencji na terenie północnej części kraju.

W obu realizacjach czarny marmur jest podstawowym budulcem głównego elementu kreowanego wnętrza - w Gnieźnie kaplicy, w Toruniu portalowej niszy grobowca, jakimi są odpowiednio ołtarz oraz nagrobek przyścienny. W obu zastosowano modny wówczas kontrast marmuru czarnego oraz białego alabastru, z którego została wykonana plastyka figuralna, elementy zdobnicze oraz detal architektoniczny, w obu wprowadzono też wykładzinę

na s. 433 Umowa z Wilhelmem Richterem, kamieniarzem), na podstawie którego przyjęto, że w roku 1654 na zamówienie kapituły gnieźnieńskiej powstały w gdańskim warsztacie Richtera cztery portale w katedrze: dwa dwustronne w arkadach prezbiterium, portal kaplicy Pana Jezusa oraz kaplicy Bożego Ciała.

49 Propozycje atrybucyjne były związane z ówczesnym ogólnym stanem wiedzy na temat rzeźby XVII-wiecznej w Polsce. Hipotezy opierano często na zbyt nikłych przesłankach, a także niedostatecznych badaniach. Wpływ na to miały także cechy samych zabytków prezentujące jednocześnie motywy i formy stosowane w różnych środowiskach. Niewątpliwie znane, potwierdzone źródłowo fakty zaangażowania w prace rzeźbiarskie w katedrze gnieźnieńskiej obu artystów - Sali (nieukończone mauzoleum nad grobem św. Wojciecha, model i projekt 1644; zob. Katedra Gnieźnieńska, s. 432-433) i Richtera (4 portale, zob. przyp. powyższy) miały także wpływ na atrybucje wysuwane w stosunku do innych dzieł znajdujących się w tej samej świątyni. 
ścian płytami z czarnego marmuru oraz posadzkę z ułożonych w ukośną szachownice płyt czarnych i białych.

Podobieństwa obu realizacji nie dotyczą jednak tylko ogólnej dyspozycji wykorzystania materiałów oraz w rezultacie efektu elegancji, barwnego kontrastu i nastroju powagi. Należy do nich zaliczyć przede wszystkim zastosowanie podobnych elementów architektonicznych, detalu i motywów dekoracyjnych portalu pomnika grobowego Wazówny oraz głównie ołtarza kaplicy Kołudzkich, a w dalszej kolejności trzeba zwrócić uwagę na sposób wykonania kamieniarki.

Wspomniane powyżej elementy architektoniczne (il. 2, 3, 35, 43) interesujących nas zabytków to zastosowanie motywu łuku triumfalnego w przypadku zabytku toruńskiego, przetworzonego w zabytku gnieźnieńskim, zbudowanego z kolumn stojących na cokołach, o bazach ustawionych bezpośrednio na prostych płytach, o korynckich kapitelach, dźwigających wysunięte w osi kolumn do przodu odcinki belkowania oraz cofnięty gzyms, półkola rozsuniętego naczółka z plastyką figuralną oraz umieszczoną między nimi nastawę ze zwieńczeniem. Belkowanie w obu zabytkach składa się z wąskiego dwuczęściowego architrawu, gładkiego, w miare wysokiego pasa fryzu oraz znacznie szerszego od poprzednich elementów słabo rozprofilowanego gzymsu (bogaciej w przypadku pomnika Wazówny), zbudowanego głównie z dość szerokiej belki o wąskiej listwie wymodelowanej od spodu (il. 2, 3, 35). Na podkreślenie zasługuje fakt, że zastosowane bazy (il. 2, 8) w obu przypadkach mają identyczną budowe, a kapitele tę samą konstrukcję i podobne elementy zdobnicze, choć indywidualnie przetworzone ${ }^{50}$. Można jednakże

50 Kapitele są zbudowane z kosza ukształtowanego z dwu poziomów wywiniętych na końcach liści akantu, wspierających sie na nich czterech zawiniętych narożnych wolut, wyprowadzonych wąskim pasem z dwu stron, złączonych pośrodku wąską poprzeczką, oraz dwu mniejszych wolutek usytuowanych pomiędzy nimi, wspartych na jednym dłuższym liściu stylizowanego akantu oraz na zawiniętych wiciach dekoracyjnej formy, wspartej na wydłużonym słupku, wyrastającej pomiędzy liśćmi akantu. W tle wolut widoczny jest cylinder trzonu kapitela o górnej krawędzi wyprofilowanej w kształcie okalającej listwy. Płyta abakusa jest profilowana, o zakleśniętych bokach dekorowanych w połowie szerokości kwiatonem. W obu wypadkach akant został poddany daleko idącemu uproszczeniu i stylizacji, silniejszej w przypadku pomnika Wazówny. Oba kapitele różnią się też kształtem motywu zdobniczego w postaci dekoracji liściastej wspartej na wąskim profilowanym słupku. W kaplicy Kołudzkich 
stwierdzić, że zauważone różnice są kwestią innej interpretacji przyjętego wzoru (il. 43, 44).

Analogiczne w obu zabytkach motywy to podwieszone chusty układające się w festony, kokardy i spływy - w kaplicy Kołudzkich pod naczółkami ołtarza oraz na ścianach kaplicy (il. 2-5, 35, 36), w pomniku Wazówny w przyłuczach arkady; girlandy owocowo-listne - w Gnieźnie na ścianie obok ołtarza (i1. 34), w Toruniu pomiędzy zwojami wolut flankujących cokół nagrobka Wazówny; profilowane ramy - w środkowej części ołtarza pomiędzy kolumnami w kaplicy Kołudzkich, oraz rozbudowujące je uszaki wokół kartusza herbowego i wokół chust w portalu wiodącym do niszy grobowca Wazówny; półkoliście kształtowane profile z wąskimi, wypukłymi wolutami na brzegach w zwieńczeniu oraz uszakach ołtarza (il. 2, 3, 13, 18) oraz w zwieńczeniu portalu toruńskiego; nakładki z białego alabastru (il. 2, 3, 8); okragłe kaboszony (il. 13) czy też elementy ornamentu zwijanego - w Gnieźnie w formie alabastrowych konsolek pod uszakami ołtarza (il. 23), w Toruniu w kartuszu herbowym. Wszystkie wymienione motywy należą jednakże do ówcześnie szeroko stosowanych, choć na podkreślenie zasługuje fakt, że w omawianych dziełach zestaw jest podobny, występują one jednocześnie, dodatkowo z zastosowaniem analogicznych elementów architektonicznych.

Odmiennie w obu zabytkach kształtuje się problem plastyki figuralnej - w pomniku grobowym Wazówny jest ona na znacznie wyższym poziomie artystycznym. Szczególnie dotyczy to rzeźb portalowych, a może być wynikiem zaangażowania do tej prestiżowej, królewskiej realizacji rzeźbiarza o specjalnych umiejętnościach. Następnym pytaniem, jakie się w tej kwestii nasuwa, jest to, czy można więc mówić o udziale w toruńskim dziele warsztatu zaangażowanego w kaplicy Kołudzkich i jaki ewentualnie mógł być mimo zauważalnej różnicy jakości - udział tego warsztatu w realizacjach figur w pomniku grobowym królewny Anny. Pomoc w wykonaniu projektu, współpraca przy kształtowaniu szat czy też wszelkich mniej widocznych partii rzeźby? Ku takim sądom skłania zaobserwowane pewne podobieństwo techniki pracy, być może powszechnie wówczas w warsztatach lub w tym

zyskały one wydłużoną, węższą, od wewnątrz rozczłonkowaną małymi listkami forme, w portalu toruńskim zaś są to znacznie rozbudowane w poziomie formy składające się jakby z trzech rozłożystych liści (il. 43, 44). 
warsztacie stosowane. W wyniku przewidywania sposobu widzenia rzeźby zauważalne jest niestaranne traktowanie niewidocznych jej partii, lub też całkowite niemal nieukończenie, pozostawienie w fazie wstępnego rozplanowania (w ołtarzu, il. 26). W związku z tym dzisiejszy „nieprzewidziany odbiorca”, jakim jest historyk sztuki, zauważa w obu przypadkach ślady wstępnego przycięcia bloku do prostych, zgeometryzowanych zarysów - w kaplicy np. w figurze anioła na lewym naczółku (fragment rękawa, il. 25), w portalu Wazówny w przypadku opracowania prawej, mniej widocznej, strony figury na lewym naczółku (np. sposób cięcia kamienia w partii szaty z prawej strony, il. 45) lub ewidentnie w górnej części figury Wazówny od strony ściany niszy $^{51}$. Warto też zwrócić uwagę na sposób potraktowania fragmentów drobniejszych, bardziej narażonych na zniszczenie lub też wymagających większej precyzji w cięciu kamienia, takich jak np. palce dłoni lub części atrybutu. Są one w obu zabytkach złączone $\mathrm{z}$ większym elementem przyległym, jak np. palce wskazujący i środkowy prawej dłoni figury po lewej stronie ołtarza w kaplicy Kołudzkich (il. 15) oraz złączone z blokiem kamienia, z którego wydobywano cała postać, palce lewej dłoni toruńskiej figury portalowej na lewym naczółku czy też zrośnięty z tłem, na którym się pojawia, dziób bociana, atrybutu tejże figury (il. 45). Kolejną cechą wspólną zauważalną w obu zabytkach jest „przyklejenie” szaty do ciała uwidaczniające na pewnym odcinku dość ściśle jego budowę - w ołtarzu gnieźnieńskim w partii podudzia prawej nogi postaci po prawej stronie (il. 18, 20), w pomniku Wazówny w partii prawego uda postaci po lewej stronie portalu oraz lewego postaci po stronie przeciwnej lub też w partii obu nóg figury Anny Wazówny. Uwagę zwraca też specyficzne potraktowanie rąk niektórych rzeźb, np. prawej postaci po lewej stronie ołtarza (il. 13) oraz rąk leżącej figury Wazówny, które są jakby „doklejone”, mimo tego, że są one wyczuwalne pod szatą skrywającą ich górną partię.

51 Ilustracje przedstawiające toruński pomnik grobowy Anny Wazówny znajdują się m.in. w nastepujących publikacjach: A. Saar-Kozłowska, Infantka Szwecji i Polski. Anna Wazówna 1568-1625. Legenda i rzeczywistość, Torun 1995; eadem, Napisy na pomniku grobowym królewny Anny Wazówny w kościele Wniebowzięcia Najświętszej Marii Panny w Toruniu. Pytanie o granice interpretacji, [w:] Inskrypcje toruńskie, pod red. I. Sawickiej, Toruń 1999, s. 115-165. 
Wymienione powyżej cechy mogą charakteryzować sposób pracy warsztatu, który mógł wziąć udział w wykonaniu obu zabytków. Jest to oczywiście hipoteza, która wymaga szerszego rozpoznania warsztatu i dalszych, szeroko zakrojonych studiów, ale może stać się zalążkiem lub podstawą przyszłych wnioskowań. Przeciwko hipotezie o pracy jednego warsztatu w obu zabytkach, a za przyjęciem tezy, że poznajemy jedynie typowe wówczas metody pracy oraz charakterystyczne nastawienie na rzeźbiarskie precyzowanie wyłącznie widocznych partii rzeźb przemawia nie tylko kwestia wyższej jakości artystycznej plastyki figuralnej toruńskiego zabytku, głównie figur portalowych, ale też fakt ich ścięcia z tyłu, powstałego zapewne z myślą o umieszczeniu przy ścianie, oraz ich znaczne od tej ściany odsunięcie, tak jakby wykonawca rzeźb nie do końca zdawał sobie sprawę z przestrzeni istniejącej na częściach naczółka portalu (dotyczy to również leżącej figury zmarłej).

W kontekście powyższych rozważań należy wspomnieć tu o jeszcze jednym zabytku, a mianowicie o ołtarzu Opłakiwania z kościoła św. Mikołaja w Gdańsku (1662), przypisanym przez Janusza Pałubickiego Wilhelmowi Richterowi ${ }^{52}$. Jego konstrukcja architektoniczna w zasadzie powtarza układ portalu grobowca królewny Anny Wazówny (około 1636). Analogiczna jest kompozycja w formie łuku triumfalnego oraz między innymi stojące na cokołach kolumny z bazą umieszczoną na płycie i kapitelem korynckim, towarzyszące kolumnom od strony zewnętrznej połówki pilastrów, przechodząca pod kolumną (także w ołtarzu gnieźnieńskim) i przez półpilaster forma listwy stanowiącej podstawę łuku arkady, przerwany naczółek z nastawą pomiędzy jego cześciami z wydzieloną profilowaniem ramą z uszakami, spiętrzone w trójkątnej formie zwieńczenie, trójdzielne belkowanie dźwigane przez kolumny, figury na częściach naczółka, motywy chust itp. Oczywiście, kompozycja podobna do toruńskiego portalu została dostosowana do wymogów konstrukcji ołtarza oraz, co istotne, zabytek ma bardziej niderlandyzujący charakter. Więcej jest elementów geometrycznych o białej barwie, a całość zyskała silniejszy graficzny wyraz niż w przypadku toruńskiego zabytku. Można zaryzykować stwierdzenie, że projekt przygotowany dla pomnika grobowego Wazówny (przed 1636) posłużył do wykonania innych dzieł w tym

52 J. Pałubicki, Marmurowa rzeźba, s. 74, 104, il. 71. 
samym warsztacie (?), a mianowicie ołtarzy Opłakiwania (il. 46) w kościele św. Mikołaja w Gdańsku (1662) oraz w kaplicy Kołudzkich w Gnieźnie (przed 1652). W tej sytuacji należałoby zapytać o przyczyny takich zbieżności. Tu pojawia się kolejna możliwość postawienia hipotezy atrybucyjnej. Otóż wysoce prawdopodobne jest, że poddany analizie warsztat brał udział w wykonaniu wszystkich trzech dzieł, a przede wszystkim ich elementów architektonicznych oraz architektonicznego detalu. W przypadku zabytku toruńskiego mogła to być realizacja zleconego projektu, który mógł pochodzić od jednego z artystów związanych z dworem króla Władysława IV, a spośród nich być może od Giovanniego Battisty Ghisleniego, na co zdaje się wskazywać np. jego rysunek dekoracji na pogrzeb Karola Ferdynanda Wazy w kościele Jezuitów w Warszawie (1655). Projekt zabytku toruńskiego zaowocował stworzeniem dzieła bardziej w stylu sztuki italianizującej, bardziej plastycznej, o ograniczonej liczbie różnokształtnych elementów o barwie białej, rozbijających formę zasadniczo opracowaną w czerni. Można stwierdzić, że im dalej od pierwowzoru, tym silniej uwidoczniły się w działalności warsztatu elementy sztuki północnej, charakterystyczne dla warsztatów gdańskich.

Wszystkie dalsze studia atrybucyjne, których kierunek został powyżej określony, przekraczają już zakres tej publikacji. Na koniec należałoby zapytać, jaki warsztat był przedmiotem podjętej próby rozpoznajacej analizy. Z dużą dozą prawdopodobieństwa można naszym zdaniem przyją́, że badane były pochodzące $z$ różnych etapów działalności wytwory gdańskiego warsztatu, być może właśnie Wilhelma Richtera. Prawdopodobne jest też, że w przypadku pomnika grobowego Wazówny warsztat ten realizował powierzony projekt, szczególnie w zakresie elementów architektonicznych. Najprawdopodobniej powyższy tekst jest przyczynkiem do rozpoznania cech owego warsztatu, którego skład mógł być zmieniany w zależności od skali i rangi zlecenia. W przypadku kaplicy Kołudzkich możliwe jest także rozważenie podzlecenia wykonania niektórych prac (rzeźb apostołów i siedzących aniołów?) nieznanemu nam warsztatowi (lokalnemu?). Do kwestii tej można będzie powrócić wtedy, gdy powstaną inne opracowania formy dzieł architektoniczno-rzeźbiarskich zabytków ziem polskich powstałych w XVII wieku, oparte na bogatej dokumentacji fotograficznej. 
Wiadomo, że wnikliwe badania historyka sztuki nad analizą stylistyczną i warsztatową dzieł, prowadzące do wysunięcia hipotezy atrybucyjnej, wymagają rzetelnej pracy przy obiekcie i bardzo dobrej dokumentacji fotograficznej ${ }^{53}$.

Atrybucje zaproponowane na podstawie zbyt powierzchownych studiów blokują prace innych badaczy. Na pewnym etapie konieczna była i wystarczała w zasadzie znakomita często intuicja i ogromna wiedza dawnych uczonych. Dziś chyba nadszedł czas na powrót do podjętych przez nich badań, na rozwinięcie interesujących ich wątków, postawionych hipotez i próbę rzetelnej rewizji ich sądów na podstawie dorobku w dziedzinie badań szczegółowych i możliwości technicznych dokumentacji, jakich dawni badacze nie mieli!

To, co zostało tu fragmentarycznie przedstawione, jako próba przeprowadzenia analizy formy rzeźbiarskiego wyposażenia kaplicy Kołudzkich, jest efektem poszukiwania modelu dla własnych badań atrybucyjnych dotyczących szerszego kręgu zabytków. Jeśli skonfrontuje się ten system z wynikami dotychczasowych ustaleń, nieraz okazuje się, że właściwie studia trzeba rozpoczać od nowa. Tak, przynajmniej naszym zdaniem, należy postąić w przypadku zabytków gnieźnieńskich. Z pomocą przychodzi nam fotografia cyfrowa, stwarzająca szansę tworzenia od nowa szczegółowych baz danych. Bez systematycznego ich gromadzenia i udostępniania w wersji cyfrowej i publikowanej tradycyjnie rozpoznanie obrazu polskiej rzeźby nowożytnej jest niemożliwe.

53 W Instytucie Zabytkoznawstwa i Konserwatorstwa dobrą sytuację do takich badań stworzyła wieloletnia działalność pracowni Dokumentacji Fotograficznej, którą przez długi czas prowadził Pan mgr Wacław Górski, dziś emerytowany. On to „zdjął” ze ścian, sklepień, portali tysiące zabytków, które trafiły na stół pracy historyka sztuki. Przez wiele lat Pan Wacław współpracował z Panem Andrzejem Skowrońskim. W IZiK powstała też fototeka, umożliwiająca dostęp do efektów tej wieloletniej pracy. Wyrażając wdzięczność za to wszystko, reprezentuję nie tylko siebie. W IZiK dodatkowo sprzyjającą sytuację stwarza też możliwość wspólpracy z konserwatorami dzieł sztuki i wspieranie wyników analizy historyczno-artystycznej wynikami ich badań. Na potrzeby powyższej wypowiedzi korzystałam z dokumentacji konserwatorskiej dr. Piotra Niemcewicza, za co dziękuję. 
[50]

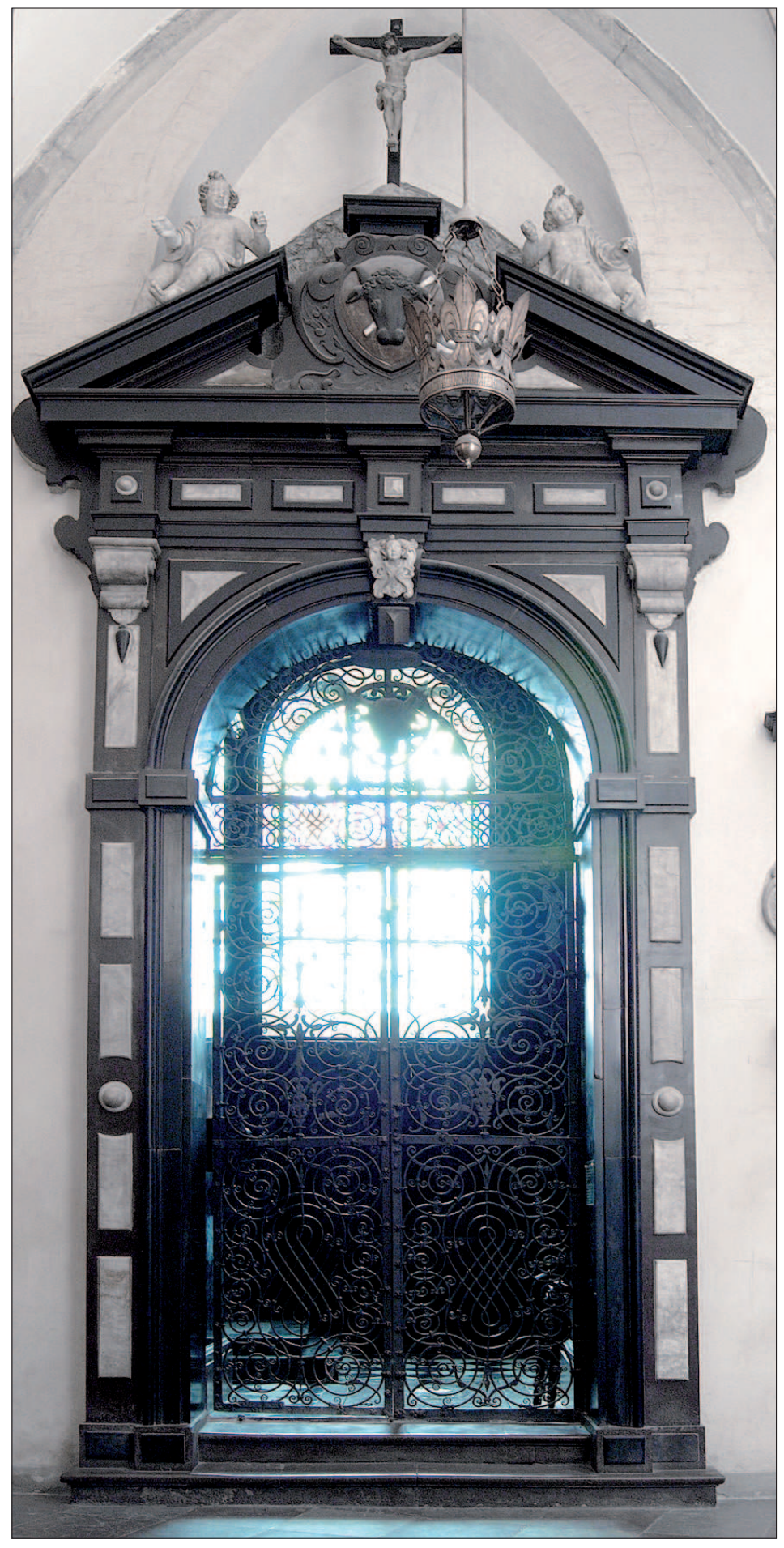

Il. 1. Portal kaplicy Kołudzkich w katedrze w Gnieźnie, ok. 1647 r., przed 1653 r. Widoczna krata została wykonana ok. 1650 r. z polecenia Szymona Kołudzkiego (fot. A. Skowroński) 


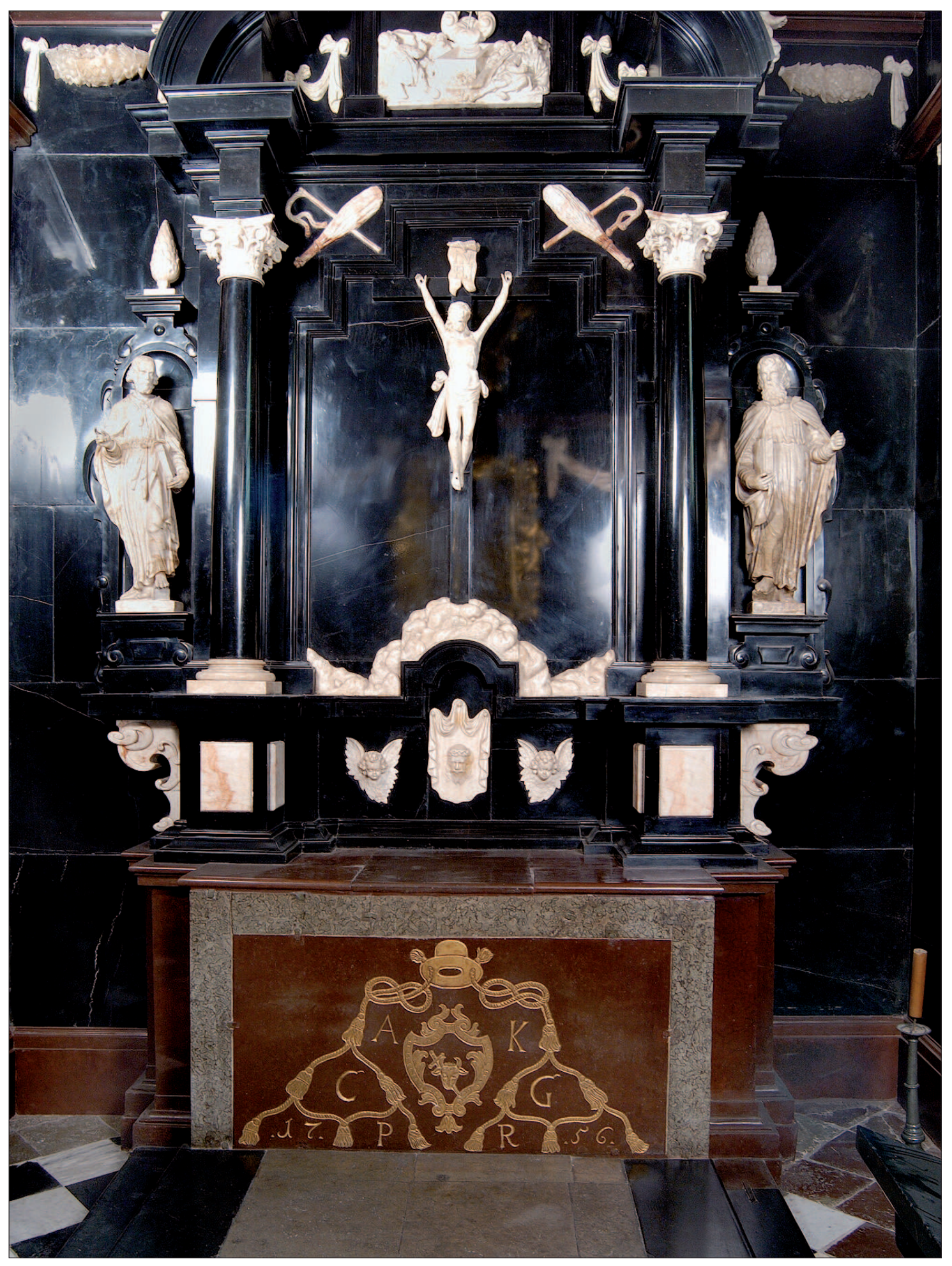

Il. 2. Ołtarz w kaplicy Kołudzkich w katedrze w Gnieźnie, po 1647 r., przed 1656 r. (?), fragment (fot. A. Skowroński) 
[52]

a)

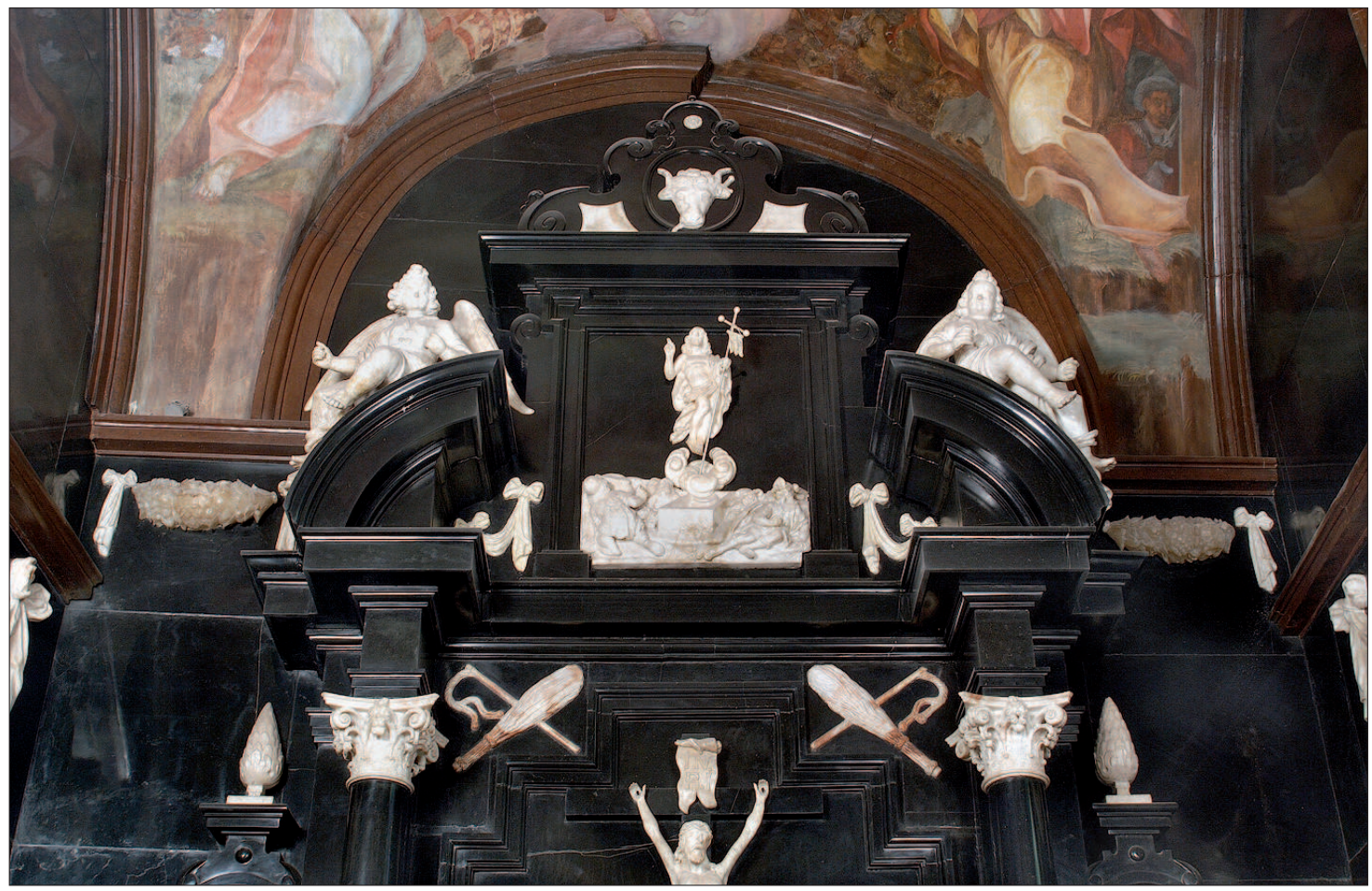

b)

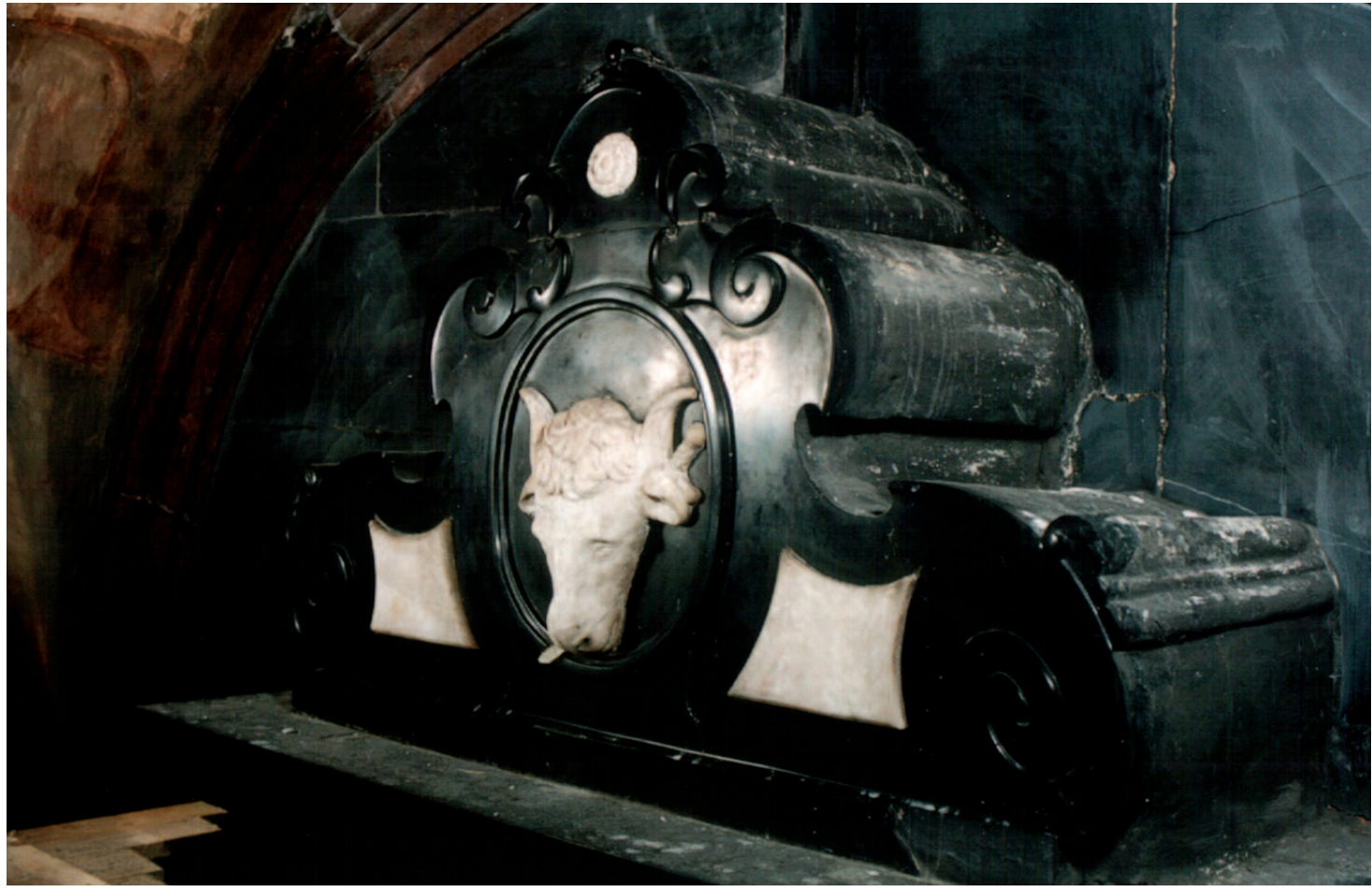

Il. 3. a) Ołtarz w kaplicy Kołudzkich w katedrze w Gnieźnie, fragment; b) zwieńczenie ołtarza z kartuszem herbowym (fot. A. Skowroński) 


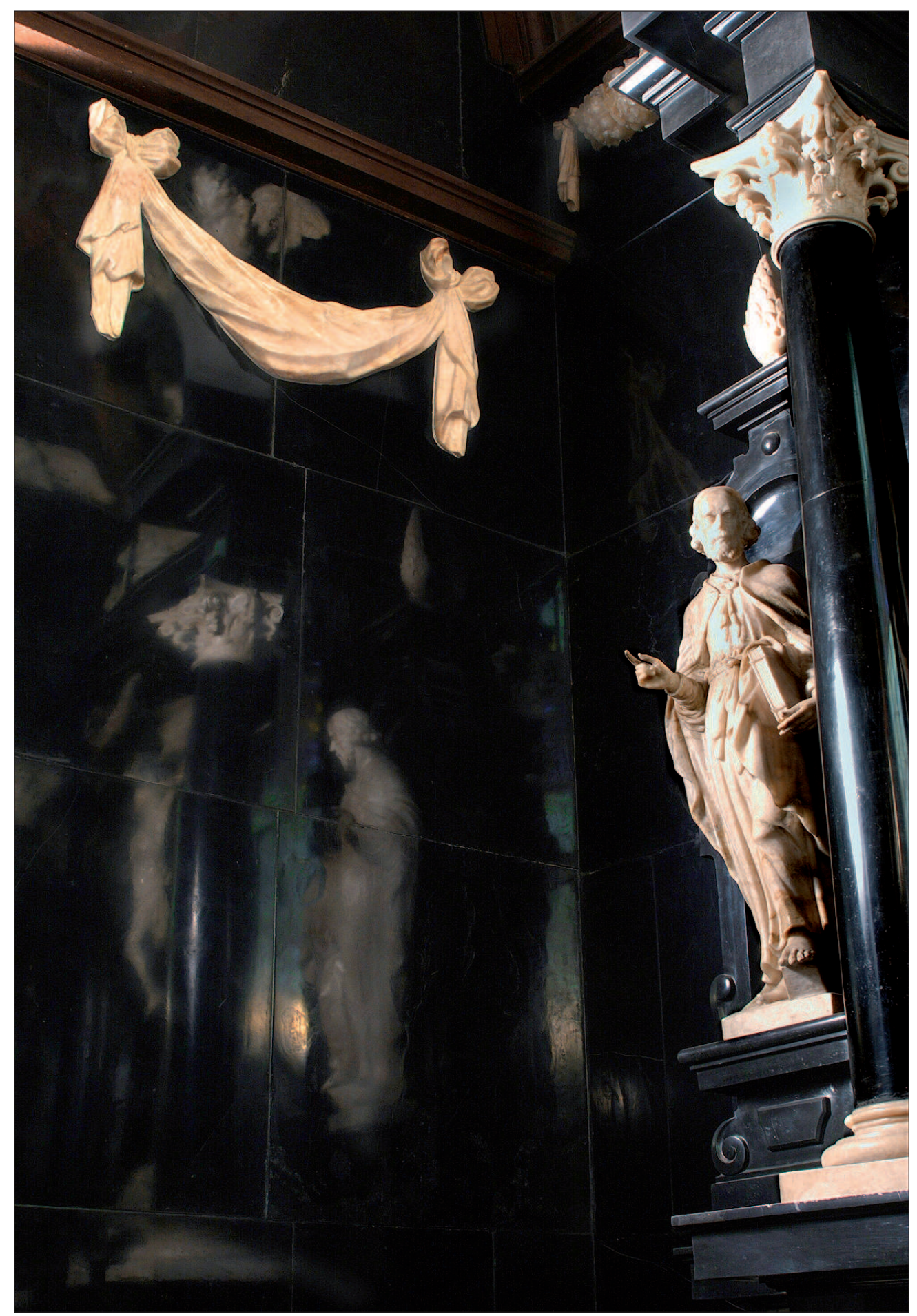

Il. 4. Ściana północna, wejściowa oraz fragment ołtarza w kaplicy Kołudzkich w katedrze w Gnieźnie. Widoczny jest efekt lustrzanego połysku ścian obłożonych czarnym marmurem oraz odbijania się w nich sąsiadujących partii ołtarza (fot. A. Skowroński) 


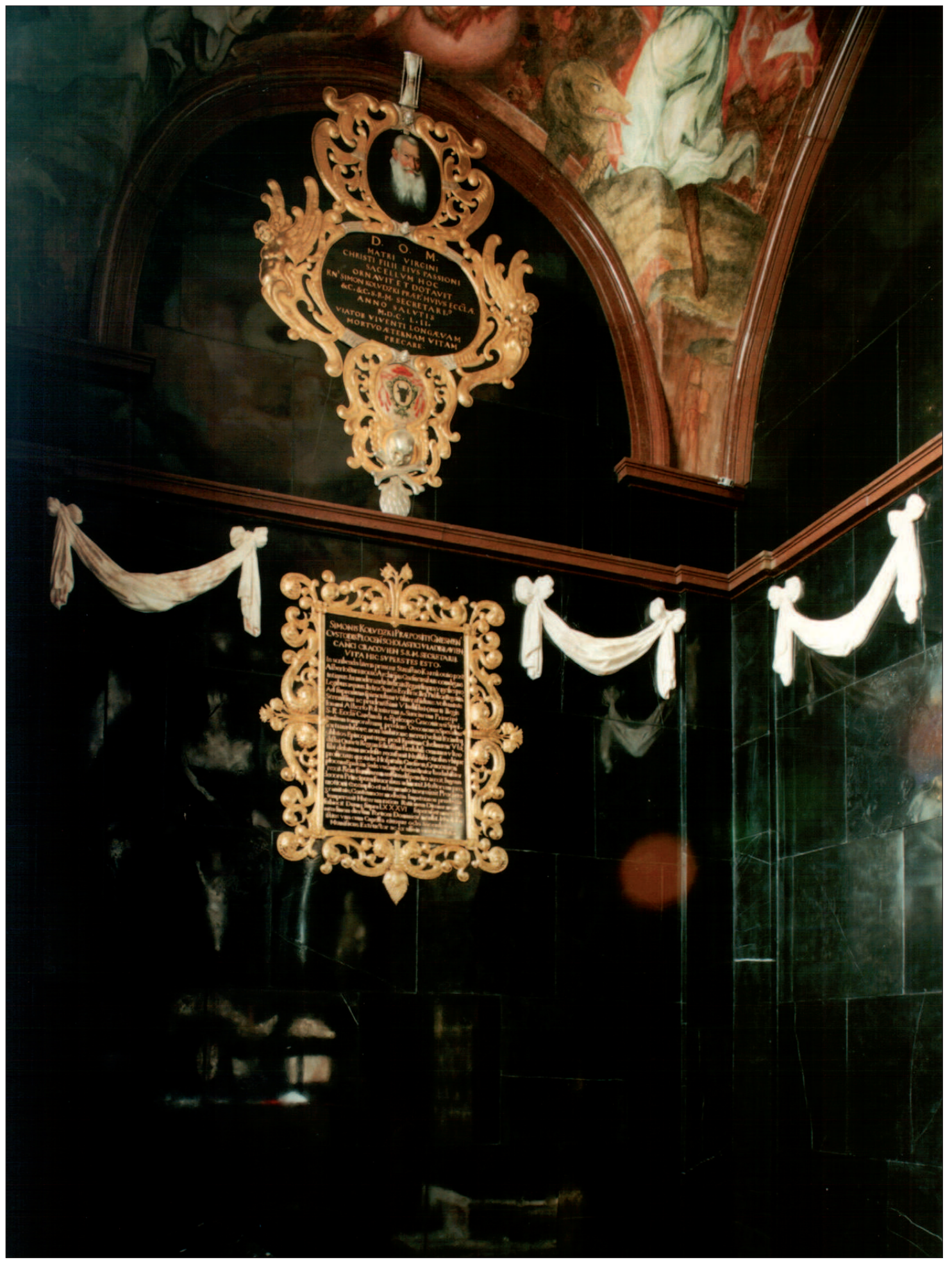

Il. 5. Tablica fundacyjna (1652 r.) oraz epitafium inskrypcyjne Szymona Kołudzkiego na ścianie zachodniej kaplicy Kołudzkich w katedrze w Gnieźnie (fot. A. Skowroński) 


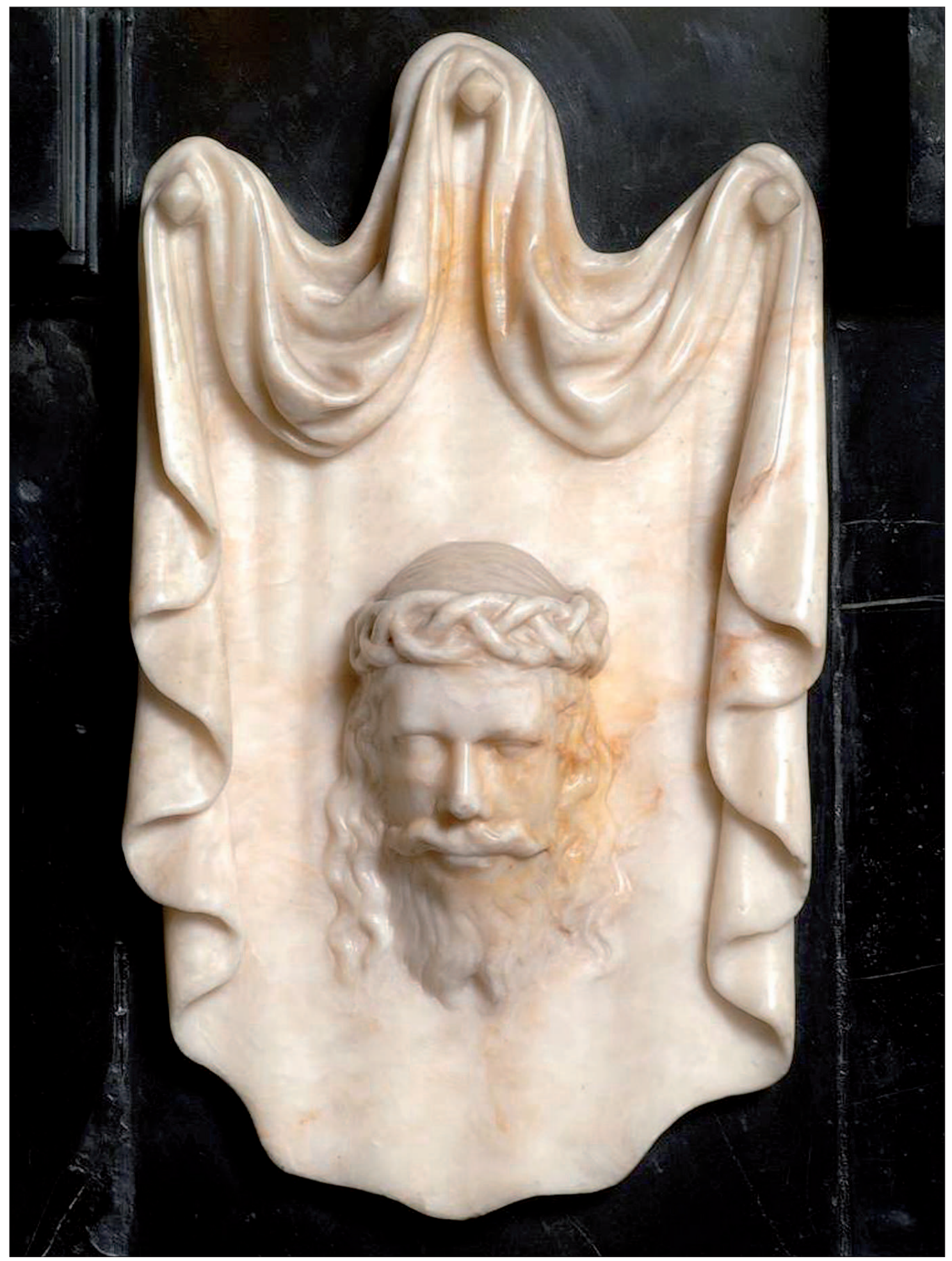

Il. 6. Płaskorzeźba chusty świętej Weroniki, fragment dekoracji predelli ołtarza w kaplicy Kołudzkich (fot. A. Skowroński) 
[56]

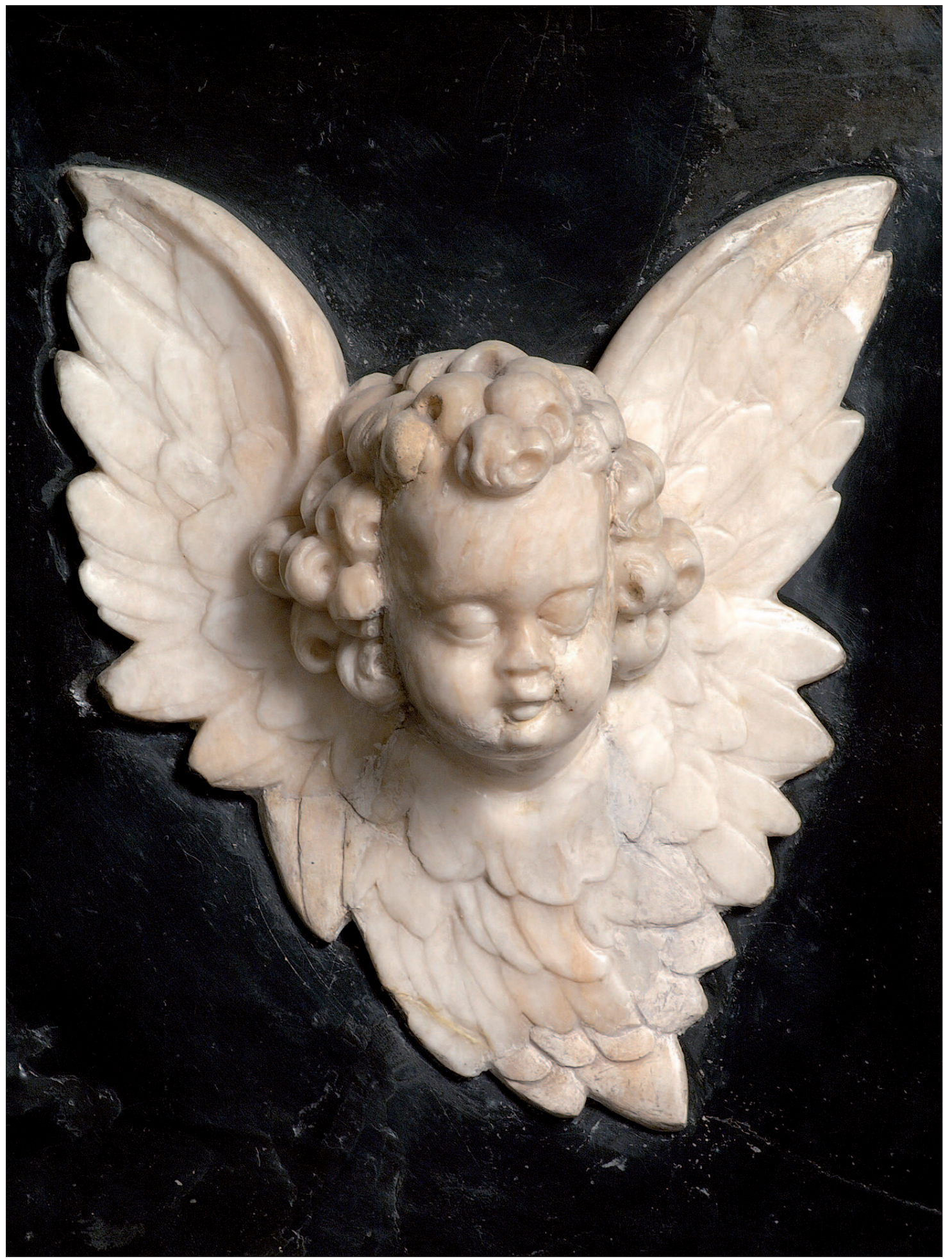

Il. 7. Uskrzydlona główka putta dekorująca lewą stronę predelli ołtarza w kaplicy Kołudzkich (fot. A. Skowroński) 


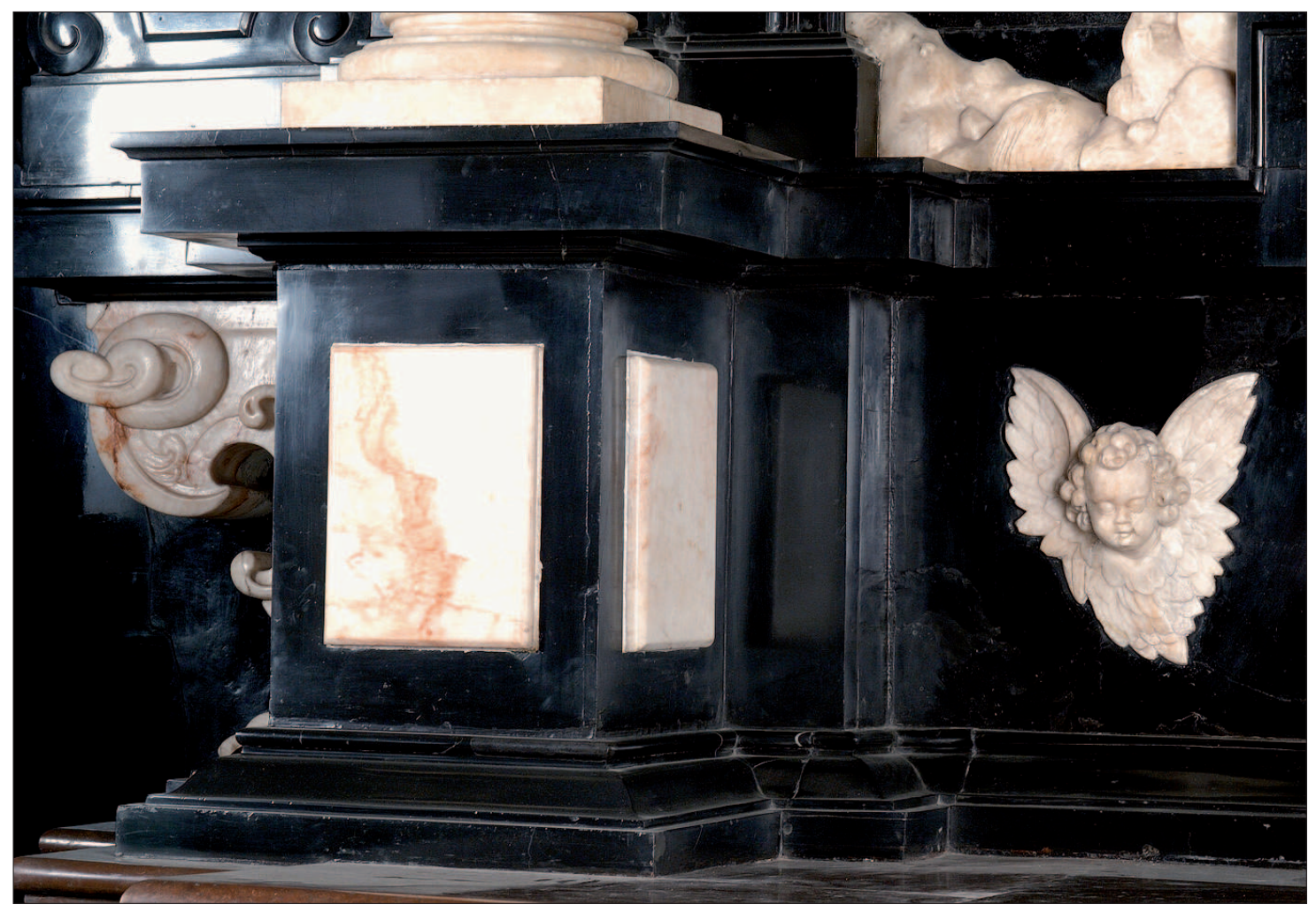

Il. 8. Fragment predelli ołtarza w kaplicy Kołudzkich (fot. A. Skowroński) 
[58]

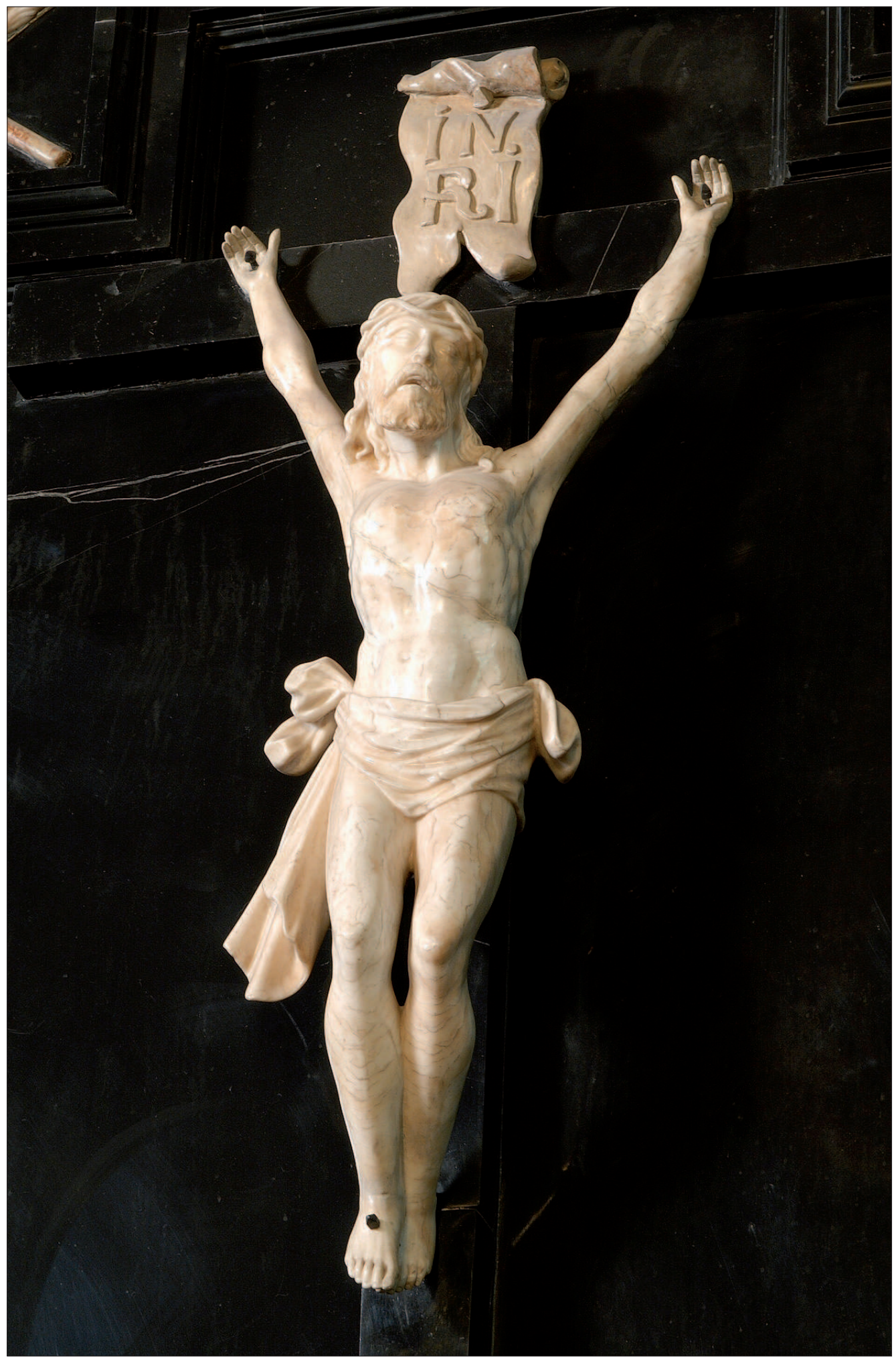

Il. 9. Rzeźba Chrystusa ukrzyżowanego w ołtarzu w kaplicy Kołudzkich (fot. A. Skowroński) 


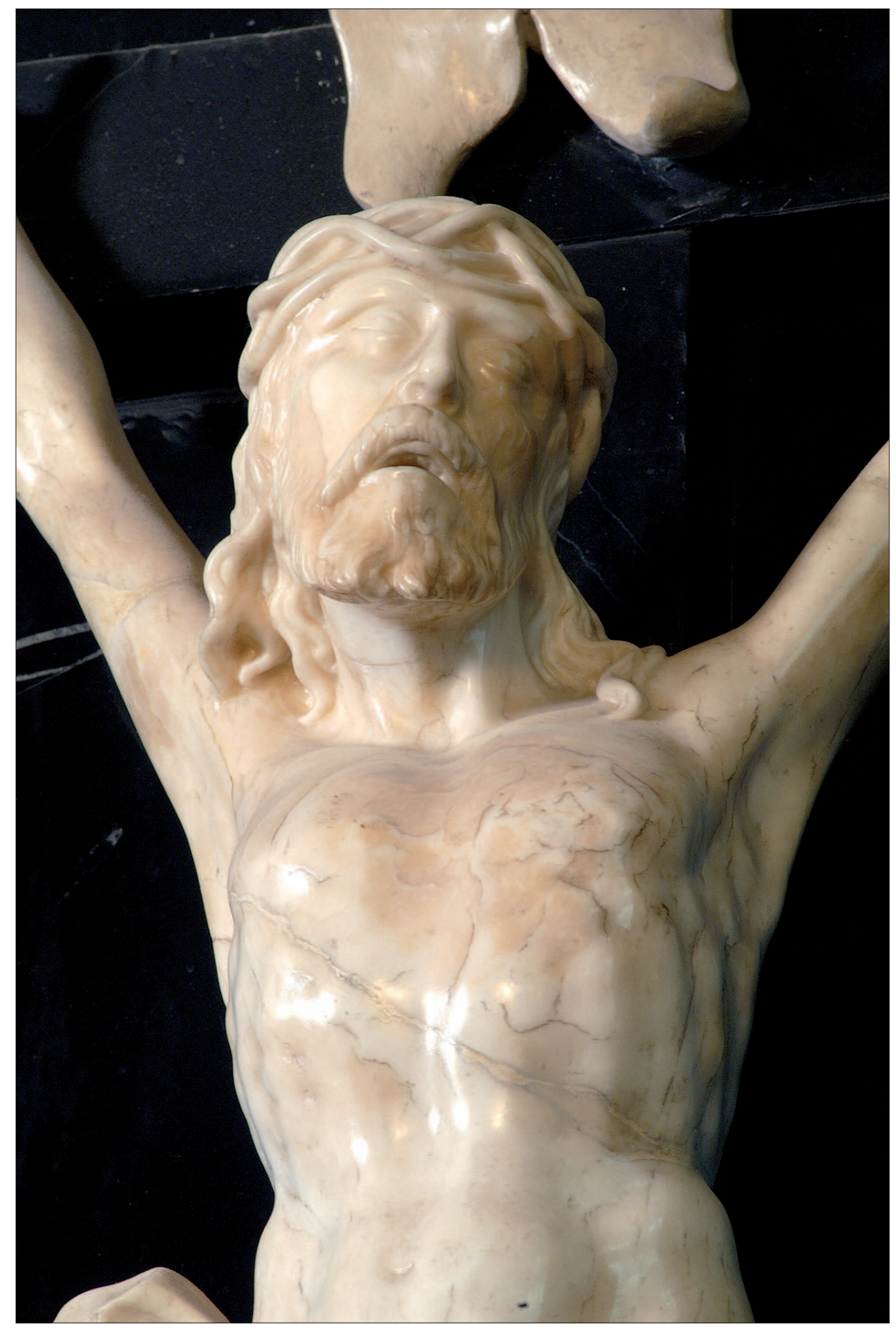

Il. 10. Fragment figury Chrystusa ukrzyżowanego w ołtarzu w kaplicy Kołudzkich (fot. A. Skowroński) 


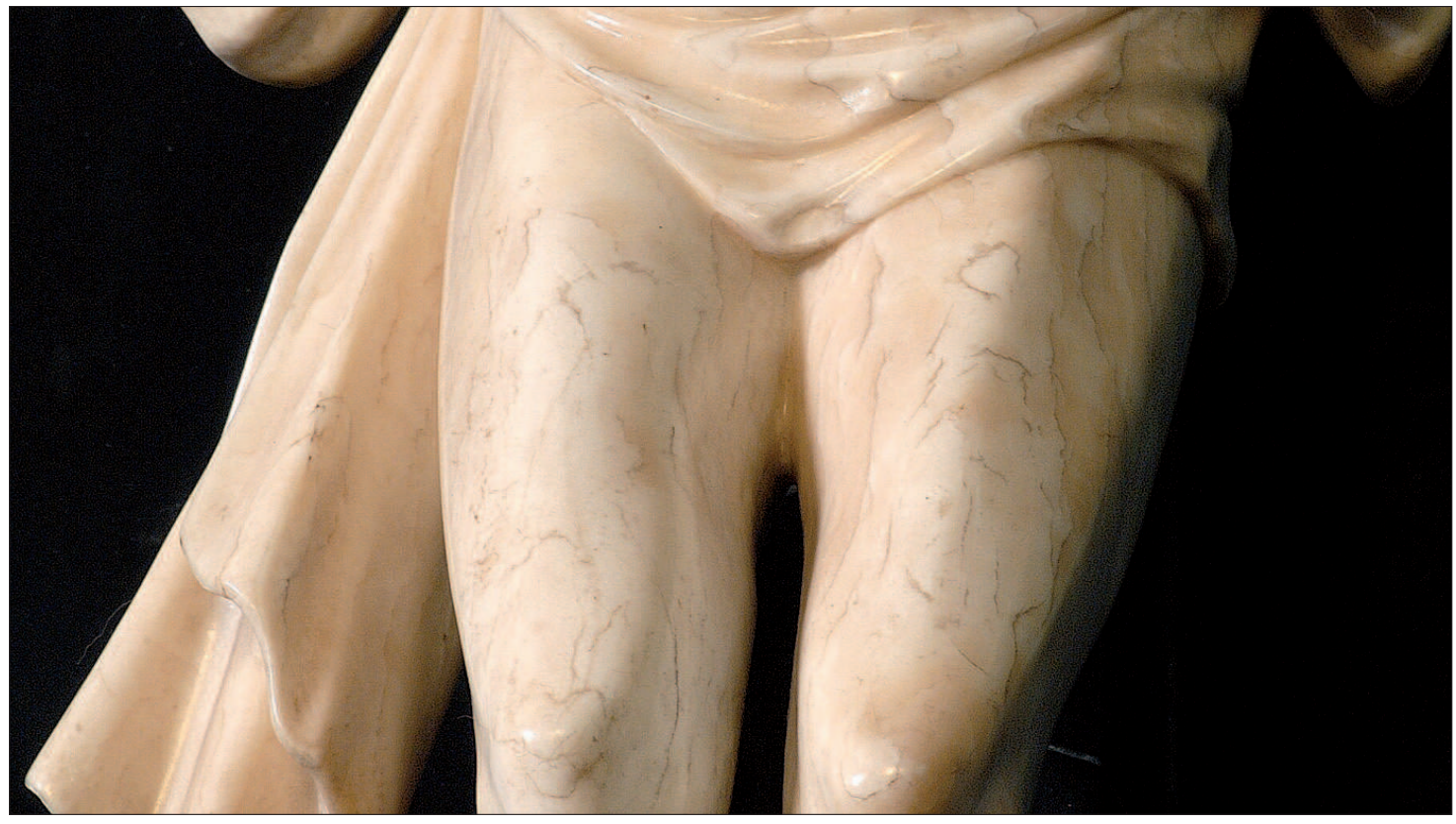

Il. 11. Fragment figury Chrystusa ukrzyżowanego w ołtarzu w kaplicy Kołudzkich (fot. A. Skowroński)

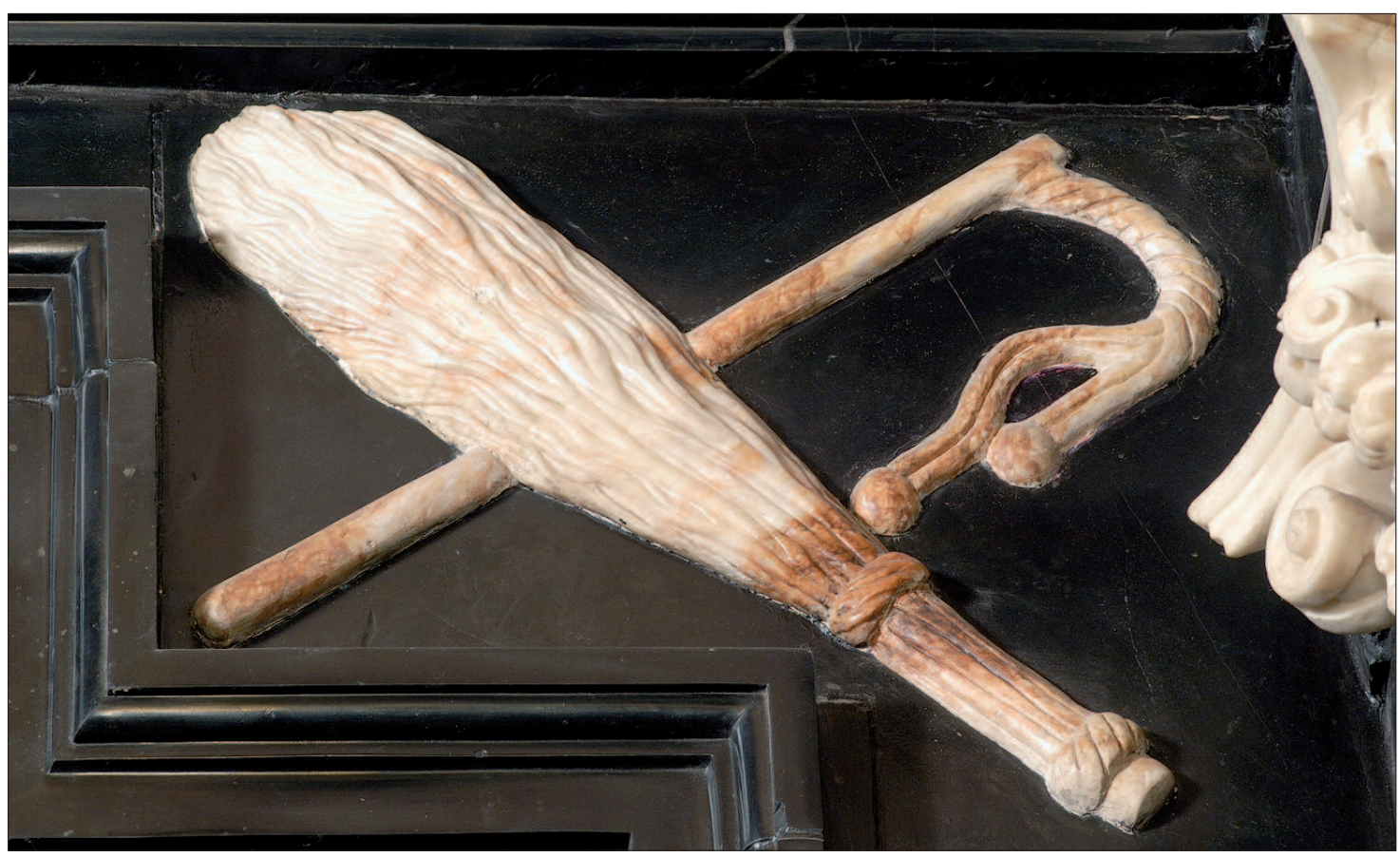

Il. 12. Arma Christi w ołtarzu w kaplicy Kołudzkich (fot. A. Skowroński) 


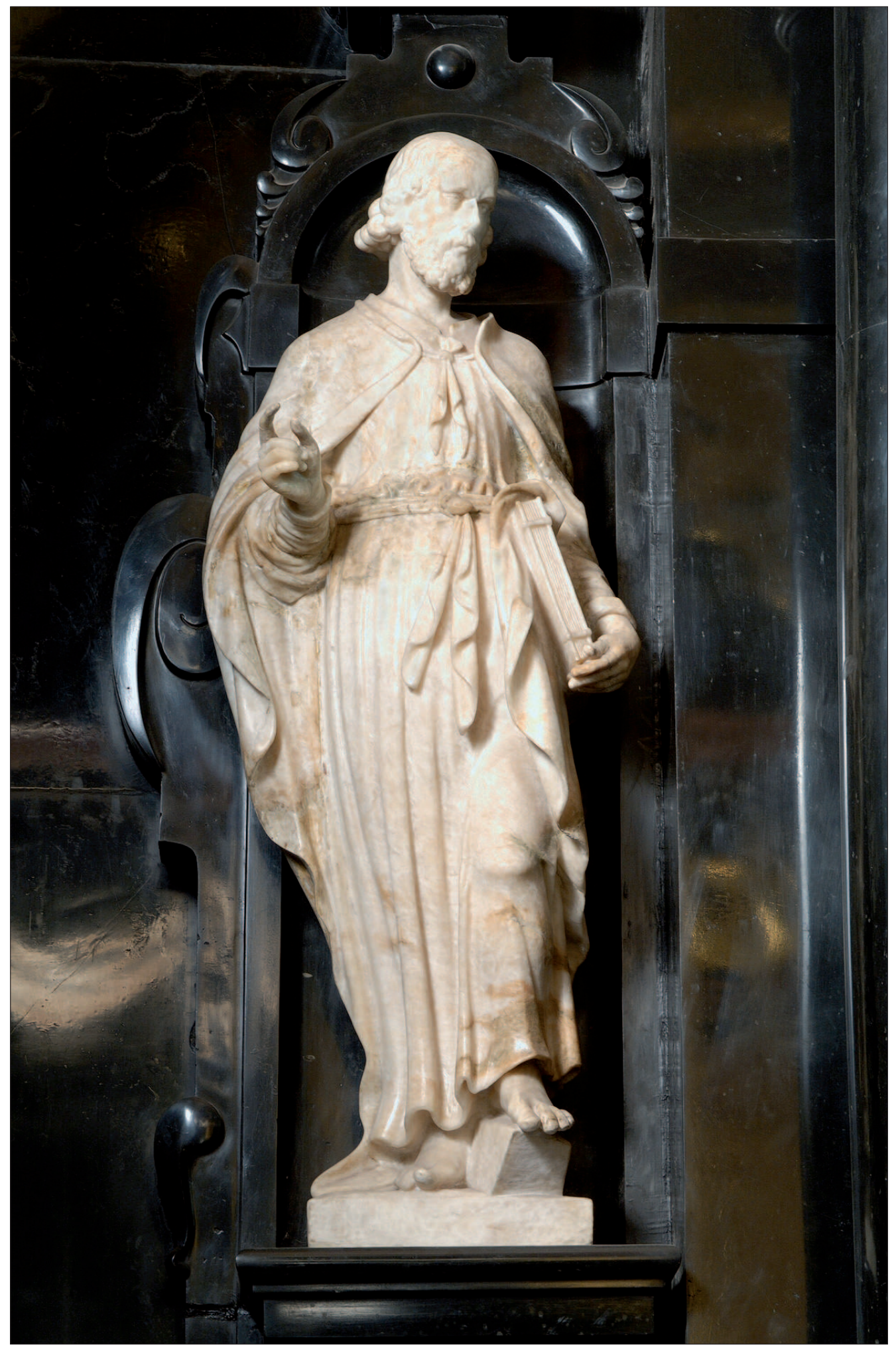

Il. 13. Figura apostoła po lewej stronie ołtarza w kaplicy Kołudzkich (fot. A. Skowroński) 


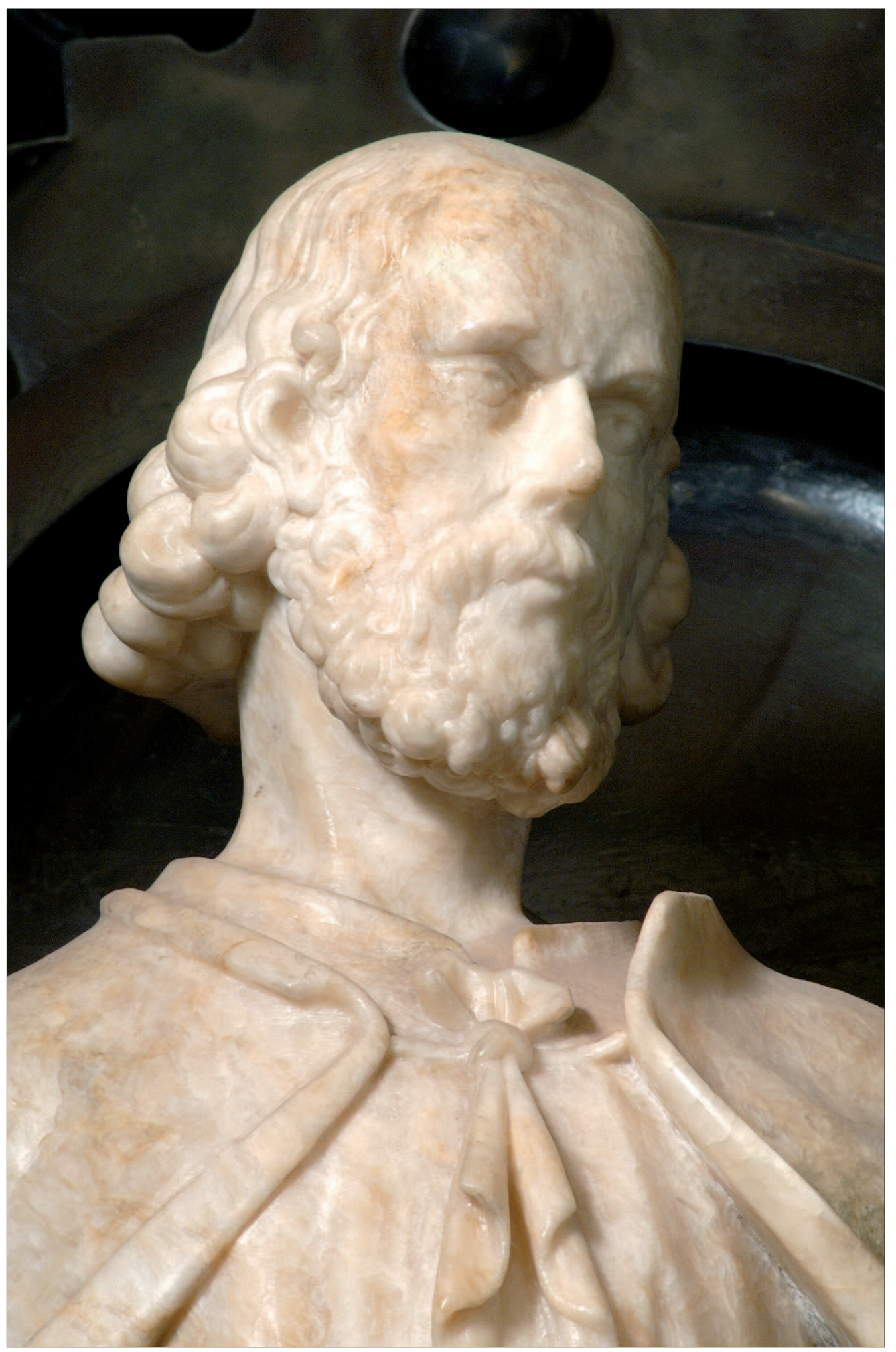

Il. 14. Figura apostoła po lewej stronie ołtarza w kaplicy Kołudzkich, fragment (fot. A. Skowroński) 


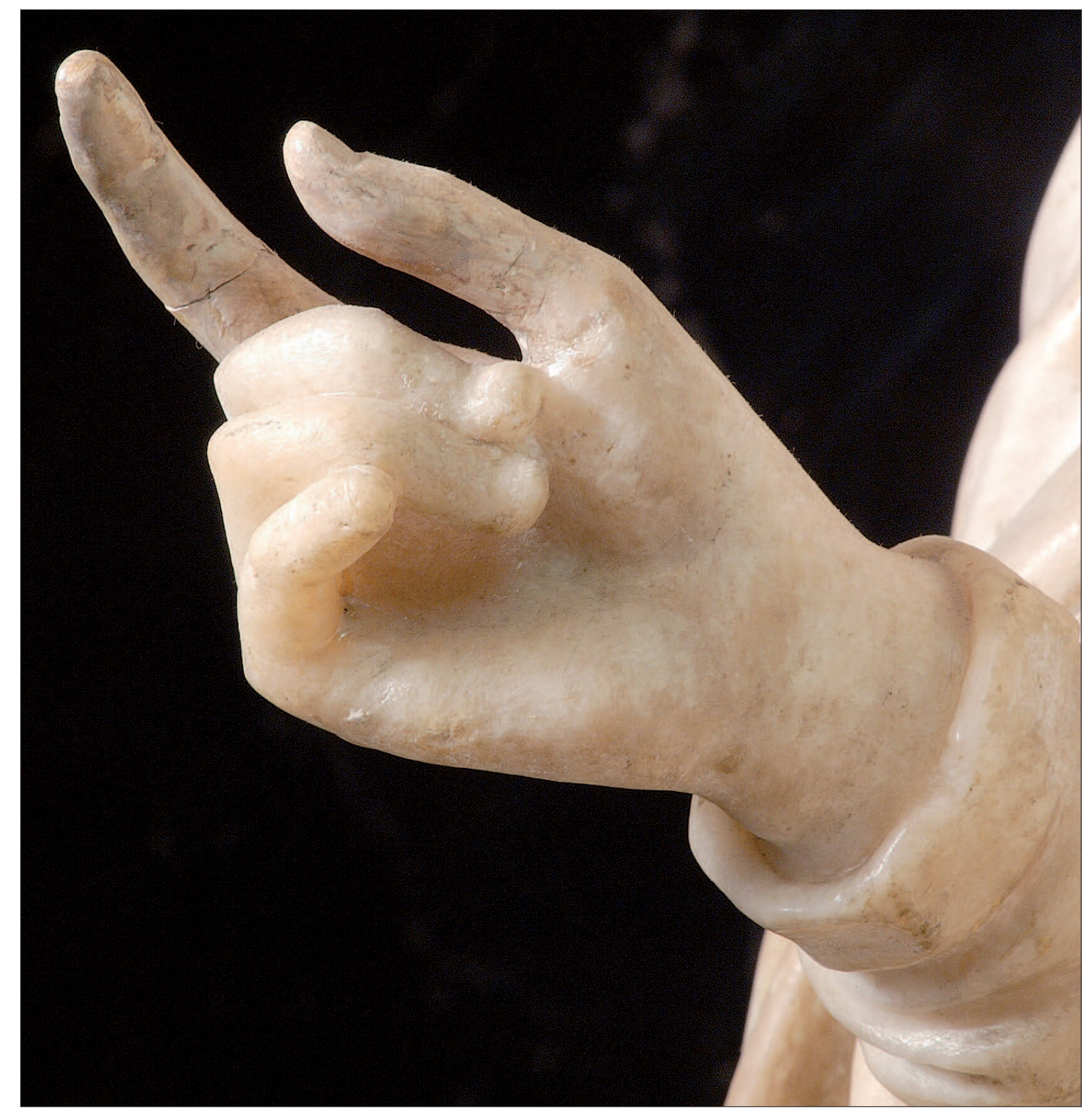

Il. 15. Fragment prawej ręki figury apostoła po lewej stronie ołtarza w kaplicy Kołudzkich. Palec wskazujący i kciuk są rekonstruowane. Widoczny sposób opracowania palców oraz połączenia dwu środkowych z blokiem marmuru, w którym wyrzeźbiono rękę (fot. A. Skowroński) 


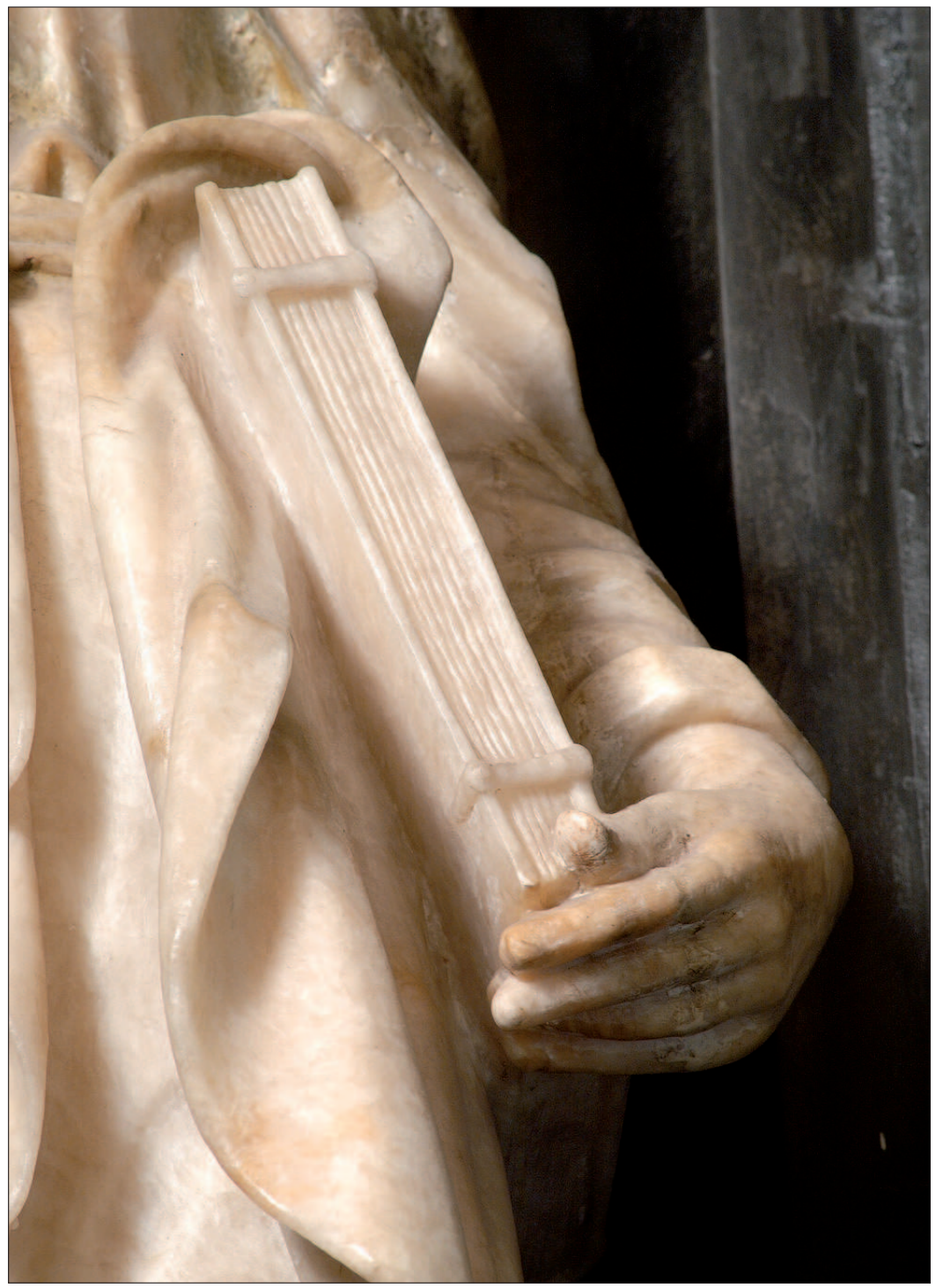

Il. 16. Fragment lewej ręki apo-

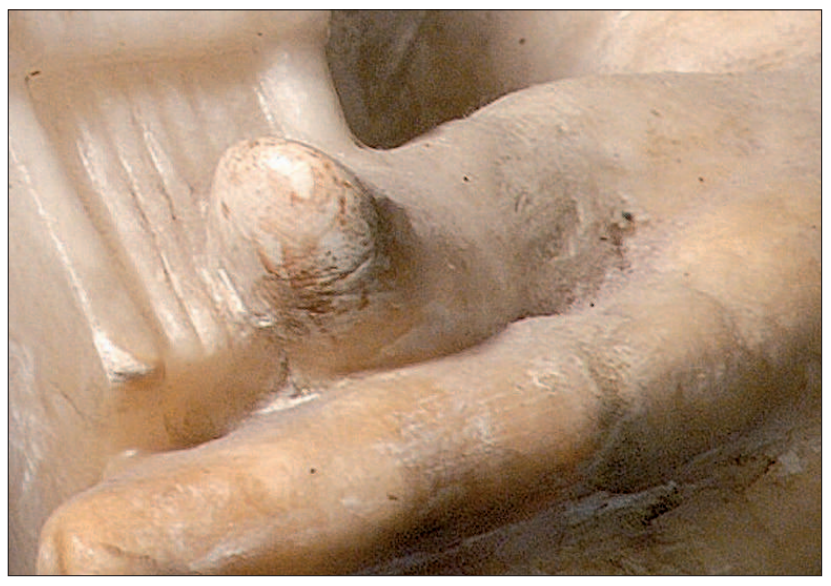
stoła po lewej stronie ołtarza w kaplicy Kołudzkich. Widoczny jest brak precyzyjnego rozdzielenia form ręki, księgi oraz szaty (fot. A. Skowroński)

\section{Il. 17. Fragment lewej reki} apostoła po lewej stronie ołtarza w kaplicy Kołudzkich (fot. A. Skowroński) 


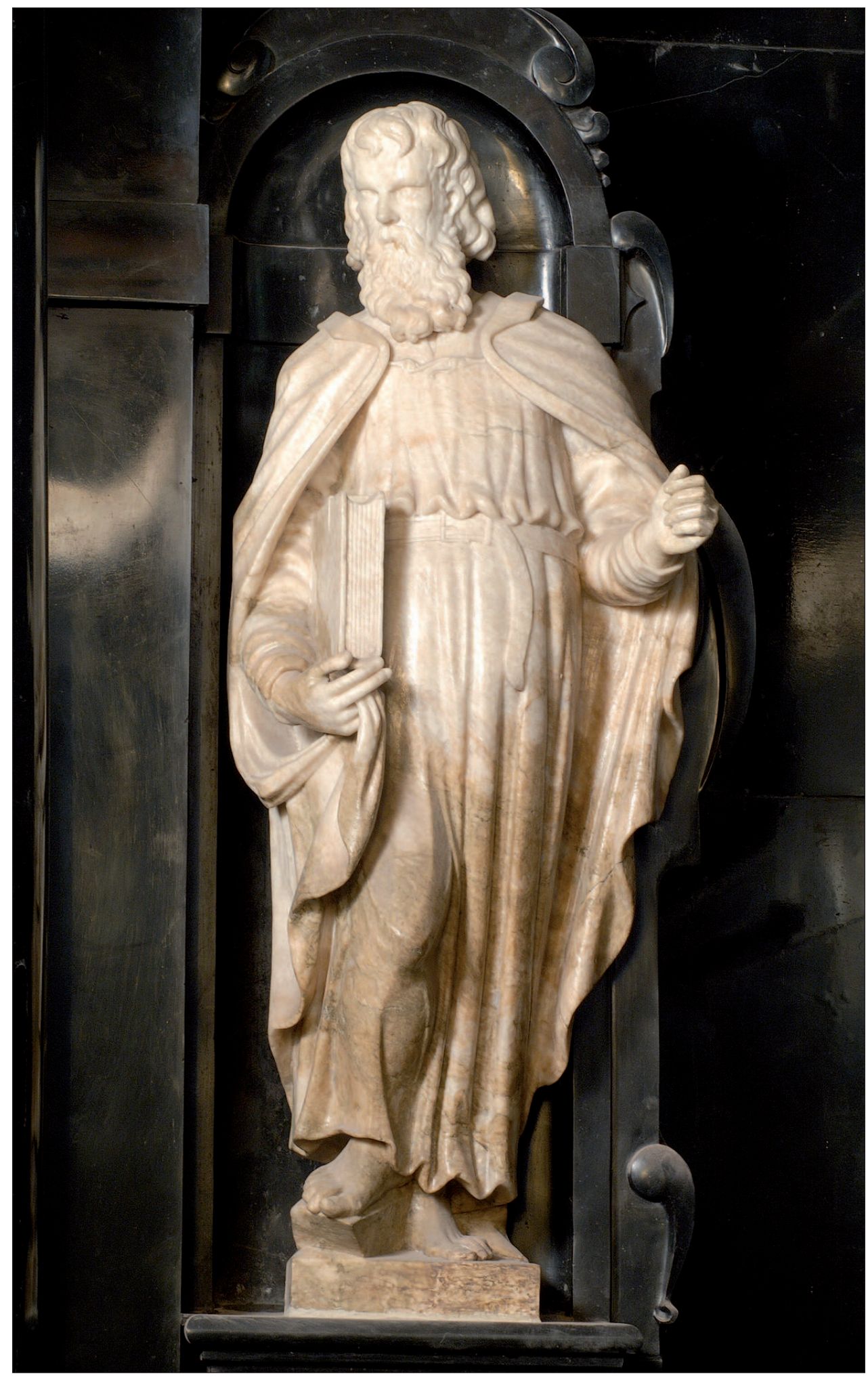

Il. 18. Figura apostoła po prawej stronie ołtarza w kaplicy Kołudzkich (fot. A. Skowroński) 


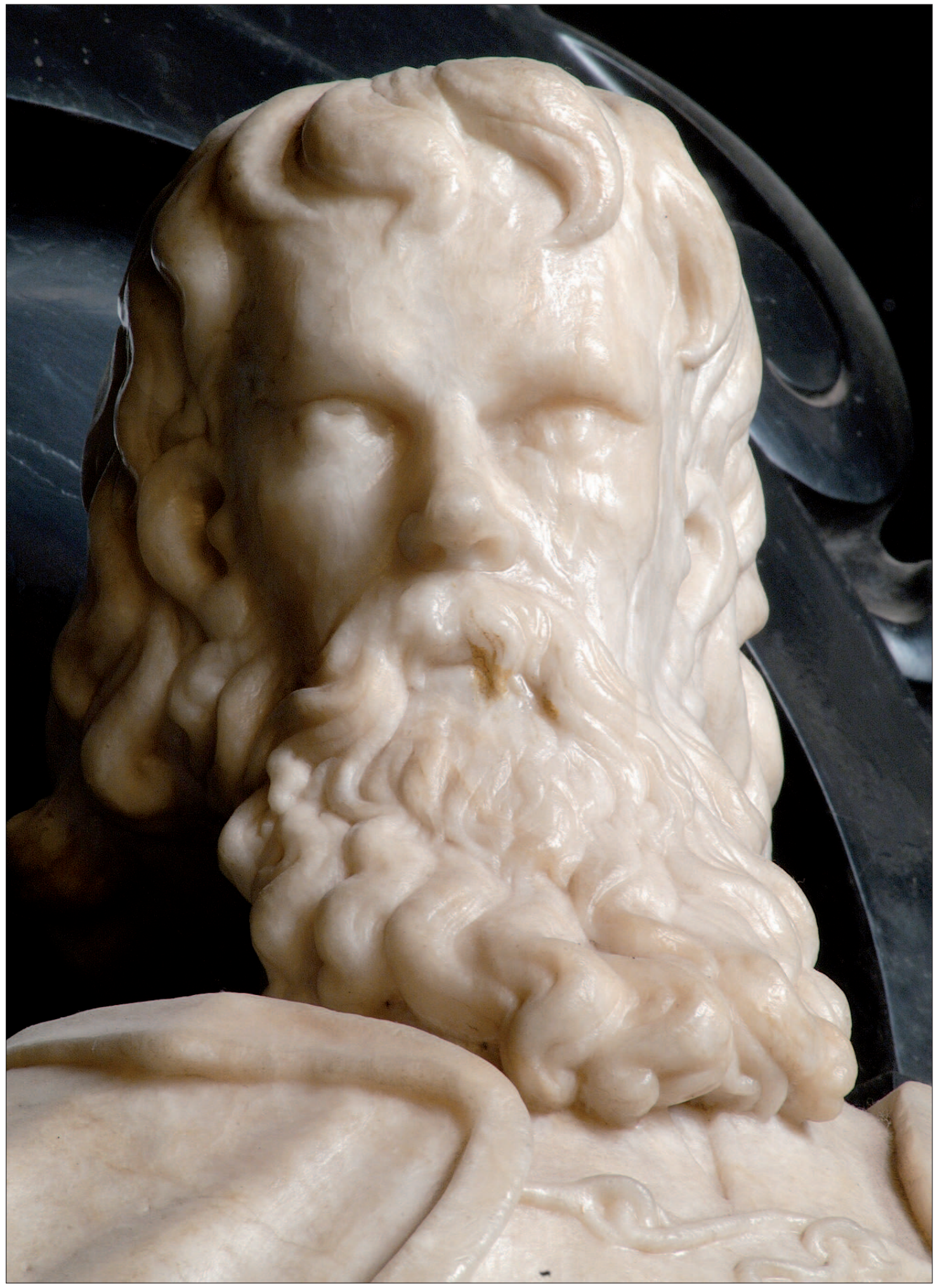

Il. 19. Figura apostoła po prawej stronie ołtarza w kaplicy Kołudzkich, fragment (fot. A. Skowroński) 

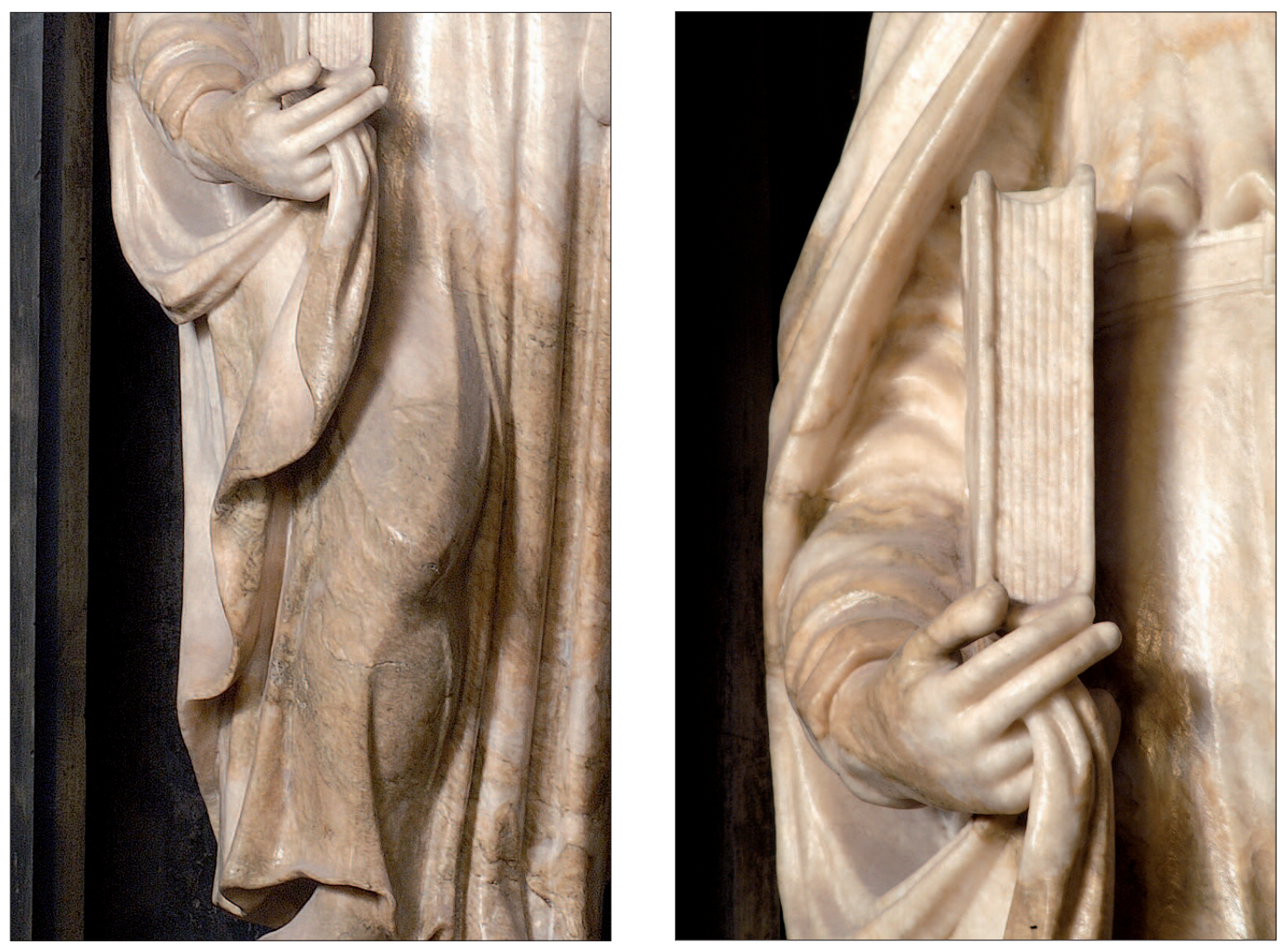

Il. 20, 21. Figura apostoła po prawej stronie ołtarza w kaplicy Kołudzkich, fragmenty (fot. A. Skowroński) 


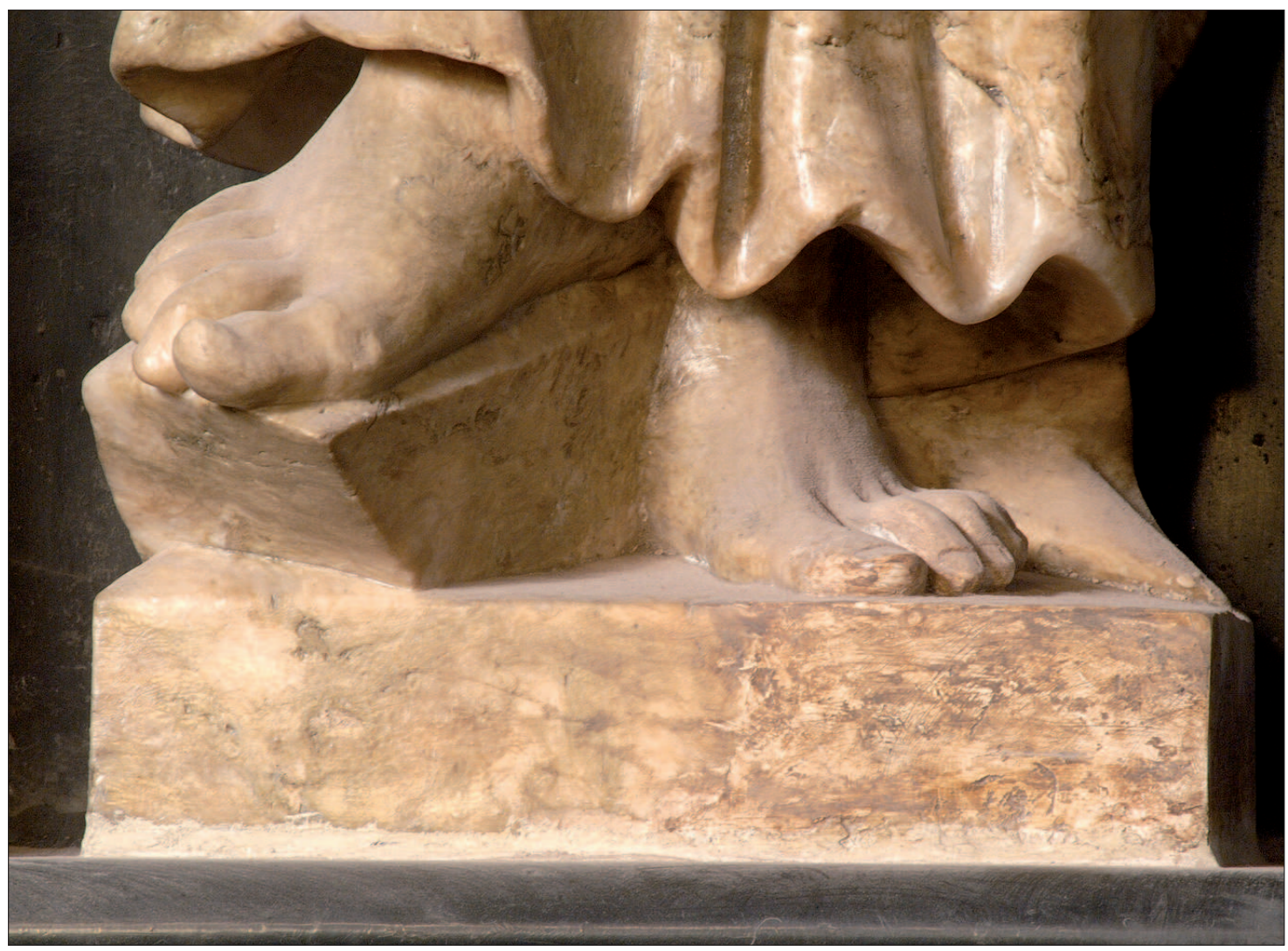

Il. 22. Figura apostoła po prawej stronie ołtarza w kaplicy Kołudzkich, fragment. Postument po prawej stronie i palec lewej stopy po prawej stronie to rekonstrukcje (fot. A. Skowroński) 


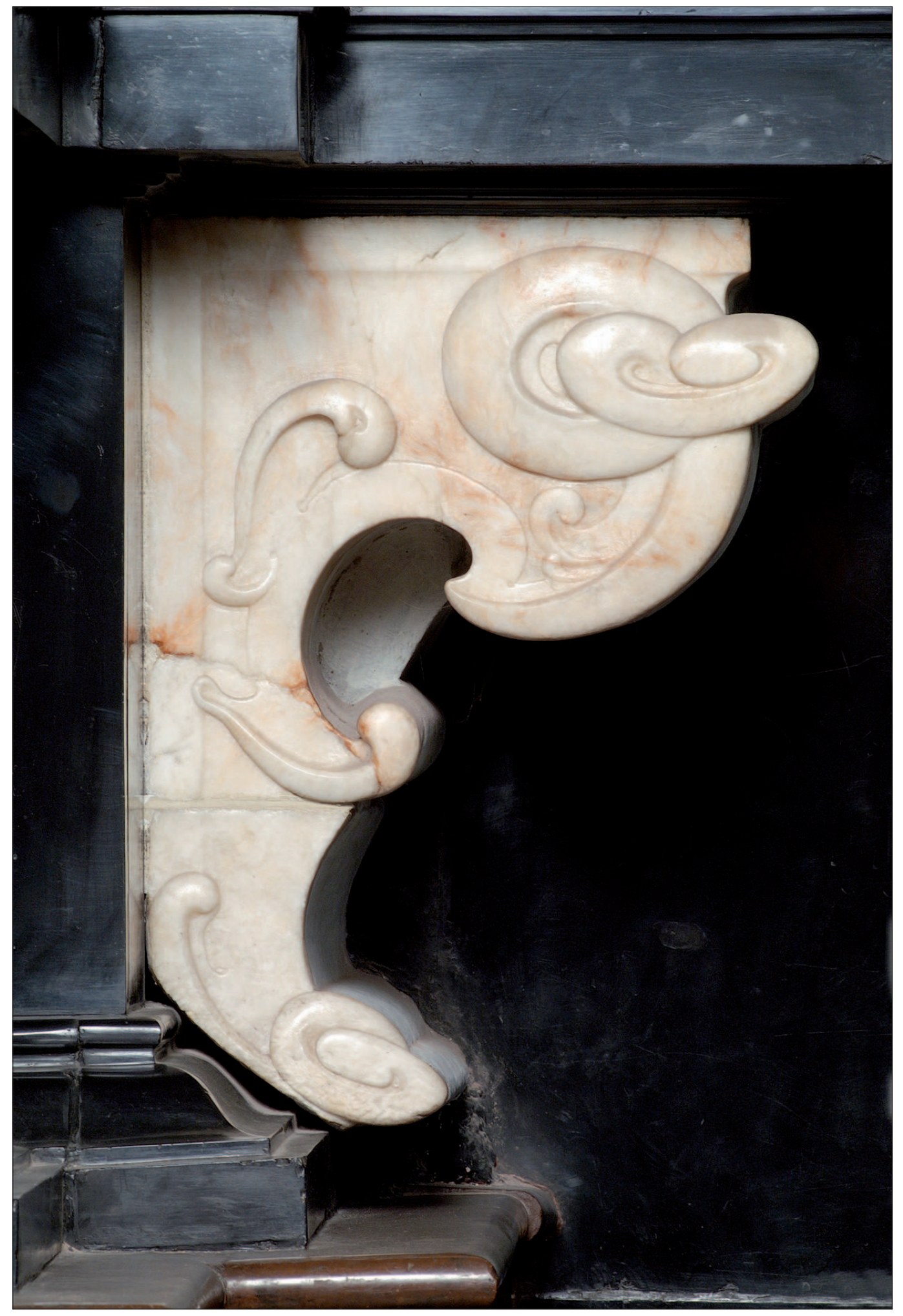

Il. 23. Konsolka alabastrowa pod uszakiem ołtarza w kaplicy Kołudzkich (fot. A. Skowroński) 


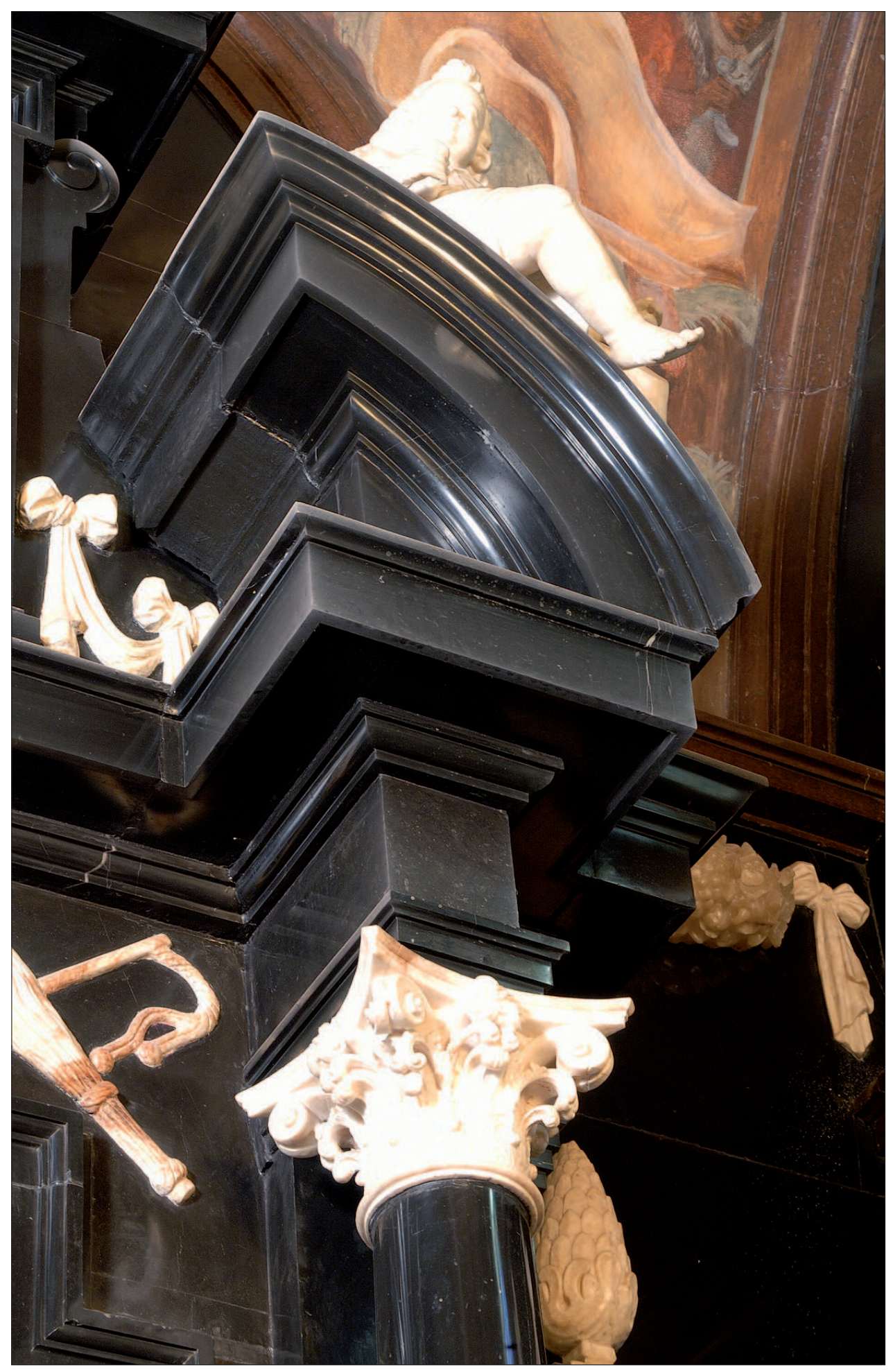

Il. 24. Kapitel i fragment belkowania ołtarza w kaplicy Kołudzkich (fot. A. Skowroński) 


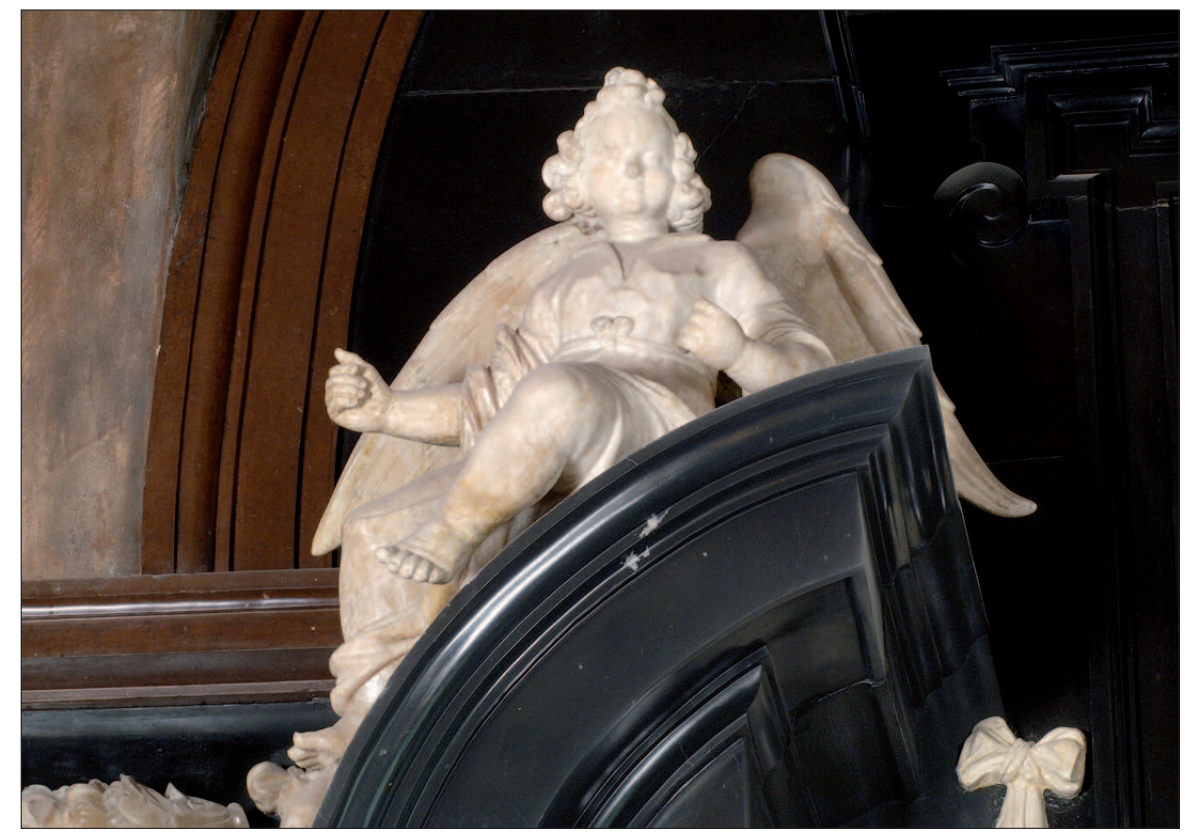

Il. 25. Anioł z lewej części rozerwanego naczółka ołtarza w kaplicy Kołudzkich (fot. A. Skowroński)

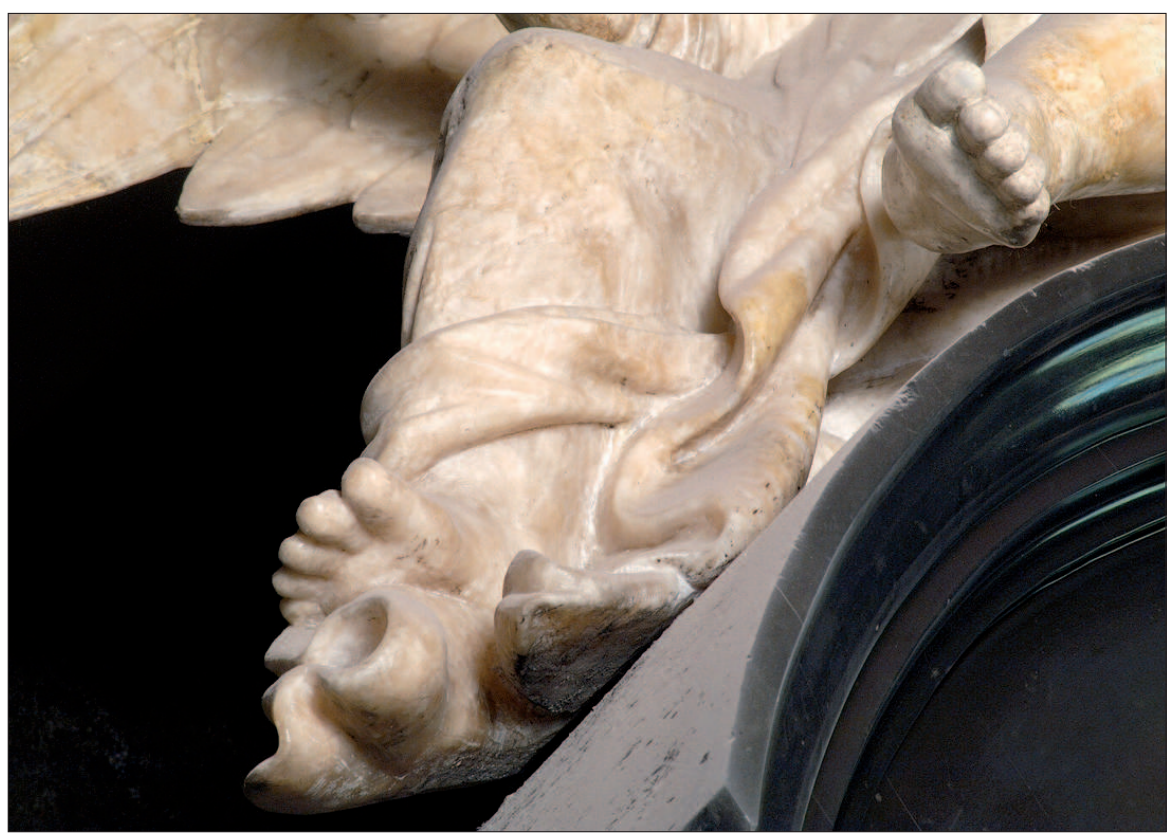

Il. 26. Anioł z lewej cześci rozerwanego naczółka ołtarza w kaplicy Kołudzkich, fragment. Skrzydło częściowo rekonstruowane (fot. A. Skowroński) 
a)

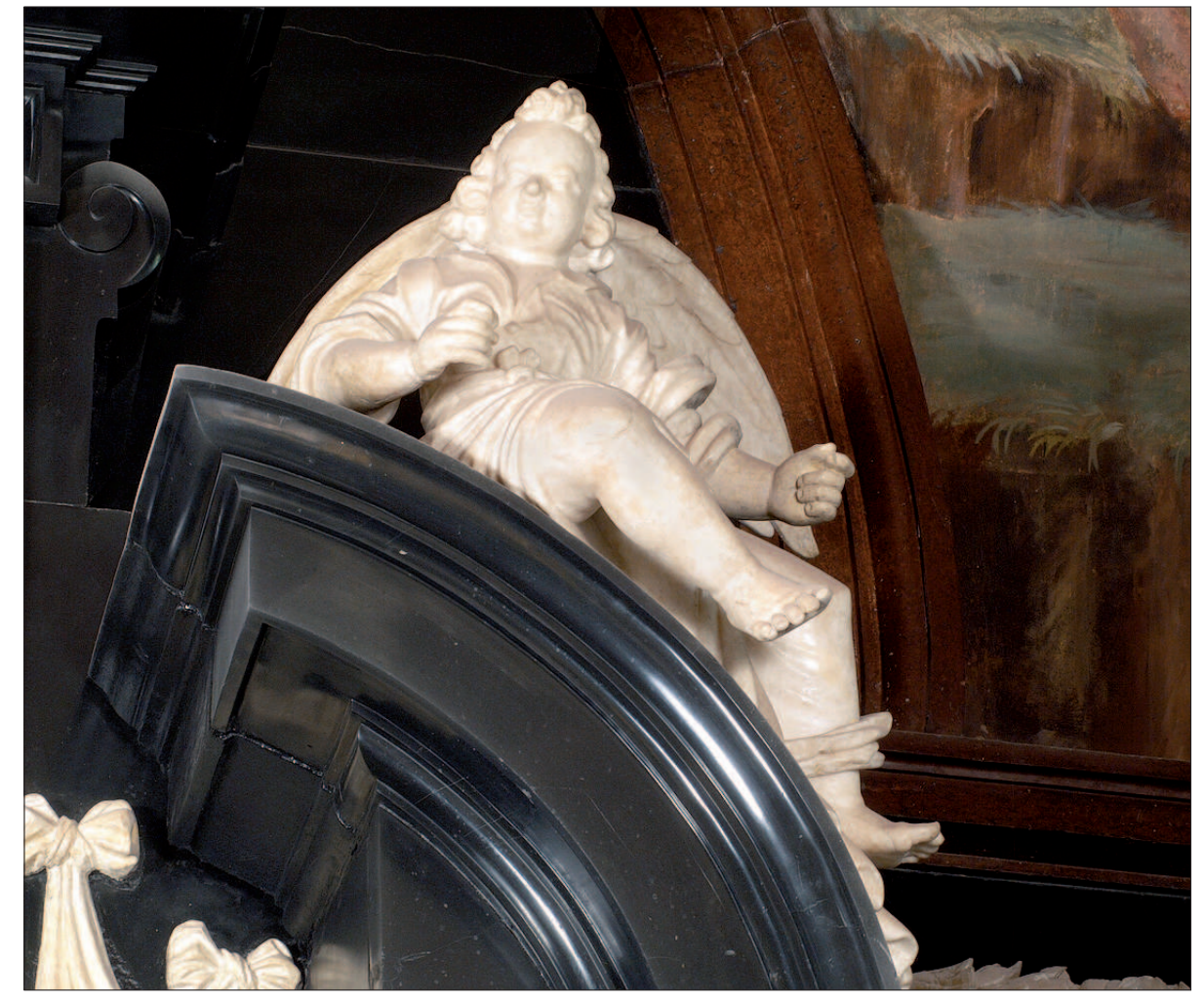

b)

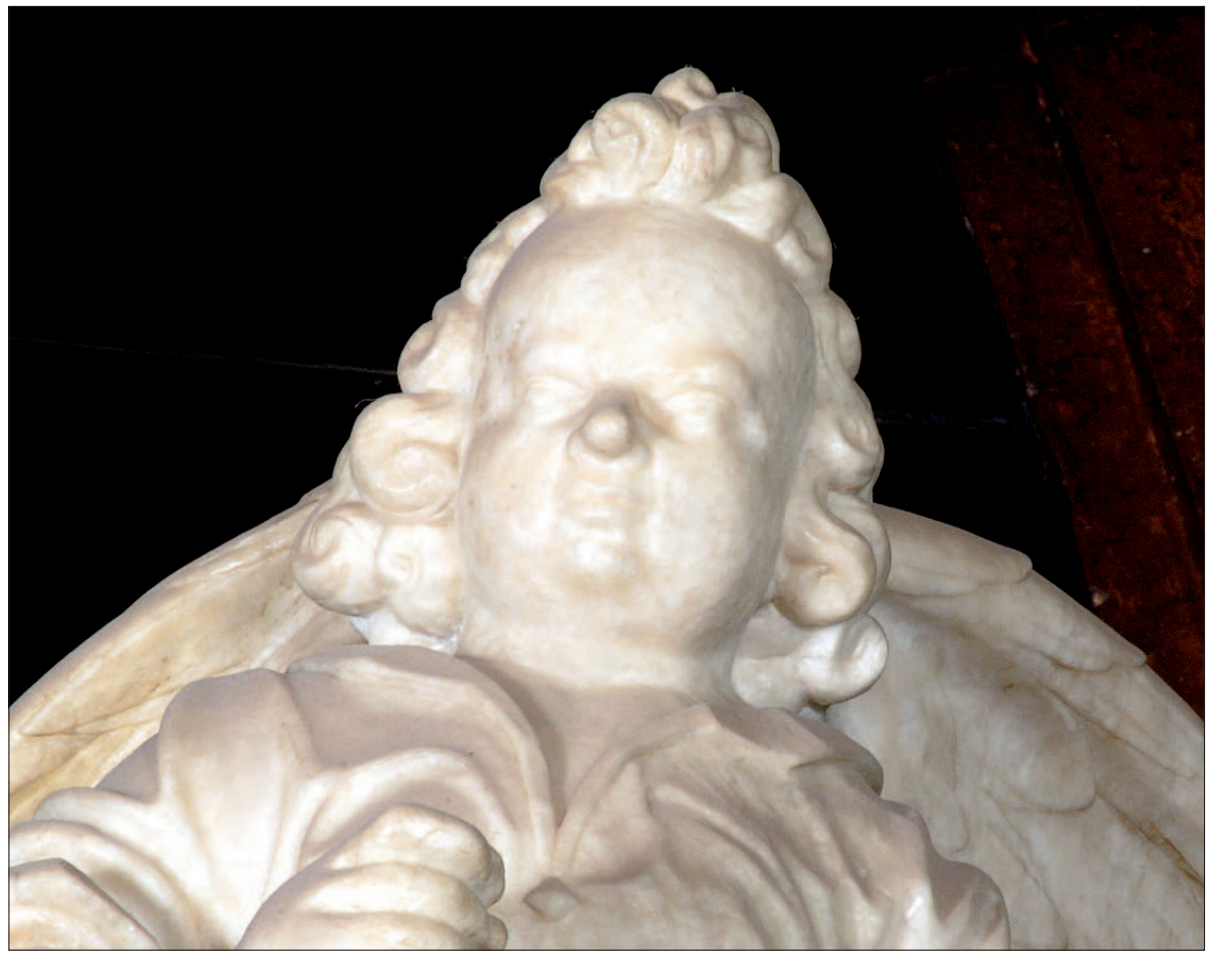

Il. 27a i b. Anioł z prawej cześci rozerwanego naczółka ołtarza w kaplicy Kołudzkich (fot. A. Skowroński) 


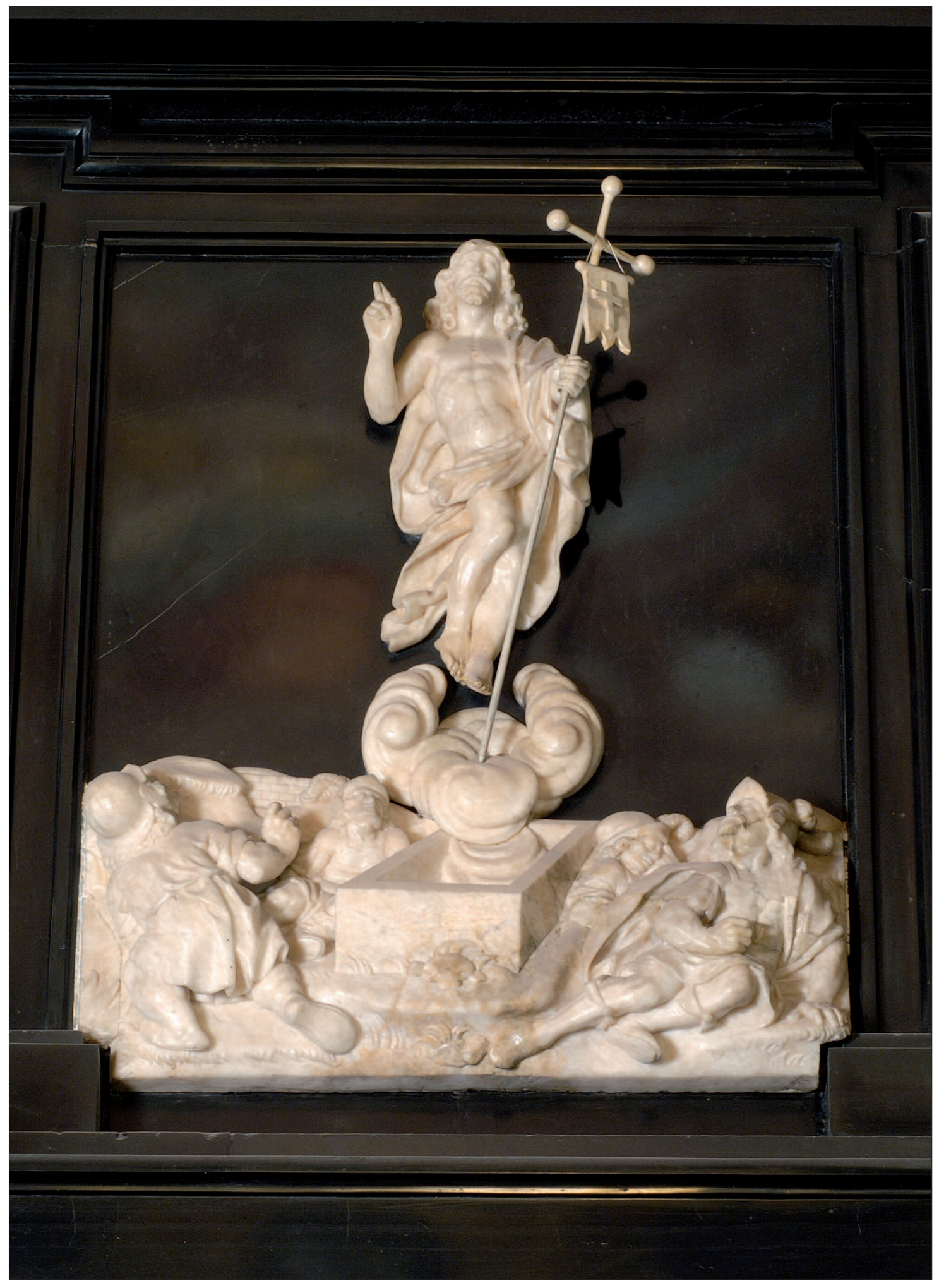

Il. 28. Grupa rzeźbiarska Chrystusa zmartwychwstałego w ołtarzu w kaplicy Kołudzkich (fot. A. Skowroński) 


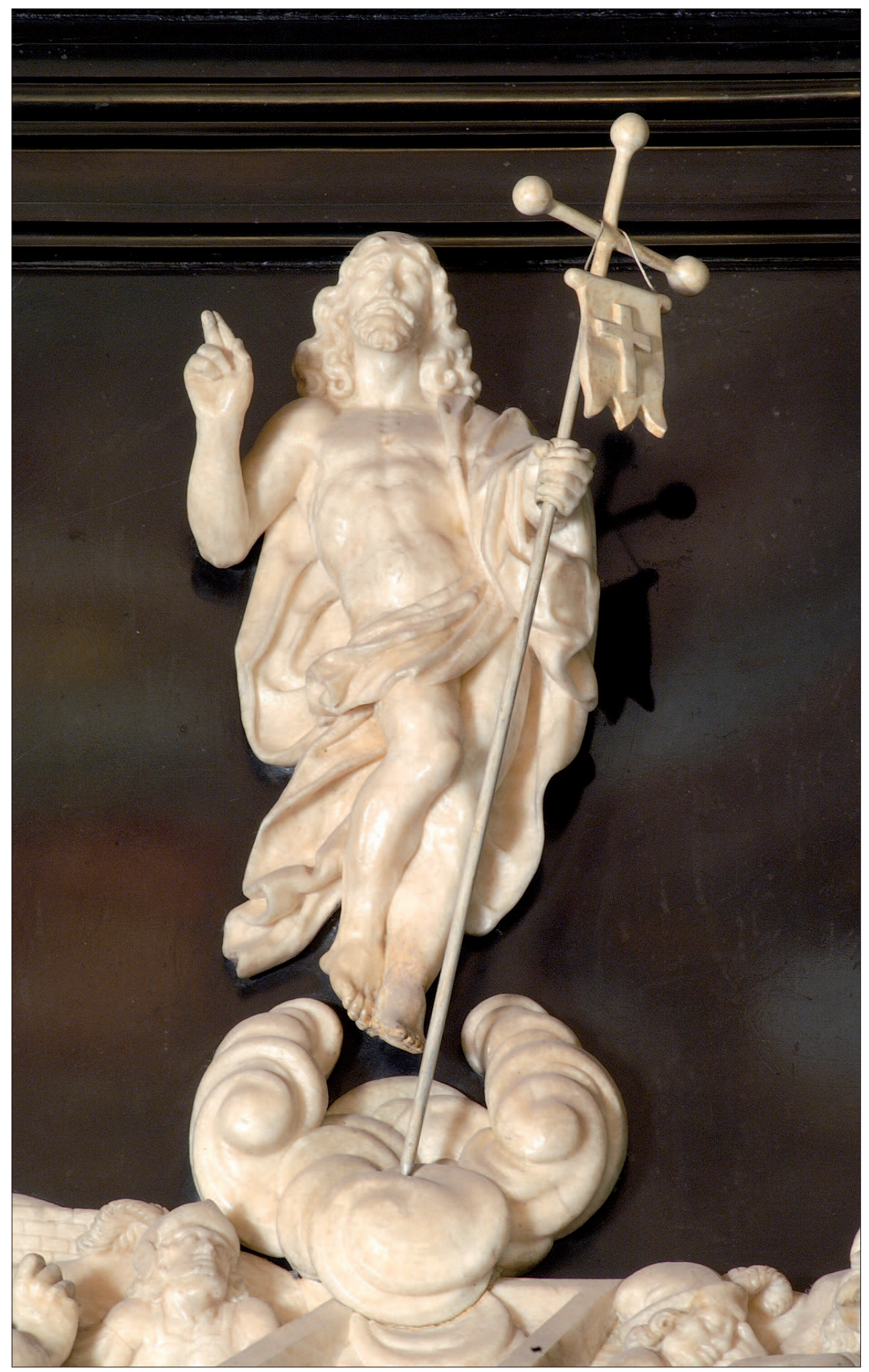

Il. 29. Grupa rzeźbiarska Chrystusa zmartwychwstałego w ołtarzu w kaplicy Kołudzkich, fragment (fot. A. Skowroński) 


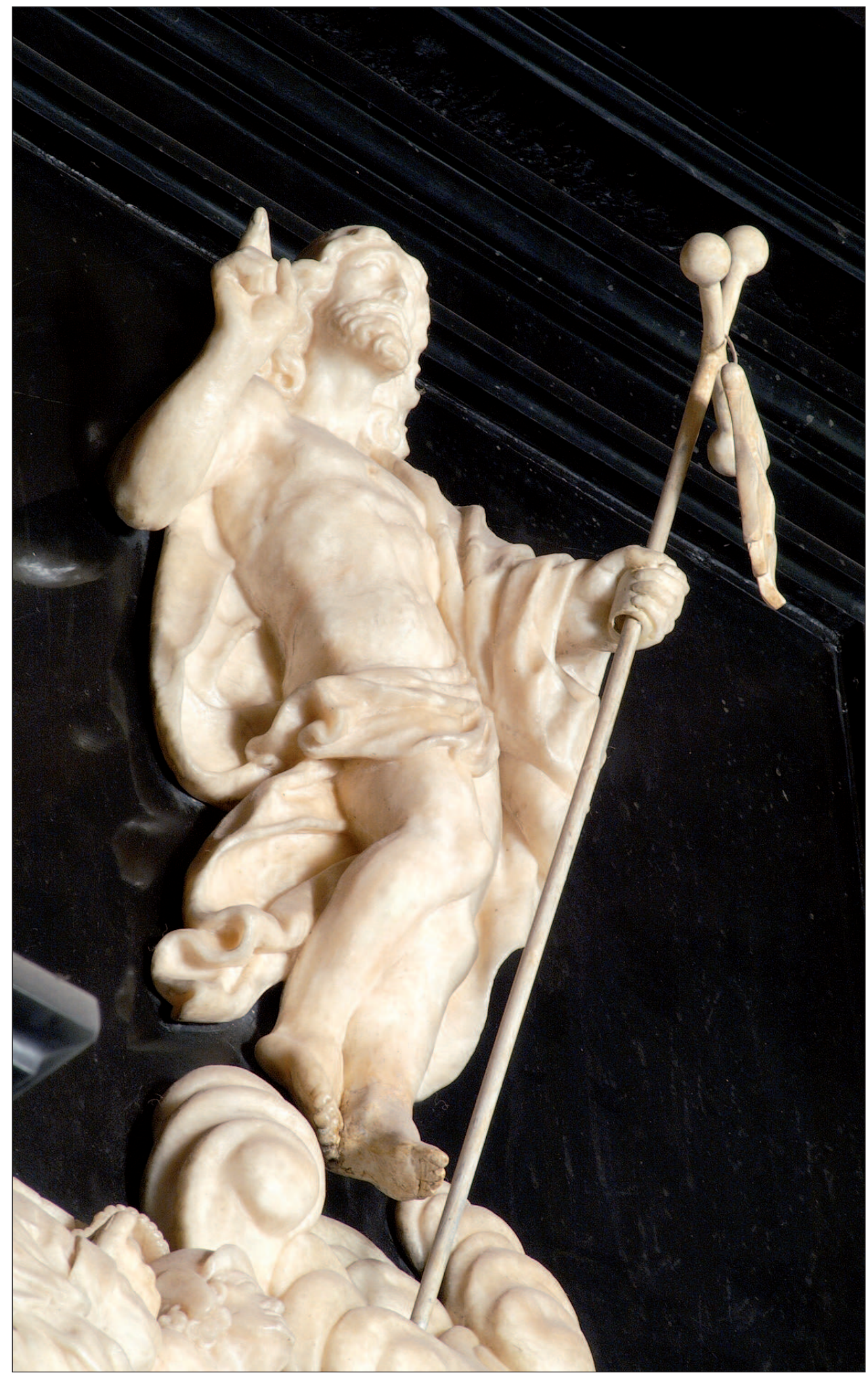

Il. 30. Grupa rzeźbiarska Chrystusa zmartwychwstałego w ołtarzu w kaplicy Kołudzkich, fragment (fot. A. Skowroński) 


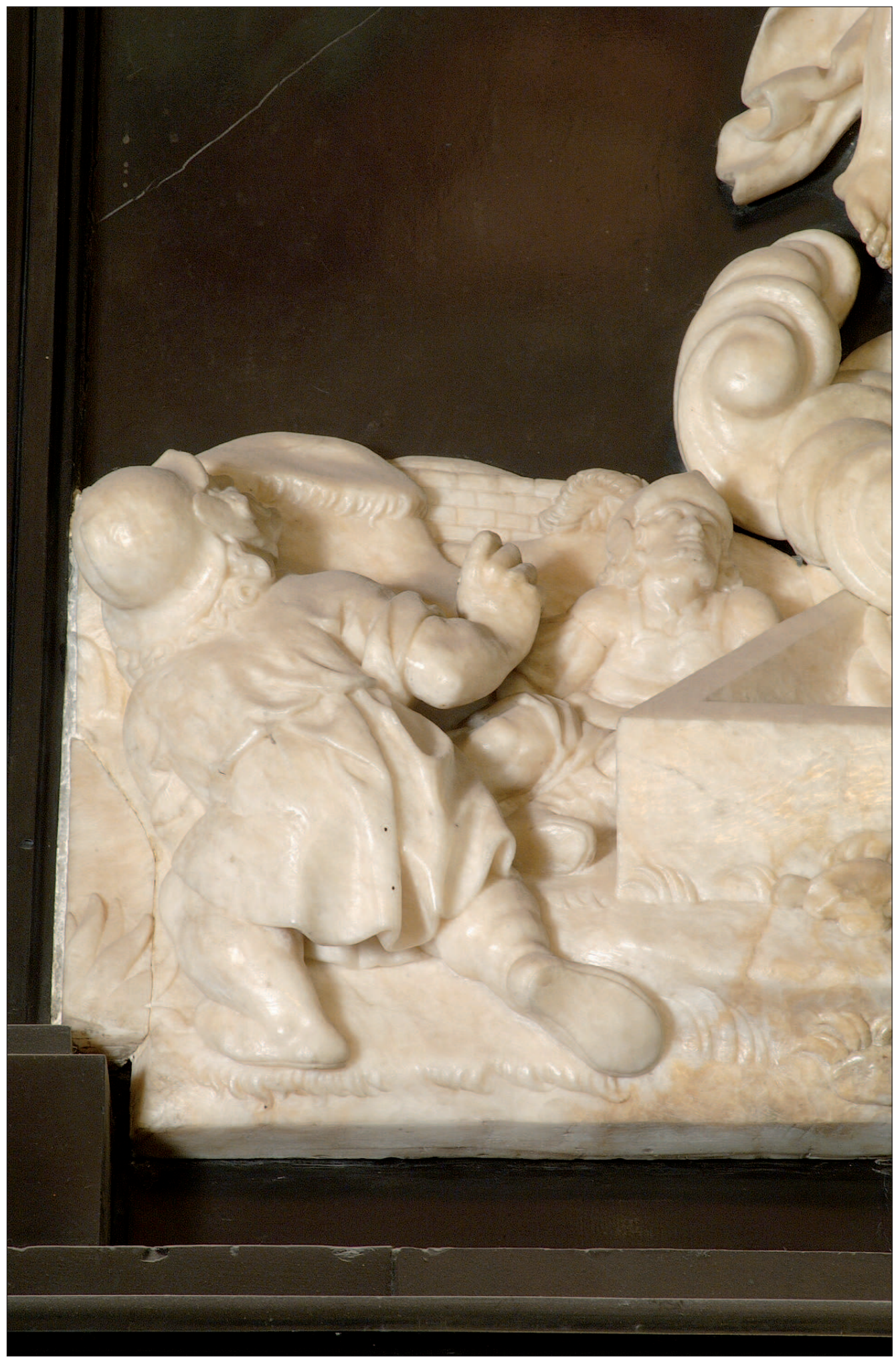

Il. 31. Grupa rzeźbiarska Chrystusa zmartwychwstałego w ołtarzu w kaplicy Kołudzkich, fragment (fot. A. Skowroński) 


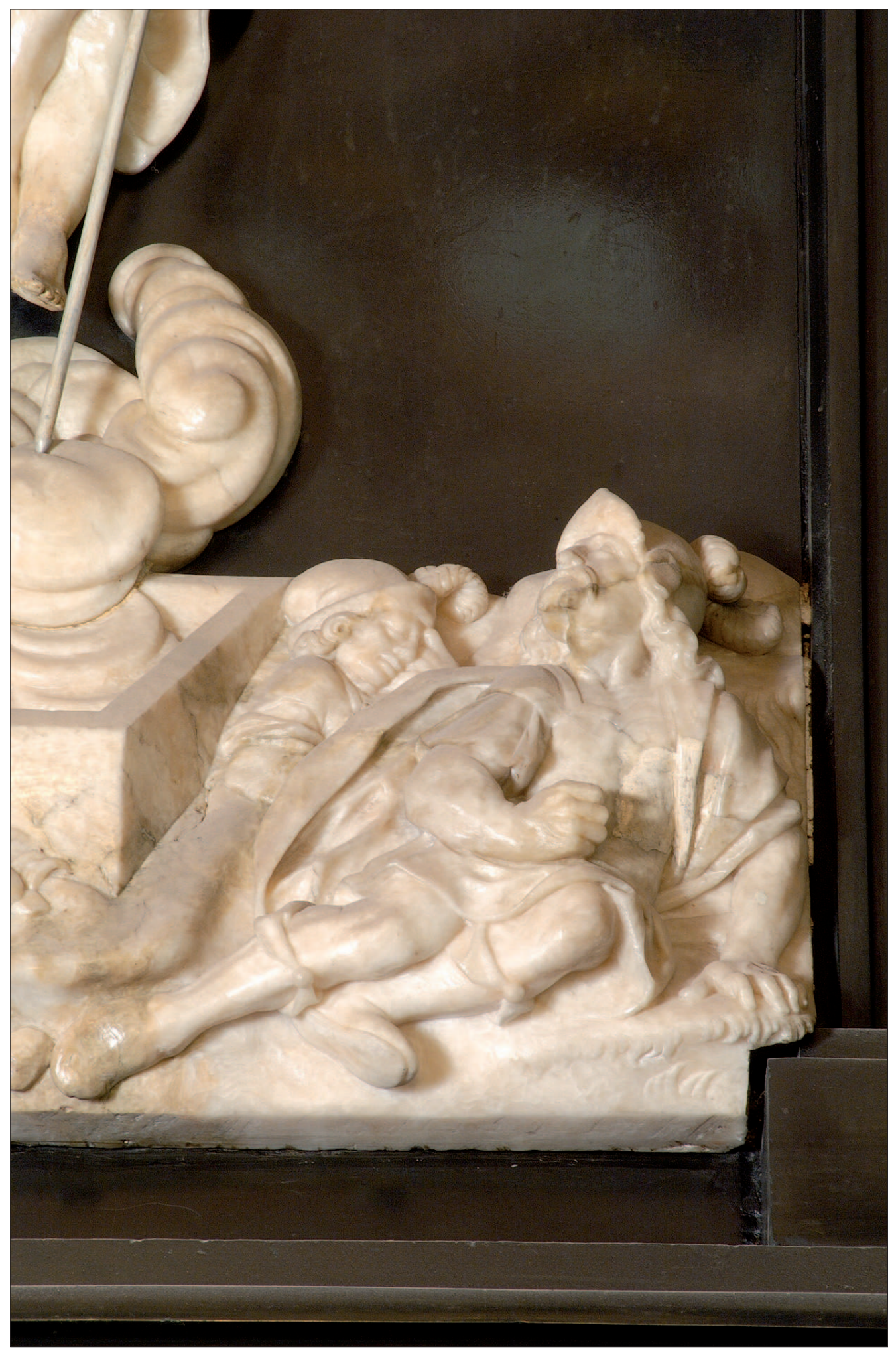

Il. 32. Grupa rzeźbiarska Chrystusa zmartwychwstałego w ołtarzu w kaplicy Kołudzkich, fragment (fot. A. Skowroński) 


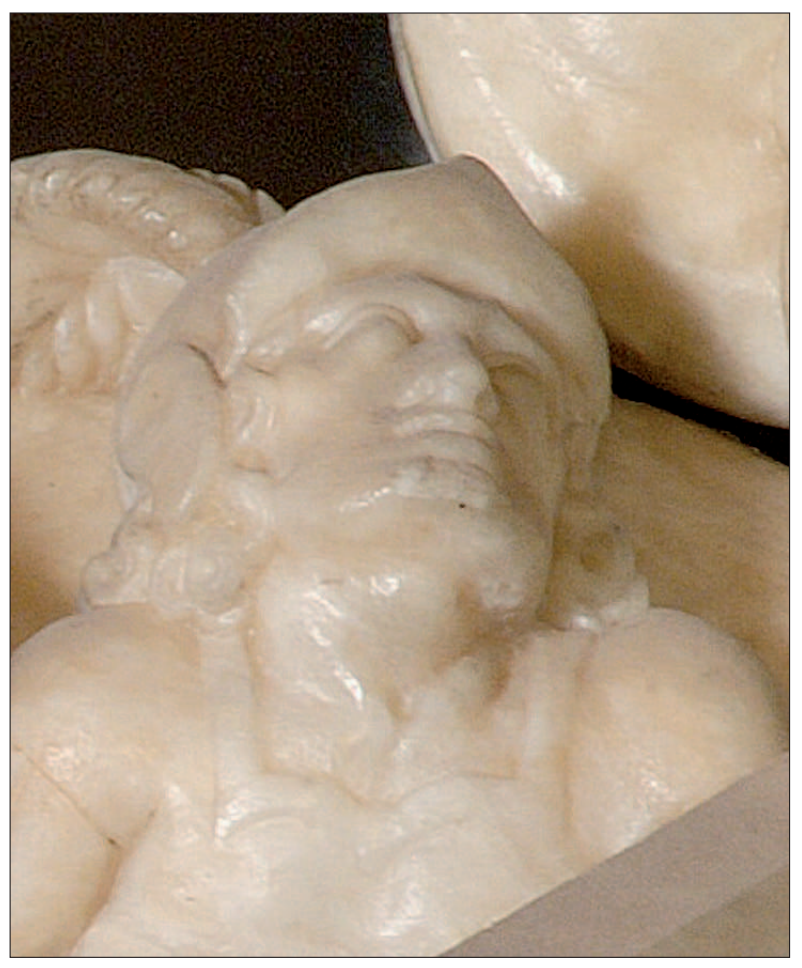

I1. 33. Grupa rzeźbiarska

Chrystusa zmartwychwstałego w ołtarzu w kaplicy Kołudzkich, fragment (fot. A. Skowroński)

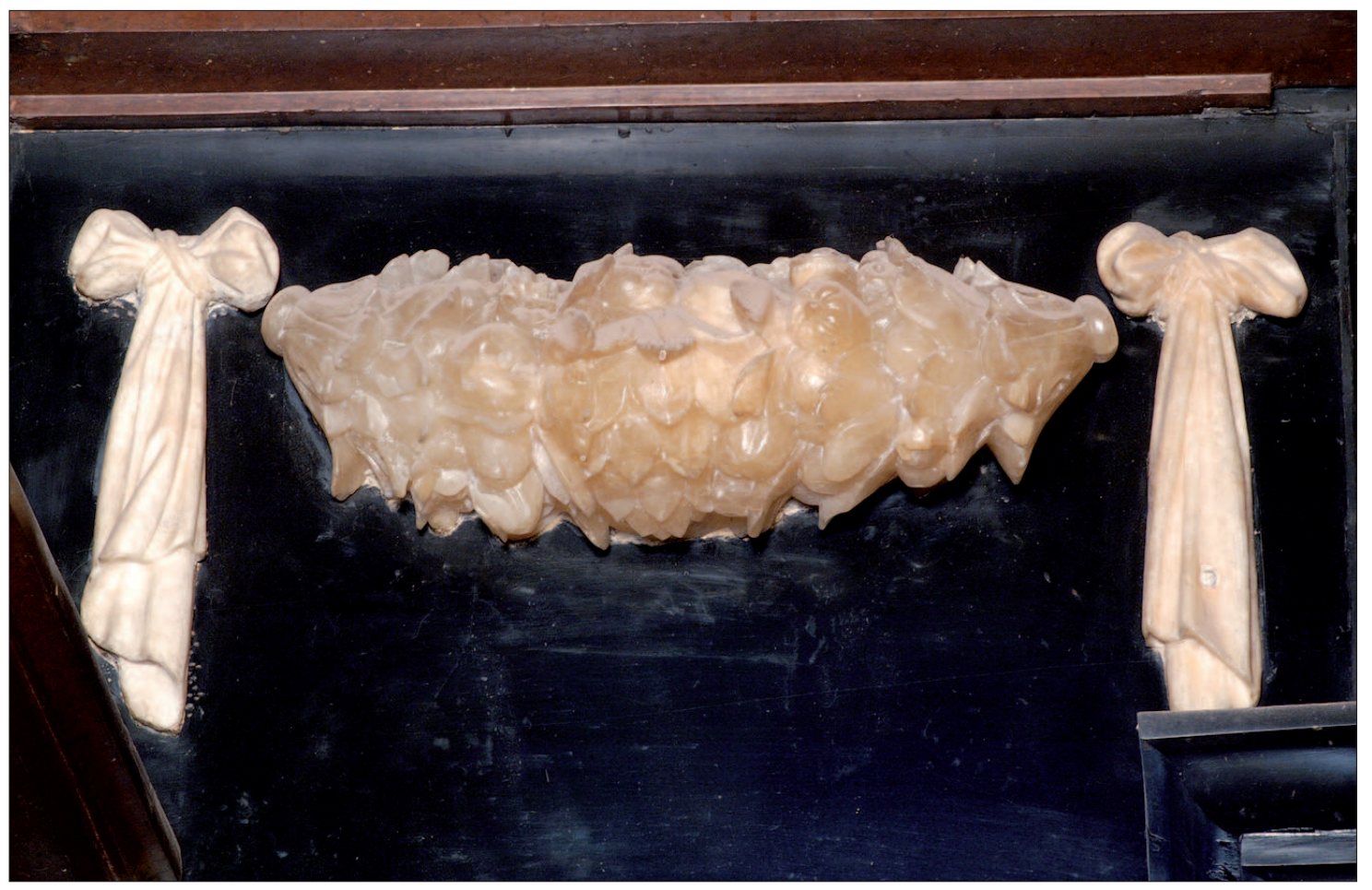

Il. 34. Alabastrowa girlanda owocowo-listna na ścianie ołtarzowej w kaplicy Kołudzkich (fot. A. Skowroński) 


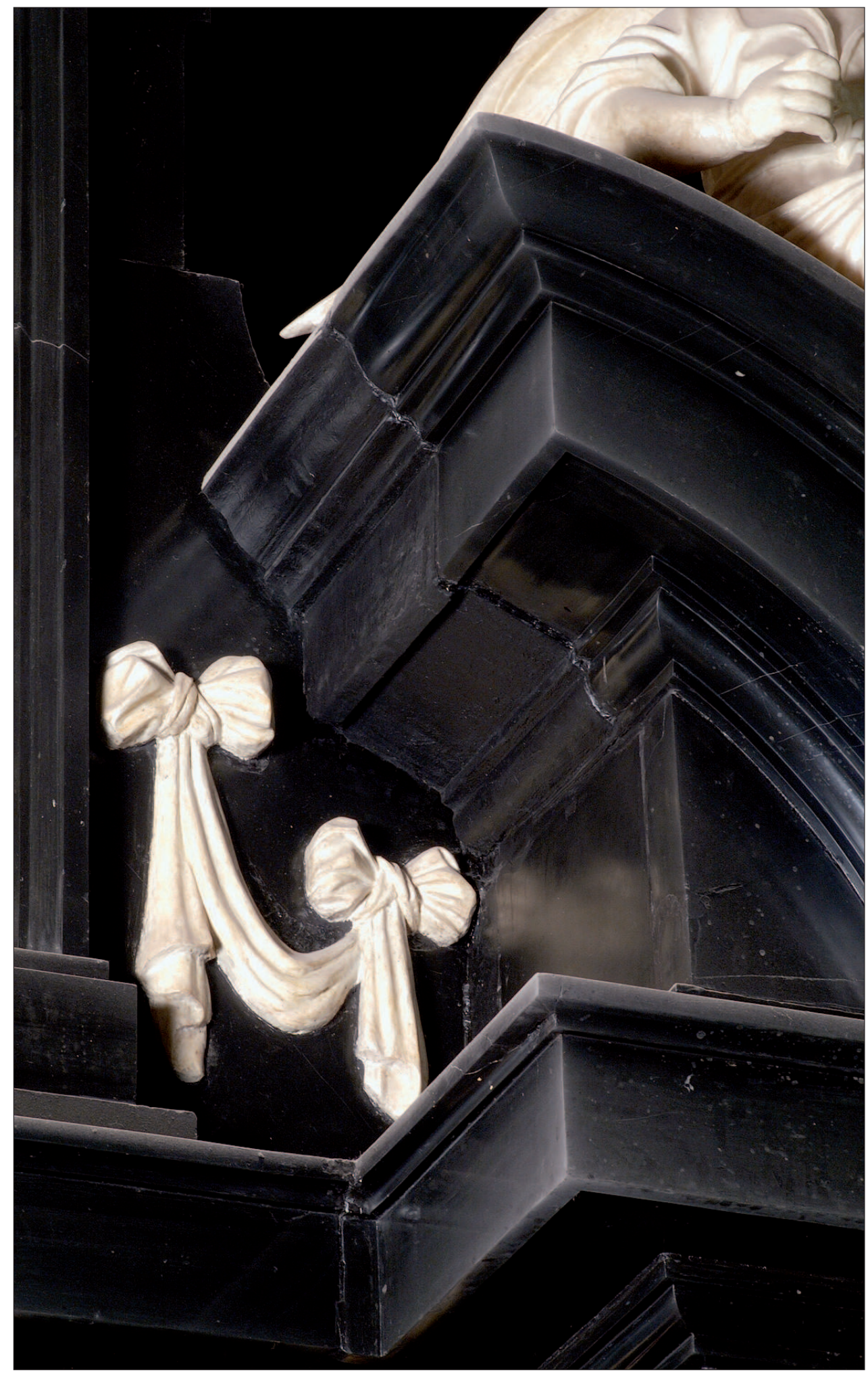

Il. 35. Fragment naczółka ołtarza w kaplicy Kołudzkich. Widoczna chusta rekonstruowana, wykonana z gipsu (fot. A. Skowroński) 
[80]

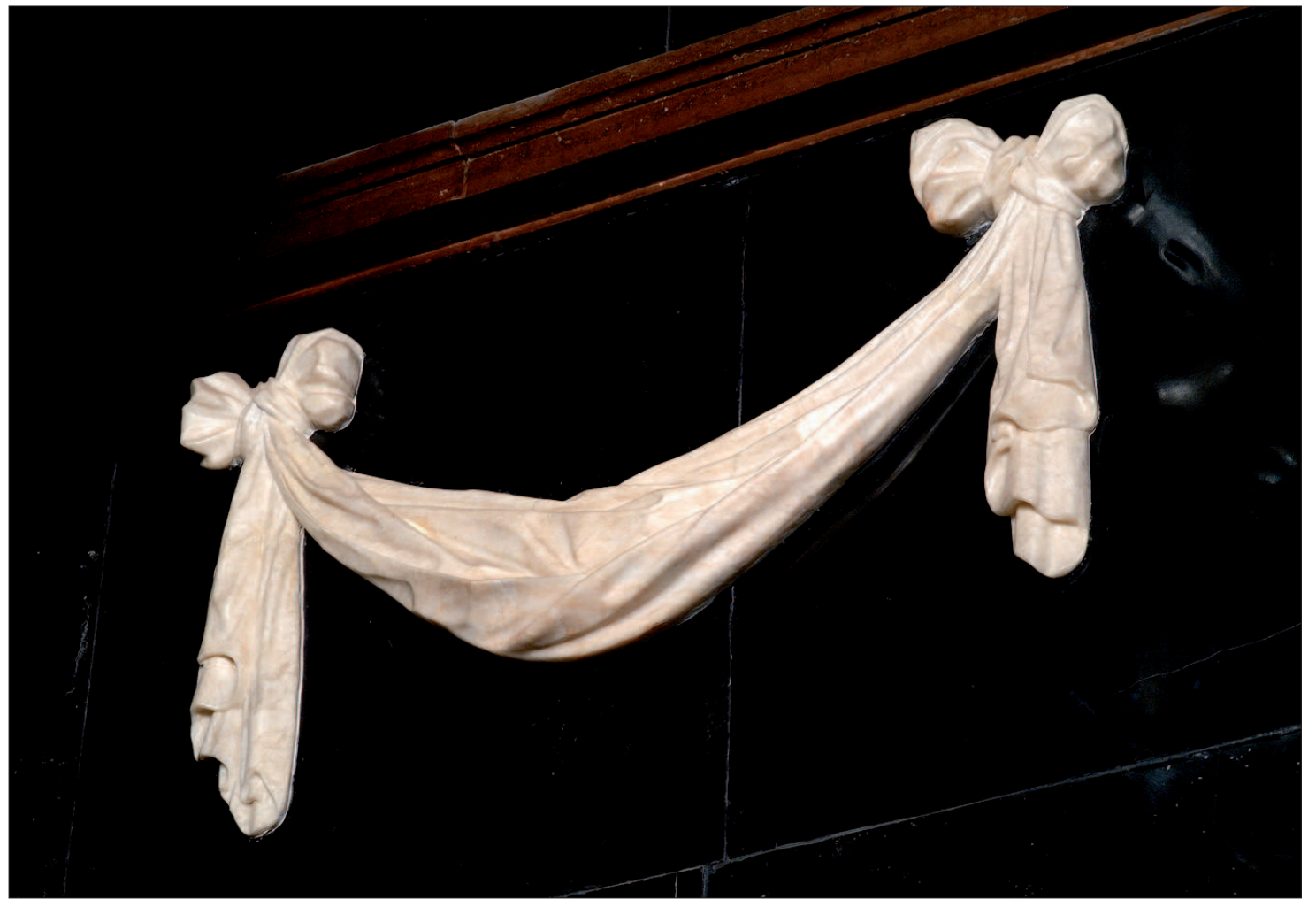

Il. 36. Alabastrowa chusta na ścianie w kaplicy Kołudzkich (fot. A. Skowroński)

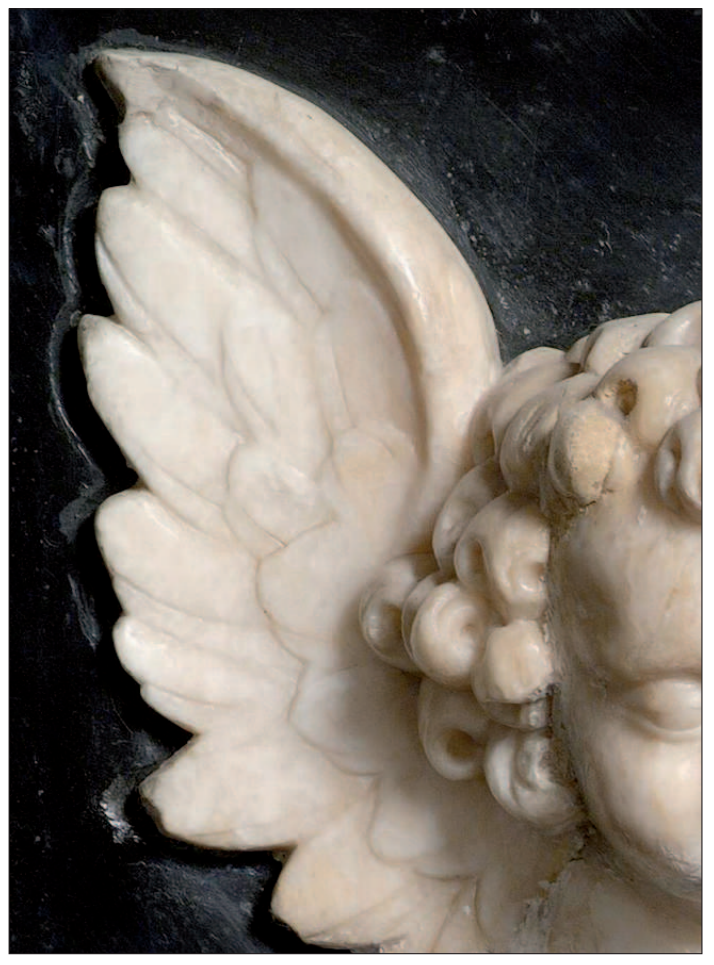

Il. 37. Wyryte w czarnym marmurze kształty przyszłej dekoracji (fot. A. Skowroński) 


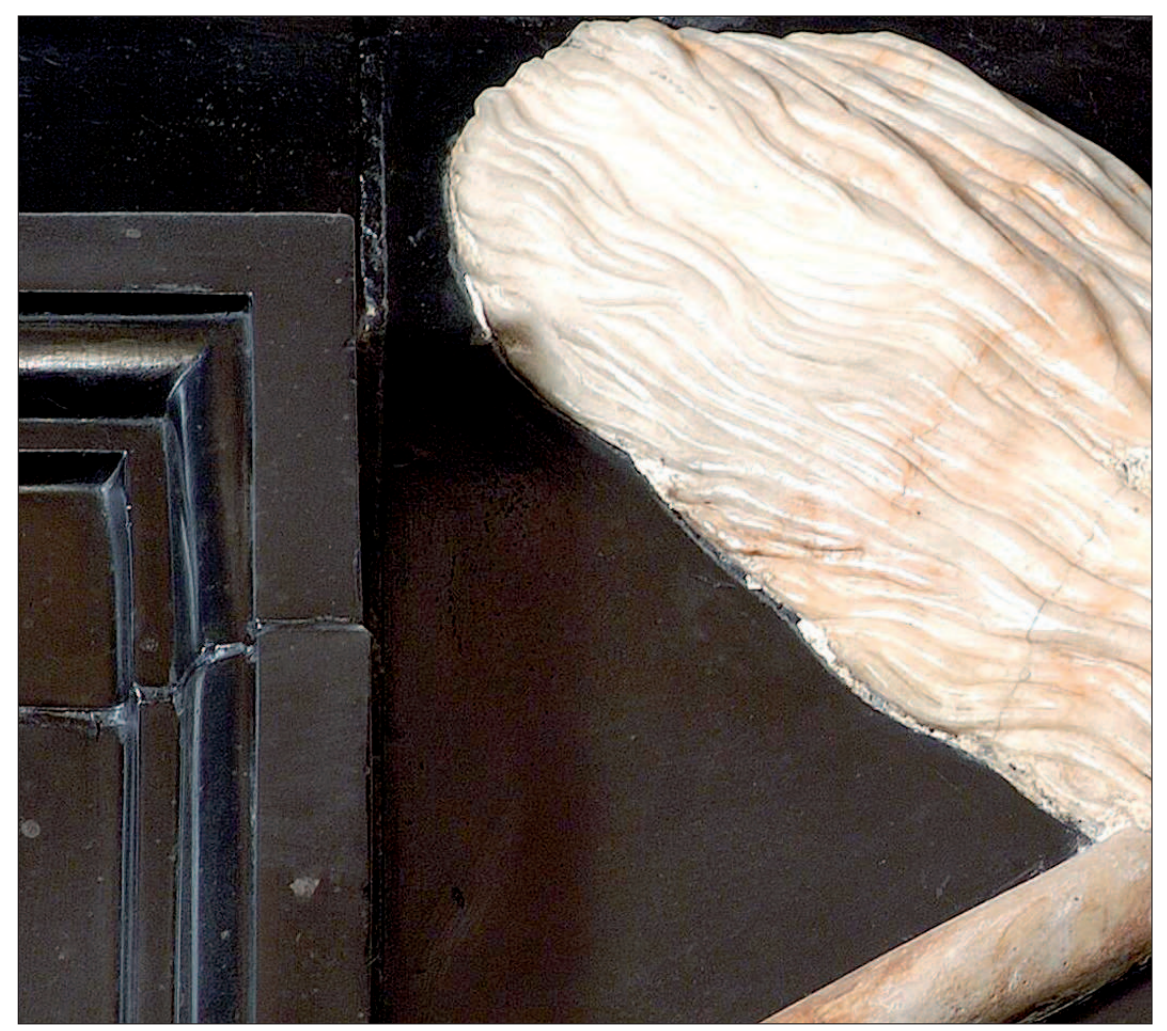

Il. 38. Przykład nieprecyzyjnego spasowania pionowych profilowań (fot. A. Skowroński)

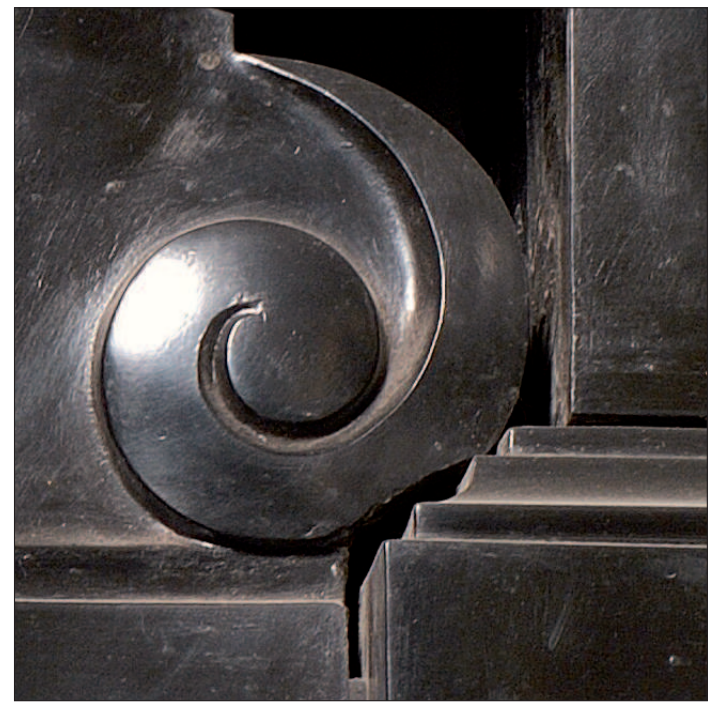

I1. 39. Podpiłowana woluta ołtarza w kaplicy Kołudzkich. Ślad problemów z montażem (fot. A. Skowroński)

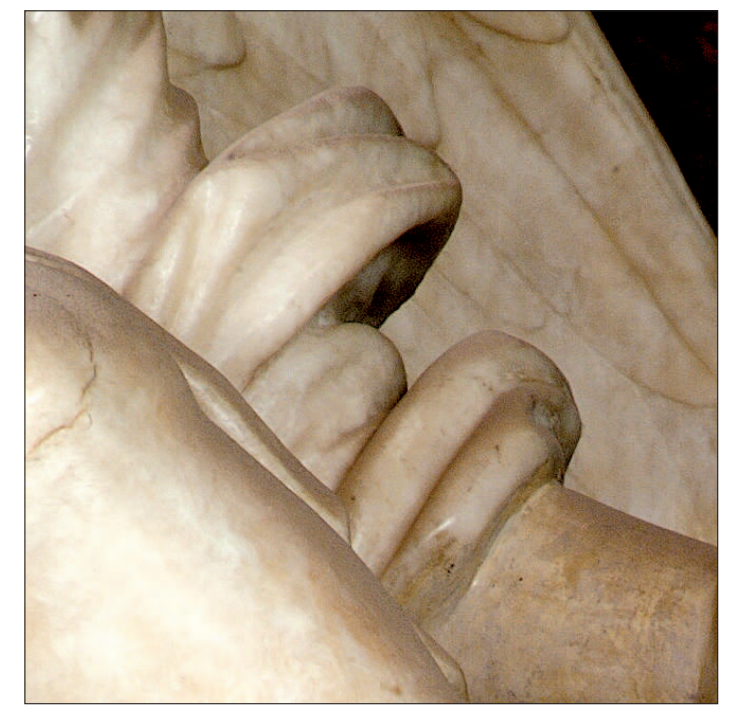

Il. 40. Fragment ręki anioła $z$ prawej części naczółka ołtarza w kaplicy Kołudzkich (fot. A. Skowroński) 


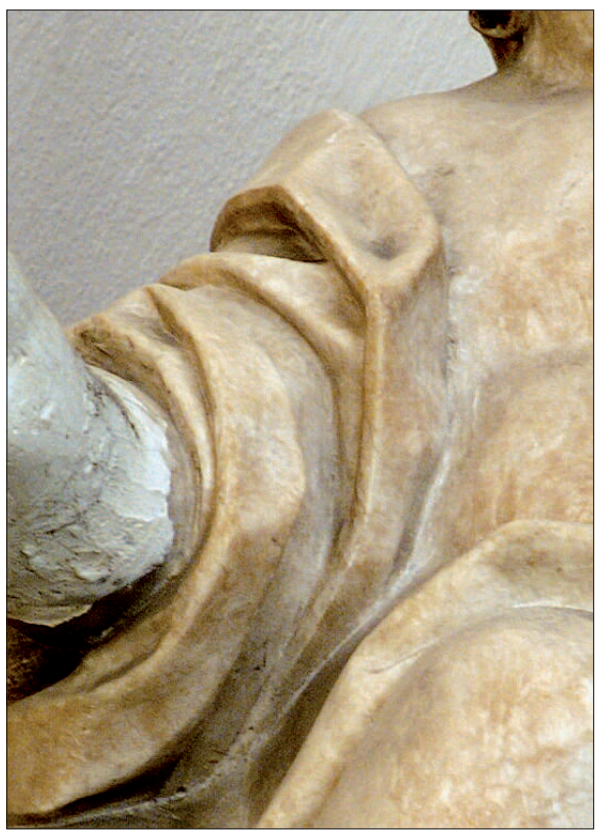

Il. 41. Fragment putta z lewej strony zwieńczenia portalu w kaplicy

Kołudzkich, po 1647 r., przed 1652 r. (fot. A. Skowroński)

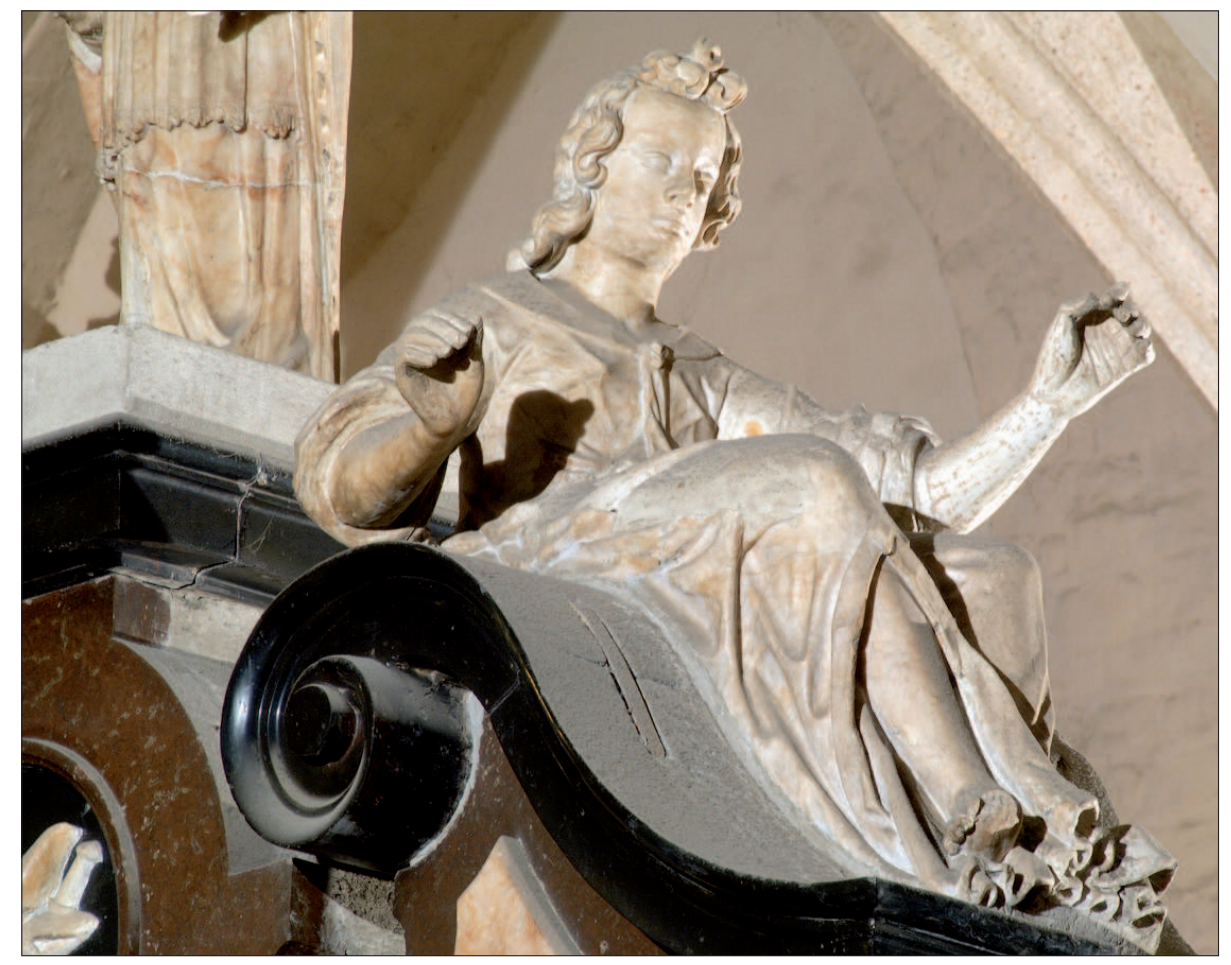

Il. 42. Postać z portalu po stronie północnej prezbiterium katedry w Gnieźnie o potwierdzonym źródłowo autorstwie Wilhelma Richtera, 1654 r. (fot. A. Skowroński) 


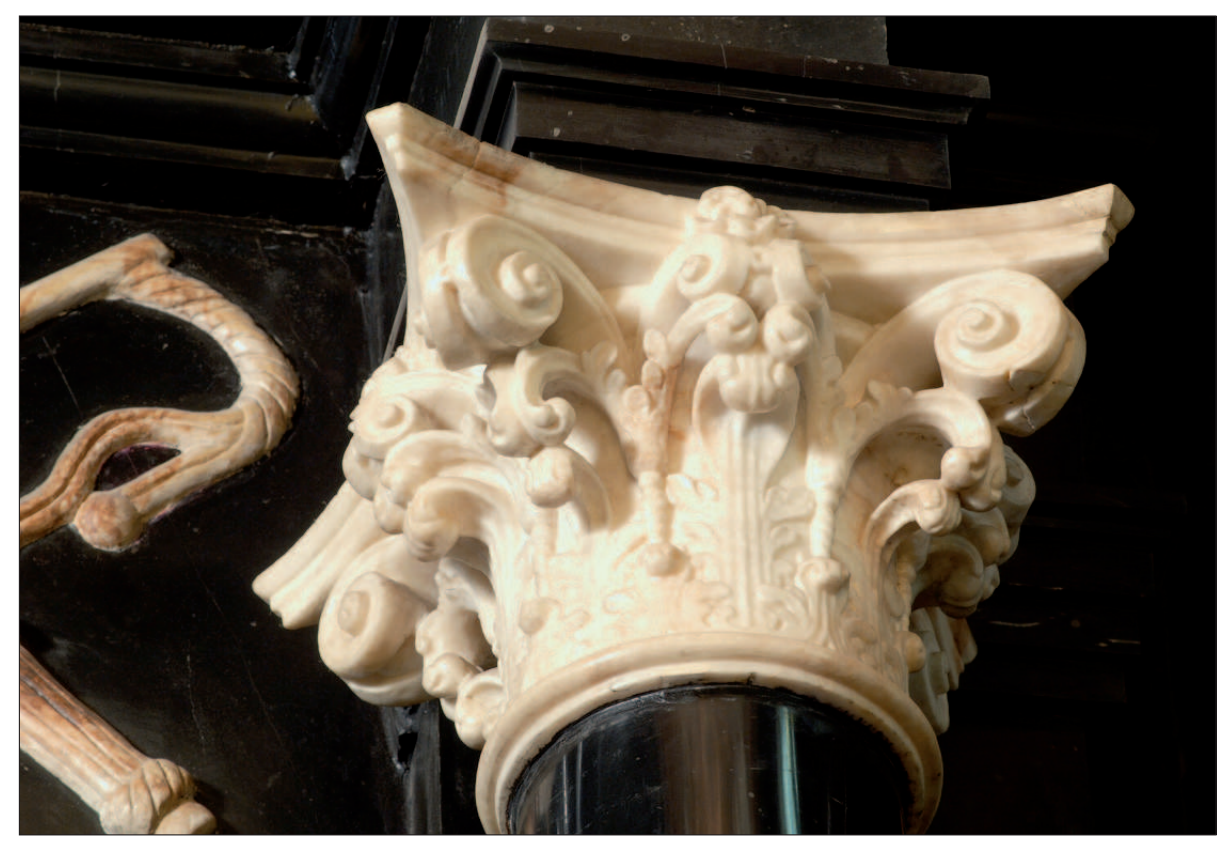

Il. 43. Kapitel kolumny w ołtarzu w kaplicy Kołudzkich (fot. A. Skowroński)

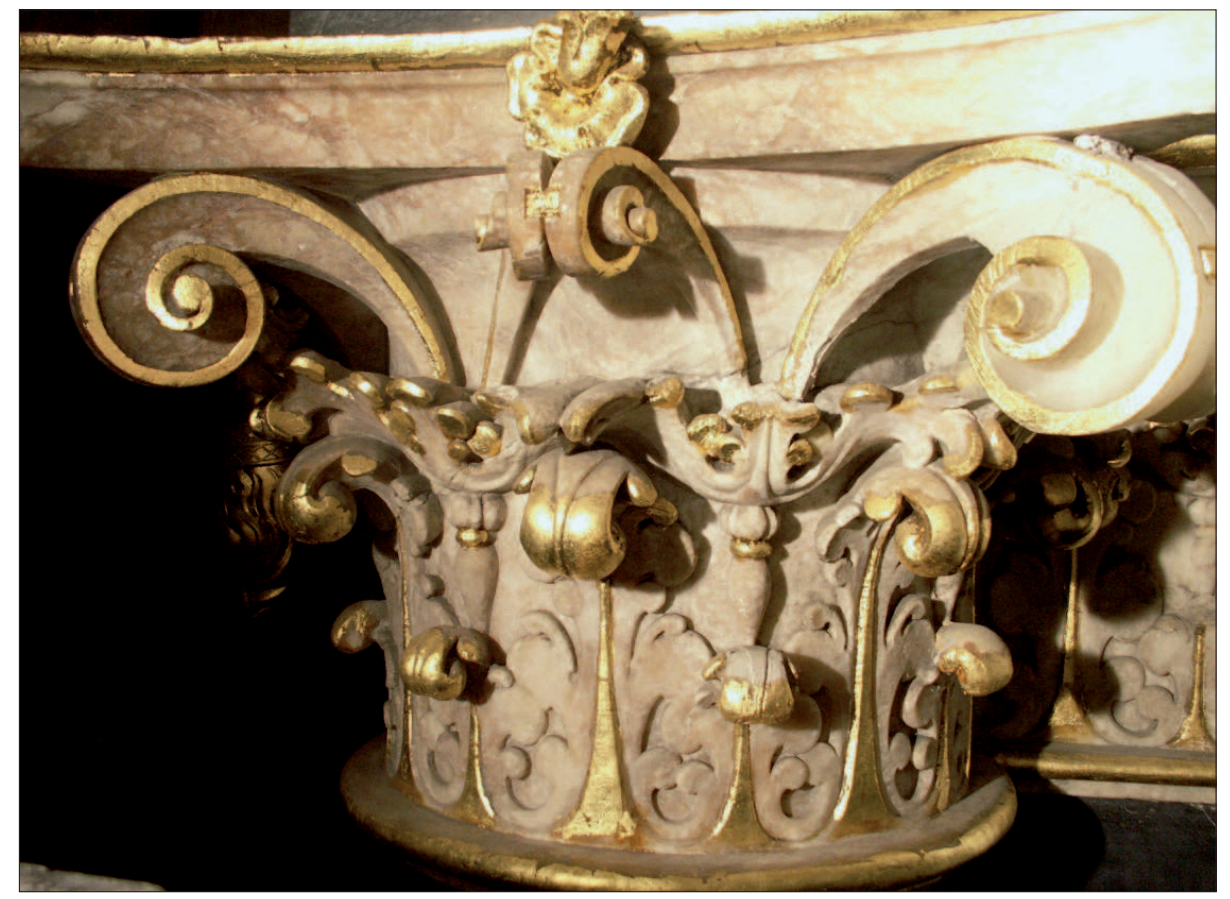

Il. 44. Kapitel kolumny w portalu pomnika grobowego Anny Wazówny w kościele Wniebowzięcia Najświętszej Panny Marii w Toruniu, ok. 1636 r. (fot. M. Rdesińska, A. Saar-Kozłowska) 

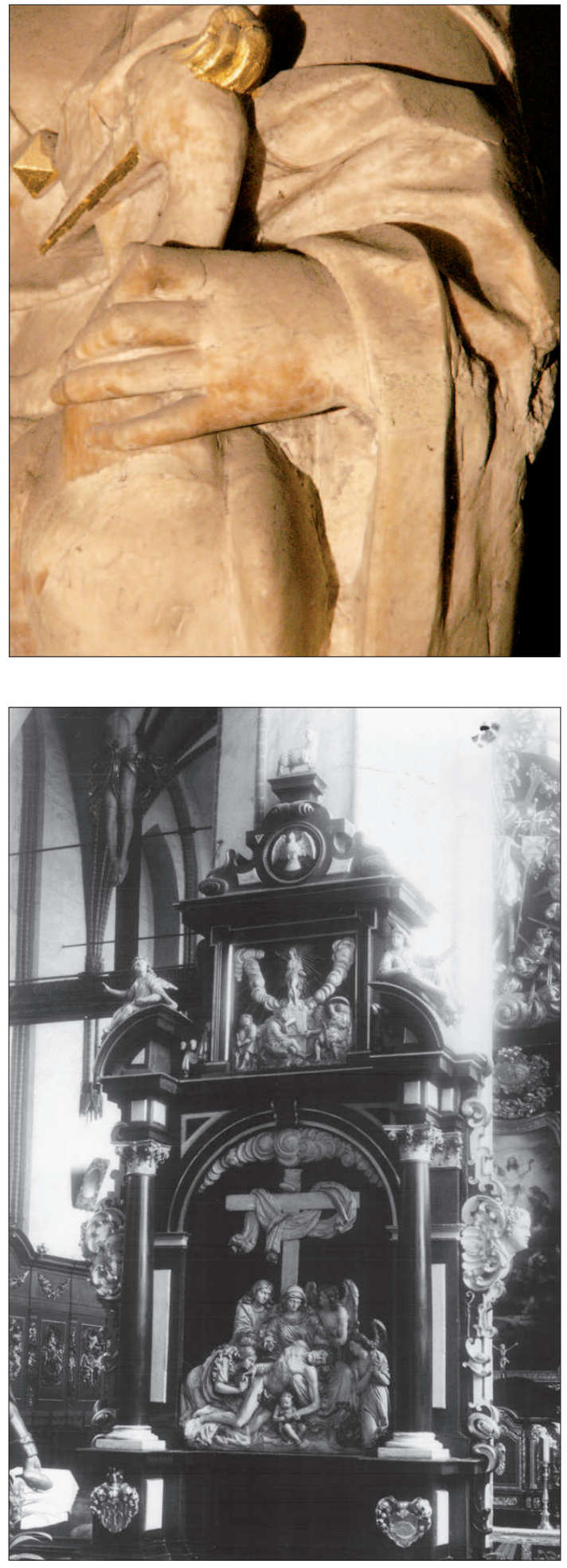

Il. 46. Ołtarz Opłakiwania z kościoła św. Mikołaja w Gdańsku (fot. J. Pałubicki)
Il. 45. Fragment figury po lewej stronie portalu pomnika grobowego Anny Wazówny, ok. 1636 r. Widoczny sposób rzeźbiarskiego opracowania niewidocznych partii rzeźby po prawej stronie oraz złączonego z podłożem czubka bocianiego dzioba (fot. M. Rdesińska, A. Saar-Kozłowska)

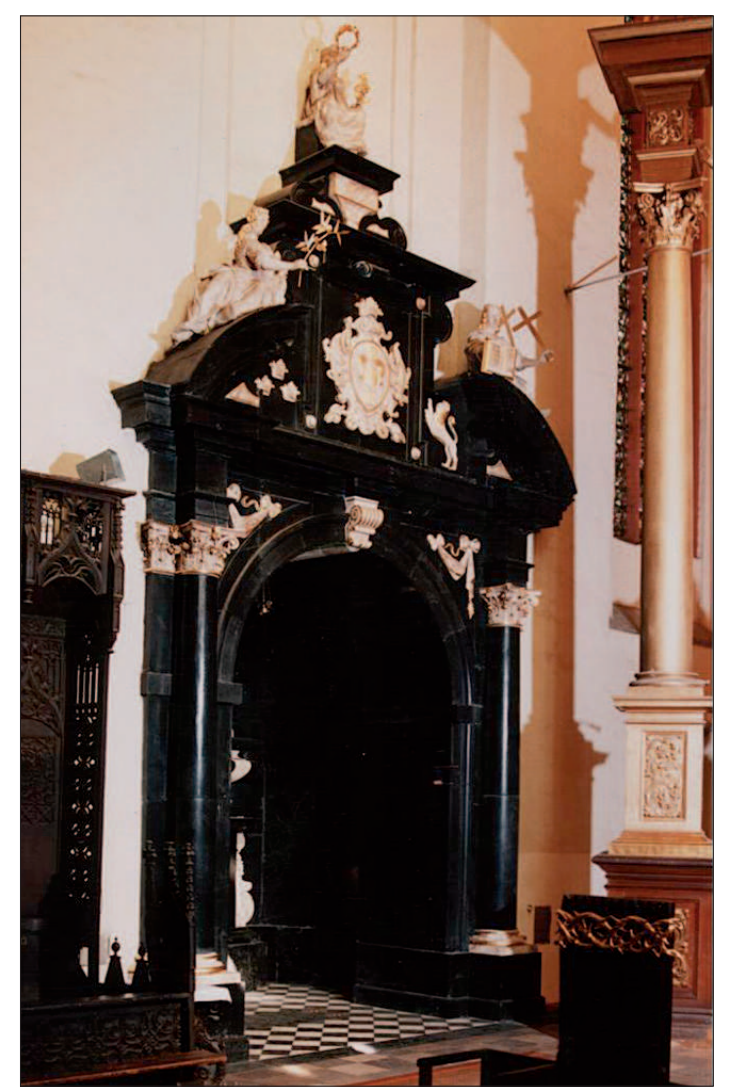

Il. 47. Portal pomnika grobowego Anny Wazówny, ok. 1636 r. (fot. A. Skowroński, W. Górski) 


\section{Summary}

\section{The problem of attribution of architectural and sculpted furnishing of the Kołudzki family chapel in Gniezno cathedral} The attempt to identify the workshop features

The attribution of monuments of Polish sculpture of $17^{\text {th }}$ century, among them the Kołudzki family chapel, makes a serious issue. It is been barely touched upon in the literature and scarcely illustrated. The attribution of decoration of the chapel and the portal leading to its interior has not been confirmed by the sources. It has been attributed to two leading personalities of the art of sculpture on Polish territory: Sebastian Sala and Wilhelm Richter.

The characteristic feature of the workshop mounting the elements of the chapel interior was not so great precision, however the architectonic elements represent quite high level of workshop skills. The surface of sculptures had been finished in various ways or had reacted to destructive factors differently. In the set of sculptures and bas-reliefs one can notice distinct differences in the way and level of precision of cutting the stone and the skill of the chisel, finishing the shapes and forms, anatomical correctness and relation to the surrounding space.

The figures of apostles had been chiselled to soft, streamlined forms, and create the impression of being created by a hand accustomed to working in material softer, than stone. Particular forms fluently flow one into another and there in no precise division lines. The sculpture does not much interact with the surrounding space. Some effort had been made to individualise the faces. Similar softness of finish, with a tendency towards imprecise cutting can be noticed in the figure of crucified Christ. His face expresses a drama, the body has been treated in a summary way, only the chest, more sculpted at the sides creates light-and shade effects.

The figures of little angels in the crowning seem to repeat the pattern once worked out in the workshop in versions dependent on the skills of particular sculptors. They characterise with clear imperfectness of form and its soft finish. They demonstrate the lowest artistic quality in the entire set of sculptures and basreliefs of the chapel furnishing. Place at the highest location, less visible, they have been left in more or less draft form. They are dominated by bulging, as if swollen 
shapes. Quite well rendered anatomy characterises the sculpture of crucified Christ, surely modelled after some painted or engraved pattern. The forms are chiselled quite softly, as if in a painter's manner, they seem liquid. In the group of soldiers surrounding the open grave their elaborate poses draw the attention as well as the suggestive rendering of the anatomy of musculature and perspective foreshortenings. Soft finish of forms characterise also the bas-relief of the vernicle as well as the winged heads of the putti.

The above remarks allow to make a statement, that in the works on architectural and sculpted furnishing of the Kołudzki family chapel participated different people, that characterised with diverse technical skills and uneven artistic level. Basing on the analysis of formal features of sculptures and bas-reliefs one can distinguish the input of diverse (three?) makers. One of them represents soft, pattern-like forms related with the shape of the used block of stone (mainly figures of the Apostles). The second is characterised with higher level of artistry, boldness of chiselling and anatomical correctness (the figure of crucified Christ). The third one liked to employ perspective foreshortenings and eagerly sculpted details of artefacts or musculature (soldiers of the Resurrection group). Sculpture of the portal reveals the hand of a master accustomed to shaping forms different, than those encountered in the interior of the chapel - rigid, boldly and precisely chiselled. Perhaps then it is worth asking the question: do one deals here with a multi-stage work with different masters and workshops employed? The answer is as follows: one rather deals here with one workshop and the activity of apprentices of diversified skills and abilities.

Any further conclusions as to the question of attribution of the chapel requires detailed formal analysis of the remaining monuments essential for such reckoning, such as the portal leading to the chapel, 4 other portals in the Gniezno cathedral that sources attribute to Richter; the works of Sala confirmed by sources (the tombstone of Opaliński family in Sieraków and the Oppensdorf family in Głogówek). The problem "Richter or Sala" still awaits its final solving. Also the dependences between the furnishing of the Kołudzki family chapel, the Mourning of Christ Retable in St. Nicholas Church in Gdańsk and Princess Anna Wasa memorial in Our Lady's Church in Torun in particular. One should pay attention to questions vital for the conducted research, that is to the workshop works' mode and the execution of masonry.

Both monuments reveal different way of execution of figural sculpture. The quality of Torun monument is much better, which may be the effect of employing 
a sculptor of special, higher skills to work on the royal foundation. However in both cases one can notice similar mode of working - careless treatment of less visible parts or leaving them entirely unfinished, as well as a specific treatment of smaller details of sculptures or those more exposed to destruction, that had not been entirely carved off the block of stone. The question that arises in this case is whether and to what extent the same workshop could have been employed to execute both monuments? Taking into consideration the similarity of architectonic structure of Torun portal (ca. 1636), the Gniezno Retable (before 1652) and the Mourning of Christ Retable in Gdańk (1662) one can risk a hypothesis, that the design prepared for Princess Wasa memorial in the circle of artists related with the royal court (Ghisleni?), has been exploited by the workshop working on its' execution also to execute the other two works mentioned above. However the further form the original model, the stronger manifested the features of Northern art. The very much probable answer to the question of what workshop has been subject of the analysis can be: one of the Gdańsk workshops, perhaps of Wilhelm Richter, which can be confirmed or excluded only by similarly conducted analyses based on a direct inspection of each monument and rich digital photographic documentation. 